\title{
Temporal Development and Regeneration Dynamics of Restored Urban
} Forests

\author{
By
}

Katherine de Silva

A thesis submitted to the Victoria University of Wellington in fulfilment of the requirements for the degree of Masters in Ecology \& Biodiversity

School of Biological Sciences

Faculty of Sciences

Victoria University of Wellington

October 2019 
Supervisors:

\section{Stephen Hartley.}

Director of the Centre of Biodiversity \& Restoration Ecology, Victoria University of Wellington

Kiri Joy Wallace.

Postdoctoral Fellow, Environmental Research Institute, University of Waikato.

Katherine de Silva: Temporal Development and Regeneration Dynamics of Restored Urban Forests, (C) October 2019. 
Urban forest restoration programmes are a key tool used to initiate, re-create or accelerate the succession of forest species; improving ecosystem services, function, resilience and biodiversity. Succession is a temporal shift in species dominance driven by abiotic and biotic influences, but over decadal timescales the trajectory and success of restoration plantings in degraded urban environments can be hindered. To facilitate the successful reconstruction of forest ecosystems from scratch, an understanding of the temporal patterns in planted forest development, dynamics of seedling regeneration and dominant drivers of seedling diversity is required.

Using a chronosequence approach, permanent plots were established at 44 restored urban forests aged 5 to 59 years since initial plantings took place, across five New Zealand cities between Wellington and Invercargill. Vegetation surveys were undertaken and data on microclimate were collected. This study examined the 1) temporal dynamics of restored urban forest development and seedling regeneration and 2) dominant drivers of seedling regeneration. Data were analysed using linear regression models, breakpoint analysis and mixed-effects modelling. Early forest development (<20 years) exhibited the most changes in canopy composition and structure, forest floor dynamics, seedling community and microclimate. This period saw significant increases in canopy stem abundance, height, basal area and leaf litter cover. Significant declines occurred for light transmittance, herbaceous cover and daily soil and air temperature range within the same timeframe. Dominant traits amongst the seedling community included early successional species, tree species, shade and drought tolerant species, insect-pollinated species and frugivory dispersed species. Seedlings with these traits had higher species richness levels across the whole chronosequence.

Collectively, five biotic drivers representing forest composition, structure and landscape factors strongly influenced seedling diversity. Seedling diversity increased with the proportion of surrounding natural landcover, sapling diversity, basal area, canopy diversity and herbaceous cover. The influence of these predictors of seedling diversity, was more significant when modelled as a set, than when viewed independently. Geographic location (city) was indicated as a stronger predictor for similarities in canopy and seedling community composition than the age of the restoration planting. This was shown by stronger clustering of sites according to their city, more so than forest planting age, in a non-metric multidimensional scaling analysis. 
Our results provide valuable insight to restoration practitioners on the outcomes of urban restoration programmes implemented across much of New Zealand and helps close the gap between the science of restoration ecology and the practice of ecological restoration. 


\section{ACKNOWLEDGMENTS}

Firstly, thank you to my supervisor Stephen Hartley for your guidance and support throughout my master's degree. Your supervision has been instrumental in helping me to achieve goals and maintain motivation and progression towards the finish line. I've sincerely appreciated your expertise in statistics, and the patience you showed when trying to teach me statistical concepts, methods and especially how to code in R. Thank you to Kiri Wallace for doing a fantastic job managing the continuous barrage of logistical matters that needed organising so I could run a successful and smooth-running field season with few issues or stressors. It was great having you join me in the field too and I'm most grateful for your advice during this time on how to improve processes and efficiencies. Your on-going support throughout my master's research has been invaluable. Thank you to my field technicians who assisted me during the long 4-month field season and enthusiastically working alongside me in all weather and site conditions: Maggie Shepperd, Chris Ralph and Florence Kelly. I would also like to thank those who shared their knowledge and donated their time to assist this project, from helping to identify unknown plant species, to assisting us in finding research study sites, to reviewing a large collection of plant trait data: Anita Benbrook, Owen Spearpoint, Colin Meurk, Leon Perrie, Patrick Enright, John Barkla, John van den Hoeven, Lloyd Esler, David Lyttle, Janice Lord, Brian and Chris Rance, Invercargill City Council, the Department of Conservation, Paul Pope, The Dunedin Amenities Society, Dunedin City Council, Waimakariri District Council, Antony Shadbolt, Christchurch City Council, Leigh Marshall, Nelson City Council, and Wellington City Council. A huge thank you as well to the landowners and community groups who graciously allowed me to conduct my research on properties they are stewards of. Lastly, a very special mention and whole-hearted thank you to Gerry Westhuis for allowing me to rent your wonderful motorhome for the South Island trip. It was an amazing experience and my journey would not have been as enjoyable if we had to find somewhere new to stay every week. We absolutely loved having a consistently familiar and homely place to return to at the end of each day. Thank you for always being available and super flexible when the odd mechanical hiccup occurred. Funding for this research was provided in part by the People, Cities \& Nature research programme, which is funded by a Ministry of Business, Innovation and Employment grant (MBIE UOWX1601) from the New Zealand government. Research Funds were also granted by the Wellington City Council, Wellington Botanical Society \& Victoria University of Wellington Centre for Biology and Restoration Ecology. 
$\begin{array}{ll}\text { ABSTRACT } & 3\end{array}$

$\begin{array}{ll}\text { ACKNOWLEDGMENTS } & 5\end{array}$

$\begin{array}{ll}\text { CONTENTS } & 6\end{array}$

$\begin{array}{ll}\text { LIST OF FIGURES } & 8\end{array}$

LIST OF TABLES 11

$\begin{array}{lll}\text { ACRONYMS } & 14\end{array}$

CHAPTER 1: GENERAL INTRODUCTION \& METHODS 15

$1.1 \quad$ Restoration of Urban Forests

1.2 Assessment and Monitoring of Restoration Success 16

$\begin{array}{lll}1.3 & \text { Factors Known to Inhibit Restoration Success } & 17\end{array}$

1.4 Research Outline and Aims $\quad 19$

$\begin{array}{lll}1.5 & \text { Methods } & 20\end{array}$

$\begin{array}{lll}\text { 1.5.1 Study Sites } 20 & 20\end{array}$

1.5.2 Permanent Vegetation Plot Set Up 23

1.5.3 Vegetation Data Collection 24

1.5.4 Environmental Data Collection 26

1.5.5 Landscape Features Data Collection 26

1.5.6 Species Traits Compilation 29

1.5.7 Summary of Ecosystem Variables Calculated for Analysis 30

1.5.8 Data Preparation and Analysis 30

CHAPTER 2: TEMPORAL DEVELOPMENT OF RESTORED URBAN FORESTS 32

$2.1 \quad$ Introduction $\quad 32$

2.2 Methods $\quad 35$

2.2.1 Data Analysis 
2.3 Results 36

2.3.1 Forest Canopy Development $\quad 39$

2.3.2 Changes in Forest Floor Dynamics and Microclimate 42

2.4 Discussion 44

2.4.1 Ecological Restoration of Urban Forests 44

CHAPTER 3: TRENDS AND DRIVERS OF NATIVE SEEDLING REGENERATION 50

$\begin{array}{lll}3.1 & \text { Introduction } & 50\end{array}$

$\begin{array}{lll}3.2 & \text { Methods } & 51\end{array}$

3.2.1 Data Analysis 52

3.3 Results 53

3.3.1 Temporal Trends of Native Seedling Regeneration 57

3.3.2 Dominant Drivers of Native Seedling Diversity 60

$\begin{array}{lll}3.4 & \text { Discussion } & 63\end{array}$

3.4.1 Patterns of Native Seedling Regeneration 63

3.4.2 Drivers of Native Seedling Regeneration 66

CHAPTER 4: SUMMARY \& RECOMMENDATIONS 70

$\begin{array}{lll}4.1 & \text { Summary } & 70\end{array}$

4.2 Recommendations for Restoration Practice 72

$\begin{array}{ll}\text { REFERENCES } & 74\end{array}$

APPENDIX 1: LANDCOVER \& LAND-USE INFORMATION 83

APPENDIX 2: SPECIES-SPECIFIC DATA 91

APPENDIX 3: SPECIES LIST AND TRAIT DATA 94

APPENDIX 4: CORRELATION COEFFICIENTS 99 


\section{LIST OF FIGURES}

Figure 1: Maps showing the location of a) New Zealand and the five cities sampled, and in decreasing latitude from north - south the cities of: b) Wellington, c) Nelson, d) Dunedin, e) Christchurch and f) Invercargill which had 9 sites selected within each, except for Dunedin which had eight. Software used for map creation: ArcMap. 21

Figure 2: Permanent plot layout used in study, with eight subplots each 5x5m. 23

Figure 3: Methodology for measuring the number and diameter of tree stems........ 24

Figure 4: Height tiers for classification of seedling heights. Plants recorded as $<15 \mathrm{~cm}$ were in tier 1

Figure 5: Example of a study site (Izard Park, Wellington) and its proportion of various landcover classes within a $1 \mathrm{~km}$ radius. Landcover classes and maps retrieved using LCDB v4.1.

Figure 6: A two-dimensional NMDS ordination of the differences in canopy species composition across five cities and a forest age chronosequence based on Bray-Curtis similarities (stress $=$ 0.23). City codes are: Wellington (Wgn), Nelson (Nel), Christchurch Cch), Dunedin (Dun) and Invercargill (Inv). 38

Figure 7: Linear regression models for forest development across a planting age chronosequence, focusing on woody species (trees and shrubs). Plots show changes in a) abundance, b) species richness, d) total basal area, e) average canopy height, and f) average light transmittance. Linear regression analysis without breakpoints was the preferred model for species diversity (c). The red points in figures a and b are the abundance and species richness of exotic species. However, a linear model was not fit to either of these variables due to a lack of data points. All variables except diversity and light transmittance were log transformed. All models were significant except diversity.

Figure 8: Linear regression models for changes in canopy species traits (successional stage and maximum height class) across a planted forest chronosequence. Plots show changes in species richness within a) successional class and b) structural class. All trait categories fitted linear models except for pioneer successional species and medium-sized tree species which had breakpoints. Purple points within the successional class plot represent late successional species which a linear model would not fit to due to a lack of data points. Only pioneer and medium sized tree species had significant models. 
Figure 9: Linear regression models for changes in forest floor dynamics and microclimate across a planted forest chronosequence. Changes in the forest floor dynamics and microclimate over time. Plots show changes in total cover of a) leaf litter and b) herbaceous plants, and daily average range in c) soil temperature at $10 \mathrm{~cm}$ depth, and d) air temperature at $1 \mathrm{~m}$ above ground level. Leaf litter and herbaceous cover were log transformed. All models were significant except air temperature.

Figure 10: Presence of native seedling species across study sites and the average abundance (average number of individuals) of each species when present in a plot. Species chosen to display in graph which were either a) the most wide-spread with a minimum presence across 5 sites or b) the highest average abundance with a minimum abundance of 20. Average abundance was calculated by dividing the number of sites a species was present in, by the total count recorded. A key to species codes can be found in Appendix 2.

Figure 11: A two-dimensional NMDS ordination of the similarities in seedling community composition across five cities and a forest age chronosequence based on Bray-Curtis similarities (stress = 0.25). City codes are: Wellington (Wgn), Nelson (Nel), Christchurch Cch), Dunedin (Dun) and Invercargill (Inv). 56

Figure 12: Linear regression models for seedling regeneration dynamics across a forest planting chronosequence. Plots show changes in seedling a) abundance, b) species richness, c) diversity, d) structural classes, e) successional classes, f) drought tolerance, g) shade tolerance, h) pollinator traits, i) dispersal traits and j) reproductive traits. Yellow points within the pollinator trait plot represent bird pollinated species and low data points meant a linear model would not fit to the data. Purple points within the successional class plot represent late successional species which a linear model would not fit to due to a lack of data points. All variables were log transformed except for seedling diversity. Only significant models were overall species richness and the species richness of tree species. 58

Figure 13: Mixed-effects models to predict potential drivers of seeding regeneration. Model 1 (a) includes all abiotic variables and Model 2 (b) includes all biotic variables thought to play a role in seedling regeneration. Model 3 (c) includes only the significant variables found Models $1 \& 2$. The inner confidence interval of 1 standard deviation is represented by the thick line and the outer confidence interval of 2 standard deviations is represented by the thin line. 61

Figure 14: Linear regression models of dominant drivers indicated in the linear mixed-effects model. Variables were more significant as a group in the linear mixed-effect models than when assessed independently. Independent significant drivers of seedling regeneration were a) 
canopy diversity and b) sapling diversity. Non-significant independent drivers were c) proportion of surrounding natural landcover d) basal area and 3) herbaceous cover.

63

Figure 15: Regional landcover polygons. Created using LCDB v4.1 and produced on ARCmap. Locations are a) Wellington, b) Nelson, c) Christchurch, d) Dunedin and e) Invercargill. Each circle has a radius of $1 \mathrm{~km}$. 90 


\section{LIST OF TABLES}

Table 1: The SER International Primer on Ecological Restoration key attributes of a fully recovered ecosystem. Attributes measured within this study are indicated in the far right column. (Society for Ecological Restoration International Science \& Policy Working Group, 2004)

Table 2: Annual city climate data. Data are the mean annual values for the 1971-2000 period. Climate data National Institute of Water and Atmospheric Research (2019). 22

Table 3: Urban forest restoration site information. City, site location, prior land-use, latitude, planting age and the proportion of surrounding natural landcover $<1 \mathrm{~km}$ radius of each site.28

Table 4: Trait types and categories compiled for species recorded within study 29

Table 5: Ecosystem variables calculated within five conceptual frameworks. These frameworks include canopy \& seedling tiers, site-level attributes, landscape-level factors and species-level plant traits. 30

Table 6: The top $10 \%$ of woody species found at the highest number of study sites. Species are ranked in order of the most widely distributed across sites. Number of stems is the total count for each species across all 44 study sites. Associated traits for these species are provided...... 37 Table 7: Summary of canopy plant data for each city. The total count of all woody plants is provided, with separate totals for trees $\left(1^{\text {st }}\right.$ number $)$ and shrubs ( $2^{\text {nd }}$ number $)$ in brackets. Trees and shrubs are life form classifications for each species (sourced from NZPCN, Appendix 3). Basal area $\left(\mathrm{m}^{2}\right.$ per hectare) is averaged across all plots within each city. 38

Table 8: Regression analysis of the effect of forest age on canopy abundance, species richness, diversity, basal area, light transmittance and height. Models with the lower AIC are displayed in the results section above. Canopy abundance, species richness and diversity measured per plot $\left(200 \mathrm{~m}^{2}\right)$. The p-value and beta estimates for the breakpoint analysis represents the significance of the first slope in the model. The second slope in all breakpoint models were not significant. In all cases $\mathrm{n}=44$. Significance codes: $* \mathrm{p}<0.05, * *=\mathrm{p}<0.01$, $* * *=\mathrm{p}<0.001$, ***** $=\mathrm{p}<0.0001$ 40

Table 9: Regression analysis of the effect of forest age on species richness of canopy species traits from different structural and successional guilds. Models with the lower AIC are displayed in the results section above. Species richness measured per plot $\left(200 \mathrm{~m}^{2}\right)$. The p-value 
and beta estimates for the breakpoint analysis represents the significance of the first slope in the model. The second slope in all breakpoint models were not significant. In all cases $n=44$.

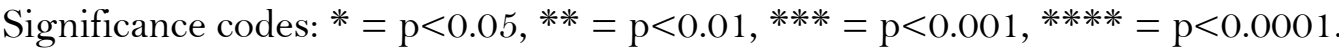

Table 10: Regression analysis of the effect of forest age on forest floor dynamics and microclimate. Models with the lower AIC are displayed in the results section above. The pvalue and beta estimates for the breakpoint analysis represents the significance of the first slope in the model. The second slope in all breakpoint models were not significant. In all cases $n=44$. Significance codes: $*=\mathrm{p}<0.05,{ }^{*} * \mathrm{p}<0.01,{ }^{*} * *=\mathrm{p}<0.001$, $* * * * * \mathrm{p}<0.0001$.

Table 11: Summary of seedling regeneration by city. Displayed is the total richness (Rich.) and count (Cnt.) of seedling groups recorded from each of the 9 sites across each city (except Dunedin which had 8 sites).

Table 12: Regression analysis of the effect of forest age on seedling regeneration dynamics. The seedling trait response variable is the species richness per site (species $\left./ 70 \mathrm{~m}^{2}\right)$. Models with the lower AIC are displayed in the results section above. The p-value and beta estimates for the breakpoint analysis represents the significance of the first slope in the model. The second slope in all breakpoint models were not significant. In all cases $n=44$. Significance codes: $*$ $\mathrm{p}<0.05, * *=\mathrm{p}<0.01, * * * * \mathrm{p}<0.001, * * * *=\mathrm{p}<0.0001$

Table 13: Two way ANOVA of predictor variables for the three models. Model 1 includes all abiotic and Model 2 includes all biotic variables thought to play a role in seedling regeneration. Model 3 includes only the significant variables from Model 1 \& 2 . Beta estimates are also included. Significance values were calculated using ANOVA. Significance codes: $*=p<0.05$, ** $=\mathrm{p}<0.01, * * *=\mathrm{p}<0.001, * * * *=\mathrm{p}<0.0001$.

Table 14: Broad landcover categories and the specific landcover classes included. Retrieved from LCDB 4.1 (Landcare Research, 2019)....

Table 15: Detailed descriptions of the specific landcover classes that sit within the broad landcover categories: Retrieved from LCDB 4.1 (Landcare Research, 2019)......

Table 16: Historical land-use categories and descriptions.

Table 17: Presence and dominance of native species across all 44 study sites. Species listed in the order of most sites it was recorded within.

Table 18: Compiled plant species list and associated traits used in the analysis for this study. 
Table 20: Table of coefficients. The R-core base package (R Project, 2019) was used to compute correlations and between variables and associated p-values using Pearson correlation coefficient. Correlation figures are in the top half of the matrix and p-values on the bottom half. Moderate (0.5) and high (0.9) correlations are highlighted. Only continuous variables were included in the correlation analysis. 99 
NVS

National Vegetation Survey

SER

Society for Ecological Restoration

DBH

Diameter at Breast Height

ha

Hectare

Ind.

Individuals

Yrs.

Years

Adj. R ${ }^{2}$

Adjusted R-squared

AIC

Akaike Information Criterion

$\triangle \mathrm{AIC}$

Delta AIC

№

Number

NZPCN

New Zealand Plant Conservation Network

NIWA

National Institute of Water and Atmospheric Research

LMM

Linear Mixed-Effects Model 


\subsection{Restoration of Urban Forests}

The restoration of indigenous forests in urban areas has become a policy imperative for many cities throughout New Zealand (Environment Canterbury, 2012; Wellington Regional Council, 2013; Forestry New Zealand, 2018). With a 70\% reduction in indigenous forest and shrubland cover since the pre-human state (Allen et al., 2013b) and a growing urban population, impetus for change and investment into green infrastructure is being ramped up by a suite of traditional and non-traditional investors including regional \& local councils, government, scientists, restoration practitioners, planners, community volunteers, companies and institutions (Auckland Regional Council, 2018; Brown, 2015; Forestry New Zealand, 2018; Norton et al., 2018). The historical and contemporary degradation of forest ecosystems is a concern, not only because of the intrinsic value of intact indigenous ecosystems, but livelihoods are heavily dependent on the ecological, social and economic benefits of urban nature (Mansourian et al., 2005). In recognition of the value of restoring natural biodiversity, ecosystem services, sustainability and resilience back into urban landscapes (Sullivan et al, 2009); tree plantings of various scales have been taking place across New Zealand over several decades. The ultimate aim of the ideal urban restoration programme, which is the basis upon which this thesis sits, is to create conditions which enable planted urban forests to become stable, vigorous and selfsustaining (Porteous, 1993).

The restoration of self-sustaining and ecologically functioning urban plant communities is a proficiency that has been refined through a few decades of lessons learned (Mansourian \& Vallauri, 2014; Ozarski, 2015; Rastandeh, 2018). There is a movement underway from simple revegetation to full ecosystem reconstruction, which involves focusing beyond bringing back just native trees and birds, but also includes the full suite of ecosystems, habitats, species assemblages, complex interactions and processes (Aerts \& Honnay, 2011; Bradshaw, 1983; Saunders \& Hobbs, 1995). Restoration practitioners nowadays also realise the importance of historical and ecological knowledge of the local landscape to establish the most suitable composition of plant species and have improved planting practices. Today's practitioners are increasingly implementing restoration programmes based on ecological research, e.g. ecosourced seeds to improve planting survival and genetic diversity (Breed et al., 2013; Thomas et al., 2014), species with traits that can thrive within the environmental conditions and anthropogenic disturbances operating at the site (Guariguata \& Ostertag, 2001; Ostertag et al., 
2015; Tilman \& Lehman, 2001), and appropriate species to mimic the stages of forest succession (Walker et al., 2003).

Restoration programmes are now a vital tool used to initiate, re-create or accelerate ecological succession of forest species; and improve ecosystem services and function (Prach \& Walker, 2011; Zeunert, 2013) in degraded urban landscapes. Ecological succession is a temporal shift in species dominance (Smith \& Huston, 1989) primarily driven by abiotic factors such as availability of light, water, nutrients and suitable microclimate conditions (Chai et al., 2016; Gaviria \& Engelbrecht, 2015; Li et al., 2005) and secondary biotic factors such as regional species pool, soil seed bank, propagule sources (Overdyck \& Clarkson, 2012) and species interactions (Borgmann \& Rodewald, 2005; Guariguata \& Ostertag, 2001).

Creating a trajectory towards forest ecological succession relies on four basic prerequisites. These are: 1) the presence of favourable biotic and abiotic conditions for plant establishment and growth, 2) the existence of a soil seedbank containing native plant species, 3) the natural arrival of new propagules with time and 4) differing and complementary ecological behaviours between species in the community (Pickett \& Cadenasso, 1995). The absence of one of these prerequisites in restored urban forests creates a barrier to successful natural succession (Rodrigues et al., 2011) and the subsequent success of the restoration programme. To overcome these barriers, practitioners must regularly monitor the state of the restoration site, followed by adjustment of restoration strategies to enable the complete restoration of a self-sustaining and ecologically functioning urban forest.

\subsection{Assessment and Monitoring of Restoration Success}

Monitoring and assessment of a restoration site's ecological state after initial planting activities is the most important step for successful restoration (Mansourian et al., 2005), enabling improved understanding of the dynamics and barriers which are influencing site successional trajectory. In order to assess whether a restoration programme is successful and report on the current status and trends occurring within areas undergoing restoration, practitioners need to collect data, preferably long-term and make sense of this data. This is a requirement for 1) assessing the effectiveness of management actions (Allen et al., 2003), 2) ensuring the ecological trajectory of the site is on the right track (Takahashi et al., 2003), and 3) improving our knowledge on the complexities of forest ecosystem dynamics (Allen et al., 2013b). Unfortunately, assessment and especially long-term monitoring of urban forest restoration programmes is rarely pursued. This is usually due to limited resources such as time and funding, a perception of low value by pratitioners, or a lack of requirement by funding agencies. 
Because of this, there is still uncertainty as to how effective urban restoration programmes actually are over the timescales forests exist on, e.g. hundreds or thousands of years (Wortley et al., 2013).

Post-planting assessments are particularly important for restoration areas located within urban regions (McPherson, 1993; Morgenroth \& Östberg, 2017). Restoring urban forests presents many challenges due to the countless variables that can hinder the process (Miyawaki, 2008) and practitioners need to better understand these barriers to restoration efforts at both the local scale and surrounding wider landscape. Measures of plant community and plantenvironment interactions can provide an indication to practitioners of the complex dynamics taking place (Rodríguez-García et al., 2011; Soliveres \& Maestre, 2014). These dynamics may include changes in density, diversity and species composition (Gómez-Aparicio, 2009); the inherent traits of regenerating species such as tolerances, vulnerabilities and dispersal mechanisms, and ecological processes occurring at the landscape and site scales (Archer \& Pyke, 1992). These community dynamics lead to rolling changes in dominant species compositions and interactions over time (Donoso et al., 2017) which need to be understood to better enable appropriate adaptive management strategies. The fundamental characteristics measured internationally and domestically to assess forest ecosystems include composition, structure and function (Allen, 1993; Ruiz-Jaen \& Mitchell Aide, 2005). The richness and diversity of species is expressed in the assessment of composition, the structure provides information on the physical organisation of a forest and the function alerts us to the state of the evolutionary and ecological processes occurring within the forest ecosystem (Monks et al., 2013).

\subsection{Factors Known to Inhibit Restoration Success}

The Society for Ecological Restoration (SER) states that a fully recovered forest ecosystem is one which has nine attributes which relate to form, function and stability (Clewell \& Aronson, 2013) (Table 1). These include similarity to reference conditions, presence of indigenous species, presence of functional groups, capacity to sustain populations, normal functioning, landscape integration, elimination of threats and resilience. 
Table 1: The SER International Primer on Ecological Restoration key attributes of a fully recovered ecosystem. Attributes measured within this study are indicated in the far right column. (Society for Ecological Restoration International Science \& Policy Working Group, 2004)

\begin{tabular}{|c|c|c|c|c|}
\hline Category & Abr. Attribute & $\begin{array}{l}\text { Full Attributes of Restored } \\
\text { Ecosystem }\end{array}$ & Example & $\begin{array}{l}\text { Measured in } \\
\text { This Study }\end{array}$ \\
\hline Form & $\begin{array}{l}\text { Similarity to } \\
\text { reference } \\
\text { conditions }\end{array}$ & $\begin{array}{l}\text { Contains a characteristic } \\
\text { assemblage of species that occur in } \\
\text { reference ecosystem and provides } \\
\text { appropriate community structure. }\end{array}$ & $\begin{array}{l}\text { Reinstatement of layers, } \\
\text { faunal food webs, and } \\
\text { spatial habitat diversity. }\end{array}$ & NA. \\
\hline Form & $\begin{array}{l}\text { Presence of } \\
\text { indigenous } \\
\text { species }\end{array}$ & $\begin{array}{l}\text { Consists of indigenous species to } \\
\text { the greatest practicable extent. }\end{array}$ & $\begin{array}{l}\text { Presence of desirable plant } \\
\text { and animal species and } \\
\text { absence of undesirable } \\
\text { species. }\end{array}$ & $\begin{array}{l}\text { Native and } \\
\text { exotic species } \\
\text { richness, } \\
\text { abundance, } \\
\text { diversity }\end{array}$ \\
\hline Function & $\begin{array}{l}\text { Presence of } \\
\text { functional } \\
\text { groups for } \\
\text { development } \\
\text { and stability }\end{array}$ & $\begin{array}{l}\text { All functional groups necessary for } \\
\text { continued development and } \\
\text { stability are represented or, the } \\
\text { missing groups have the potential } \\
\text { to colonize naturally. }\end{array}$ & $\begin{array}{l}\text { Presence of plant groups \& } \\
\text { species with different } \\
\text { phylogenetics (grass, sedge, } \\
\text { ferns) or life-form } \\
\text { characteristics (shade } \\
\text { tolerance). }\end{array}$ & $\begin{array}{l}\text { Species traits: } \\
\text { form, } \\
\text { tolerances, } \\
\text { dispersal, } \\
\text { reproduction, } \\
\text { diversity. }\end{array}$ \\
\hline Function & $\begin{array}{l}\text { Capacity of } \\
\text { physical } \\
\text { environment to } \\
\text { sustain } \\
\text { populations }\end{array}$ & $\begin{array}{l}\text { Physical environment capable of } \\
\text { sustaining reproducing } \\
\text { populations of species necessary } \\
\text { for continued stability or } \\
\text { development along desired } \\
\text { trajectory. }\end{array}$ & $\begin{array}{l}\text { Reinstatement of } \\
\text { hydrological, climate, } \\
\text { substrate conditions. }\end{array}$ & $\begin{array}{l}\text { Air and soil } \\
\text { temperature, } \\
\text { light } \\
\text { availability }\end{array}$ \\
\hline Function & $\begin{array}{l}\text { Normal } \\
\text { functioning }\end{array}$ & $\begin{array}{l}\text { Apparently functions normal for } \\
\text { its ecological stage of } \\
\text { development, and signs of } \\
\text { dysfunction are absent. }\end{array}$ & $\begin{array}{l}\text { Reinstatement of nutrient } \\
\text { cycling, habitat elements, } \\
\text { plant-animal interactions, } \\
\text { normal stressors, } \\
\text { reproduction and species } \\
\text { regeneration. }\end{array}$ & $\begin{array}{l}\text { Native seedling } \\
\text { regeneration }\end{array}$ \\
\hline Function & $\begin{array}{l}\text { Landscape } \\
\text { integration }\end{array}$ & $\begin{array}{l}\text { Suitably integrated into larger } \\
\text { ecological landscape, with which it } \\
\text { interacts through abiotic and } \\
\text { biotic flows and exchanges. }\end{array}$ & $\begin{array}{l}\text { Reinstatement of linkages, } \\
\text { connectivity and flows for: } \\
\text { migration, genes, } \\
\text { hydrology, fire. }\end{array}$ & $\begin{array}{l}\text { Proportion of } \\
\text { surrounding } \\
\text { natural } \\
\text { landcover }\end{array}$ \\
\hline Stability & $\begin{array}{l}\text { Elimination of } \\
\text { threats }\end{array}$ & $\begin{array}{l}\text { Threats to health and integrity } \\
\text { from surrounding landscape have } \\
\text { been eliminated or reduced as } \\
\text { much as possible. }\end{array}$ & $\begin{array}{l}\text { Elimination or control of } \\
\text { threats such as } \\
\text { overutilization, } \\
\text { contamination, invasive } \\
\text { species. }\end{array}$ & $\begin{array}{l}\text { Exotic species } \\
\text { abundance \& } \\
\text { richness. }\end{array}$ \\
\hline Stability & Resilience & $\begin{array}{l}\text { Sufficiently resilient to endure } \\
\text { normal periodic stress events in } \\
\text { the local environment that serve to } \\
\text { maintain the integrity of the } \\
\text { ecosystem }\end{array}$ & $\begin{array}{l}\text { Creation of structural } \\
\text { layers, functional diversity, } \\
\text { spatial habitat diversity. }\end{array}$ & $\begin{array}{l}\text { Canopy } \\
\text { diversity, } \\
\text { functional } \\
\text { traits, tree } \\
\text { height classes. }\end{array}$ \\
\hline Stability & $\begin{array}{l}\text { Self- } \\
\text { sustainability }\end{array}$ & $\begin{array}{l}\text { To the same degree as its } \\
\text { reference ecosystem, potential to } \\
\text { persist indefinitely under existing } \\
\text { environmental conditions. Aspects } \\
\text { of biodiversity, structure, and } \\
\text { function may fluctuate as part of } \\
\text { normal ecosystem development, } \\
\text { periodic stress, disturbance events } \\
\text { and as environmental conditions } \\
\text { change. }\end{array}$ & $\begin{array}{l}\text { Natural regeneration of } \\
\text { native trees, shrubs, ferns, } \\
\text { lianes and other plant } \\
\text { forms. }\end{array}$ & $\begin{array}{l}\text { Native seedling } \\
\text { regeneration. }\end{array}$ \\
\hline
\end{tabular}


The regeneration of a diverse array of native trees, shrubs, ferns and herbaceous seedlings beneath planted canopies, is a key process in forest succession (Arroyo-Rodriguez et al., 2017) and a fundamental attribute of fully-recovered self-regenerating forests (Proença et al., 2012). However, this dynamic is generally lacking and what drives it is unknown. Some factors that are known to inhibit the germination and survival of native seedlings within planted forests include the age of the restored forest plantings (Laughlin \& Clarkson, 2018), appropriate initial planting mix of pioneer and early successional species (de Souza \& Batista, 2004), competition with herbaceous weeds (Wallace et al., 2017), microclimate of the understory (Badano et al., 2015), inherent plant traits such as shade and drought tolerance (Comita \& Hubbell, 2009), seed source availability (Carter \& Blair, 2013), and canopy composition and openness (Beckage et al., 2005). However, it is unclear whether some are more dominant drivers of regeneration than others.

Furthermore, there are a number of temporal dimensions to restoration that are not well addressed. For example, do we know how long it might take to achieve success? Would the same outcome be achieved by a "hands-off" approach? Does restoration practice simply speedup natural successional processes or redirect succession? How do we know when to intervene, if at all? Many studies look at a singular cause and effect relationship within plant communities (Bose et al., 2016; Larson et al., 2016), yet ecological interactions are often complex, interrelated and occur over long biological time-scales, making any conclusions on causal relationships difficult. The research presented here takes a 'big-picture' approach, by assessing temporal patterns in restored forest development and seedling regeneration and the dominant drivers of natural seedling regeneration.

\subsection{Research Outline and Aims}

This research investigates 1) the temporal patterns of restored forest development and seedling regeneration 2) the dominant drivers of seedling regeneration. Forest structure, composition, plant species traits, landscape and microclimate variables were measured from 44 permanent urban forest restoration plots installed across five cities within New Zealand. In each city (Wellington, Nelson, Christchurch, Dunedin and Invercargill), plots were established following the National Vegetation Survey (NVS) permanent plot protocols, in restored urban forests occurring along a planting age chronosequence ( 5 - 59 years since the initial tree plantings were established). This data collection design allowed for the determination of forest development and regeneration patterns over the dynamic first decades of forest development 
and specifically, the identification of key drivers of seedling regeneration, which are vital for assessing the success of restoration.

Following this first introductory chapter there are two data chapters (chapter 2 and chapter 3 ). Chapter 2 investigates temporal trends of early forest development using linear regression and breakpoint analysis. This enables some predictive power about when conditions are optimal for specific restoration activities (e.g. enrichment planting of late successional species) and what changes to planting strategies might be needed to enhance ecosystem successional trajectory (e.g. tree abundance, species richness, functional richness and structural complexity). Chapter 3 looks at changes in seedling regeneration over time and shows how canopy, climate, site and landscape factors can all influence seedling regeneration. This provides an overview of the dominant drivers of seedling regeneration which restoration practitioners must consider when managing successful restoration programmes.

The practical implications for restoration practice include an increased ability to predict the impact of planting strategies, site conditions and landscape context on a restored forests' ecological development and dynamics of native seedling recruitment. The thesis concludes with management recommendations and restoration guidelines for urban forest restoration in New Zealand cities.

\subsection{Methods}

\subsubsection{Study Sites}

The study sites are spread throughout the north and south islands of New Zealand (Figure 1), located within five cities, four of which are ranked within the 10 largest cities in the country. There is a 5 degree latitudinal difference between the northern-most city of Wellington which also has the highest urban population of 215,400 , and the southernmost city of Invercargill which sits below Nelson, Christchurch and Dunedin and has the smallest population size of 51,200 .

Forty-four urban restoration sites along a forest restoration chronosequence between 5-59 years since planting where chosen for this study. The chronosequence approach is expedient, allowing data collection to be done at a single point in time, that would otherwise take decades or longer to observe longitudinally (Capers et al., 2005), with space-for-time substitution. Nine sites were selected within each city (Table 3) except Dunedin which had eight sites. 

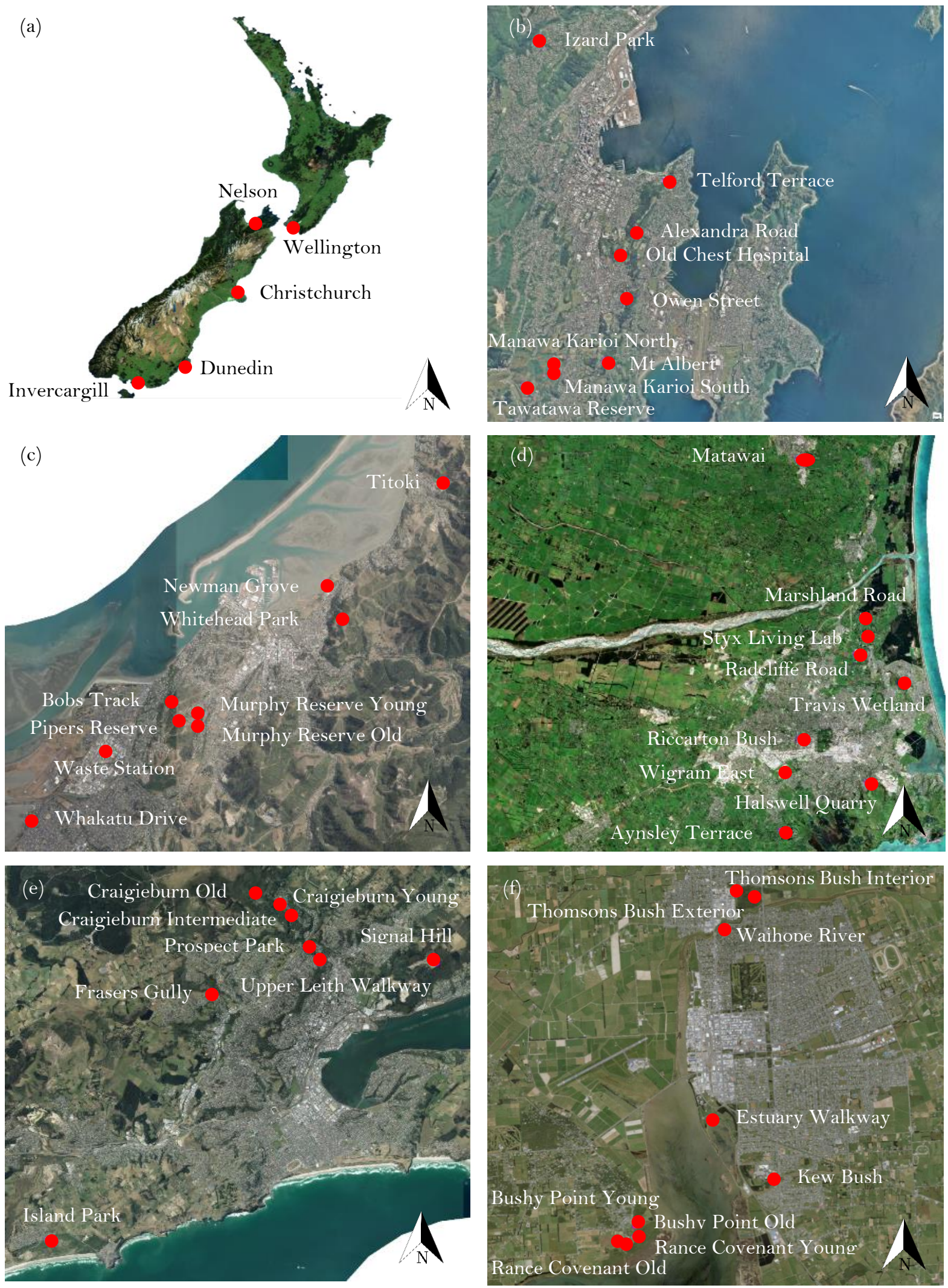

Figure 1: Maps showing the location of a) New Zealand and the five cities sampled, and in decreasing latitude from north - south the cities of: b) Wellington, c) Nelson, d) Dunedin, e) Christchurch and f) Invercargill which had 9 sites selected within each, except for Dunedin which had eight. Software used for map creation: ArcMap. 
Site specific restoration goals, strategies or practices were not considered during the selection process or recorded for integration into analysis. Restoration management practices are undertaken by various practitioners, but predominantly by regional and city councils and local community groups and management records are poor, if any exist, for most sites. However, follow up care generally ranged from no input to a management regime involving the regular removal of weedy exotic plants, extensive enrichment plantings and introduced animal control. Regardless of site management practice, it is possible to examine a developing forest at a static point and learn from relationships between key variables (e.g. degree of canopy closure seedling densities). Site selection criteria included 1) the site had to have been cleared of all vegetation and replanted with native species and 2 ) the site needed to be at least $20 \mathrm{~m}^{2}$.

Climate data for each of the cities within the study (Table 2 ) was retrieved from the National Institute of Water and Atmospheric Research (NIWA). Wellington had the highest annual mean rainfall of $1249 \mathrm{~mm}$, air temperature $\left(12.8^{\circ} \mathrm{C}\right)$ and $10 \mathrm{~cm}$ soil temperature $\left(12.24^{\circ} \mathrm{C}\right)$; with the lowest annual mean ground frost days (10 days). Christchurch had the lowest average rainfall of $648 \mathrm{~mm}$ and the highest relative humidity of $85.07 \%$. Invercargill had both the lowest mean annual air and $10 \mathrm{~cm}$ soil temperature of $9.9^{\circ} \mathrm{C}$ and $9.23^{\circ} \mathrm{C}$ respectively with the highest mean ground frost days (94 days). Nelson city had the highest annual mean sunshine hours at 2405 hours and lowest mean wind speed of 12 kilometres per hour.

Table 2: Annual city climate data. Data are the mean annual values for the 1971-2000 period. Climate data National Institute of Water and Atmospheric Research (2019).

\begin{tabular}{|c|c|c|c|c|c|c|c|c|}
\hline $\begin{array}{l}\text { City \& Climate } \\
\text { Station Location }\end{array}$ & $\begin{array}{r}\text { Rainfall } \\
(\mathrm{mm})\end{array}$ & $\begin{array}{r}\text { Sunshine } \\
\text { (hours) }\end{array}$ & $\begin{array}{r}\text { Temp } \\
\left(\text { mean }^{\circ} \mathbf{C}\right)\end{array}$ & $\begin{array}{r}\text { Temp } \\
\left(\max .{ }^{\circ} \mathbf{C}\right)\end{array}$ & $\begin{array}{r}\text { Temp } \\
\left(\min .{ }^{\circ} \mathbf{C}\right)\end{array}$ & $\begin{array}{r}\text { Ground } \\
\text { frost } \\
\text { (days) }\end{array}$ & $\begin{array}{r}\text { Relative } \\
\text { humidity } \\
(\%)\end{array}$ & $\begin{array}{r}10 \mathrm{~cm} \text { Soil } \\
\text { temp } \\
\left({ }^{\circ} \mathrm{C}\right)\end{array}$ \\
\hline $\begin{array}{l}\text { Wellington, } \\
\text { Kelburn }\end{array}$ & 1249 & 2065 & 12.8 & 31.1 & 1.9 & 10 & 82.89 & 12.24 \\
\hline $\begin{array}{l}\text { Nelson, } \\
\text { Nelson Airport }\end{array}$ & 970 & 2405 & 12.6 & 36.3 & 6.6 & 88 & 81.16 & 11.87 \\
\hline $\begin{array}{l}\text { Dunedin, } \\
\text { Musselburgh }\end{array}$ & 812 & 1585 & 11 & 35.7 & 8 & 58 & 75.85 & 10.00 \\
\hline $\begin{array}{l}\text { Christchurch, } \\
\text { Christchurch } \\
\text { Gardens }\end{array}$ & 648 & 2100 & 12.1 & 41.6 & 7.1 & 70 & 85.07 & 10.64 \\
\hline $\begin{array}{l}\text { Invercargill, } \\
\text { Invercargill } \\
\text { Airport }\end{array}$ & 1112 & 1614 & 9.9 & 32.2 & 9 & 94 & 83.35 & 9.23 \\
\hline
\end{tabular}




\subsubsection{Permanent Vegetation Plot Set Up}

Permanent plots are the standard and most widely applied of all methodologies for forest monitoring and research used in New Zealand and overseas. Permanent plot studies can detect long-term change in forest ecosystems, such as structure and composition (Bakker et al., 1996). When combined with the marking of individual trees, population parameters such as recruitment, growth and mortality rates can be calculated through time. Even though the data collected in this study was undertaken within one single survey, instead of over a long period of time, permanent plots were installed to enable the opportunity for these sites to be further studied in the future.

Following the method of Hurst and Allen (2007), one permanent plot was installed at each site. Plots were $200 \mathrm{~m}^{2}$ (10m x 20m) and divided into 8 smaller subplots of $5 \times 5$ metres to increase efficiency of data surveys and reduce the potential for over or under count errors when surveying individual plants (Figure 2). To enable easier re-location of the exact plot layout plots were permanently marked with steel underground bars $(25 \mathrm{~cm}$ long) at each corner, and above ground, visible $\mathrm{u}$-shaped-staples at the corners and at the cross section of the tapes and the plot centre $(n=16)$. Circular seedling plots of 1.5 metre radius were marked out at 10 locations along the internal tapes at 2.5 metres from the plot edge or sub-plot cross section. Air data loggers were installed at the centre of each plot. Soil data loggers were installed at the centre and one corner of each plot.

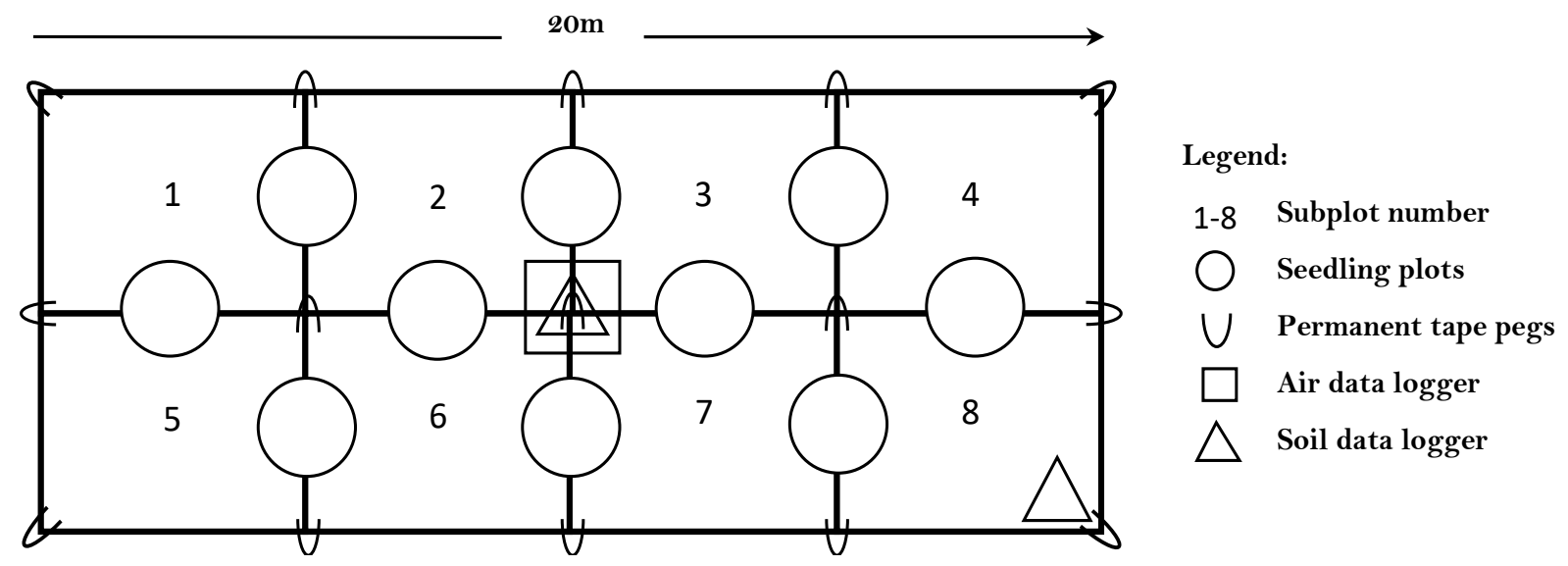

Figure 2: Permanent plot layout used in study, with eight subplots each $5 x 5 m$.

The methods and standards of the permanent plot are considered to have the following characteristics: 1) repeatable and reliable, 2) minimal pseudo-replication, 3) relocatable sample points, 4) easy to measure and re-measure, 4) does not require frequent measures, 5) comparable to data collected by other agencies (Bellingham et al., 2000). 
Permanent plots were established within urban forest restoration sites at locations which were, as much as feasible 1) away from planting boundaries, 2) away from public walking tracks, 3) away from streams and tributaries, and 4) randomly placed within the restored forest patch of a known age, if the scale of the planting site allowed (as many plots only just fit within the defined restored forest patch boundaries).

\subsubsection{Vegetation Data Collection}

Trees were defined as all woody plants and tree ferns that had stems $>2.5 \mathrm{~cm}$ diameter at breast height (DBH) (Hurst and Allen, 2007). All trees were recorded to species level within the entire 10x20m plot and tagged with a numbered metal tag for future identification. All stems $(>2.5$ $\mathrm{cm} \mathrm{DBH}$ ) of each tree were measured at $1.35 \mathrm{~m}$ height from the ground (Figure 3) to calculate basal area. These were always measured from the uphill side of the plant. Tree stems were not measured if they split from a branch above the $1.35 \mathrm{~m}$ mark (Figure 3 ).

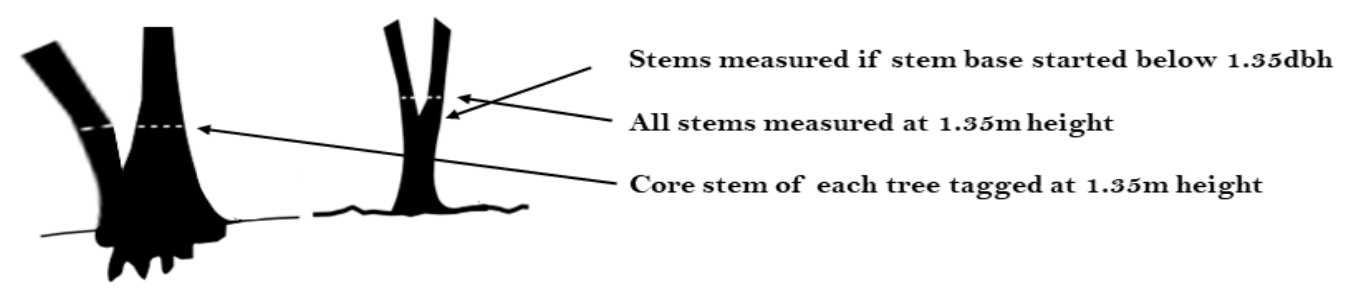

Figure 3: Methodology for measuring the number and diameter of tree stems.

Saplings were defined as woody plants $>1.35 \mathrm{~m}$ high and $<2.5 \mathrm{~cm} \mathrm{DBH}$ (Hurst and Allen, 2007). All saplings were recorded to species level and tallied within all eight subplots (the entire $10 \mathrm{x}$ $20 \mathrm{~m}$ plot, same sampling area as for trees). Saplings were recorded if their height was $>1.35 \mathrm{~m}$ above ground in their natural position (unmanipulated by researcher), from the uphill side of the plant. Trees and saplings with multiple stems growing from a visible singular root base were classified as one stem. Trees and saplings that may have had multiple joined stems but were not visible above ground were counted as separate individuals.

Seedlings were classified as all individual woody (trees, shrubs, vines) and non-woody (tree ferns, ground ferns) plants that were $<1.35 \mathrm{~m}$ high in their natural position (Hurst and Allen, 2007). Seedlings were identified to species level and counted within 10 circular seedling plots and assigned into one of 5 allocated height tiers of $<15 \mathrm{~cm}, 16-45 \mathrm{~cm}, 46-75 \mathrm{~cm}, 76-105 \mathrm{~cm}$, and $106-135 \mathrm{~cm}$ (Figure 4). 


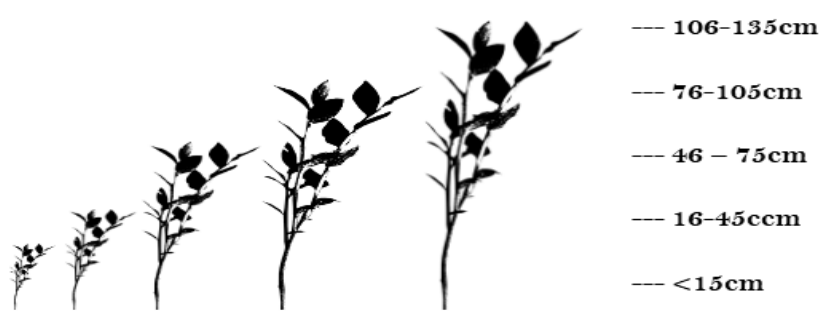

Figure 4: Height tiers for classification of seedling heights. Plants recorded as $<15 \mathrm{~cm}$ were in tier 1.

Each subplot was assessed for the estimated total percentage cover of the ground cover categories: herbaceous plants, leaf litter, mulch and bare ground. These percentages were then averaged into the total proportion of cover across the entire plot. Herbaceous plant cover included predominantly exotic, non-woody species which tend to dominate in the younger planting sites. Herbaceous groundcover also included some native fern species from genera such as Asplenium, Blechnum, Polystichum, Pteridium, Pyrrosia, Histiopteris and Hypolepis, and very occasionally native herbaceous species (e.g. Carex spp.).

One plant genus that researchers were not always able to identify to species level was Coprosma, due to the seedlings often being too small to be able to identify accurately using key features which are usually expressed in older individuals. If key features were absent leading to an inability to identify, these unknown individuals were recorded as Coprosma spp. All individuals of trees, saplings and seedling were identified to species level whenever possible, however if individuals were not identifiable during the field surveys, they were recorded as 'unknown' along with a description of the plant. Photos of the unknown taxa were added to a project folder on iNaturalist.NZ. Photos were reviewed later and identified with the help of field guides, plant keys and suggestions from botanists and plant enthusiasts on iNaturalist. Any individuals that were unable to be identified to species level were removed from analysis (except for individuals identified within the Coprosma genus, which were included in the analysis of site seedling densities only). Twenty-eight seedlings ( $<1 \%$ of total seedling observations) were unidentified within this study.

Light transmittance readings were recorded at each corner of the plot and at the centre. This was done using a handheld convex Spherical Crown Densiometer. Readings were conducted twice over 2 visits in the exact same location and facing the exact same direction. Canopy height was recorded by estimating the average canopy height across the entire plot. The estimated percentage cover of leaf litter and herbaceous plants was recorded within each subplot. 


\subsubsection{Environmental Data Collection}

Air temperature was recorded using HOBO MX2301A Data Loggers. The HOBO loggers are weatherproof, can be set up using wireless technology and have a range of $-40^{\circ} \mathrm{C}-70^{\circ} \mathrm{C}$. Within each plot the loggers were always attached to a tree nearest to the plot centre and at a height of $1 \mathrm{~m}$ above ground level. Soil temperature readings were recorded using DS190 iButton sensors. The iButton sensor is capable of reading $-55^{\circ} \mathrm{C}$ to $+100^{\circ} \mathrm{C}$ in $0.5^{\circ}$ increments. Two iButtons were installed in each plot, one buried at the centre and one at corner. The iButtons were placed at these same locations across all sites, buried to $10 \mathrm{~cm}$. Two iButtons were used to capture heterogeneity in soil temperature within the plot.

Both air and soil data loggers were installed on the first day of arrival on site and programmed to take a reading every 4 hours. Due to data loggers starting and finishing at different timeframes at each site (e.g. all 44 sites were not visited on the same day), only the microclimate data within the date range that all loggers were recording within have been used in analysis. The date range in which all sites were logging at the same time, and which was used for the analysis, was from 24, ${ }^{\text {th }}$ March 2018 to $18^{\text {th }}$ July 2018 ( $\sim 4$ months).

\subsubsection{Landscape Features Data Collection}

Using the Manaaki Whenua Landcare Research Landcover Database (LCDB v4.1), the landcover types within a $1 \mathrm{~km}$ radius of each site were calculated. Using ArcGIS desktop software, the 44 study sites were added to the LCDB v4.1 GIS layer and a $1 \mathrm{~km}$ radius polygon was placed over each site. The percentage cover of each landcover class within the $1 \mathrm{~km}$ polygon was calculated (e.g. Figure 5).

Individual landcover classes were grouped into two categories of either 'natural' or 'unnatural'. A complete list and description of landcover classes is provided in Appendix 1. Surrounding landcover composition varied considerably for each site with the total proportion of land-use classified as unnatural (which includes built up area, exotic forest, mixed exotic shrubland, urban parklands and production grasslands and croplands) ranging from 35-98\%. Total surrounding land-use that included natural cover classes (which includes indigenous forest and herbaceous freshwater and saline environments) ranged from $1.7-47 \%$ cover for each site. The marine environment (open water) was excluded from the analysis. Dunedin had the highest mean natural landcover surrounding its sites at 38\%, followed by Invercargill at $23 \%$ and Wellington at $22 \%$. However, due to the limited availability of forest restoration areas in Invercargill, 4 out of the 9 plots were established at one location on the outer limits of the peri- 
urban fringe. This results in a higher mean of surrounding natural landcover for this city. Definitions of landcover classes are provided in Appendix 1.

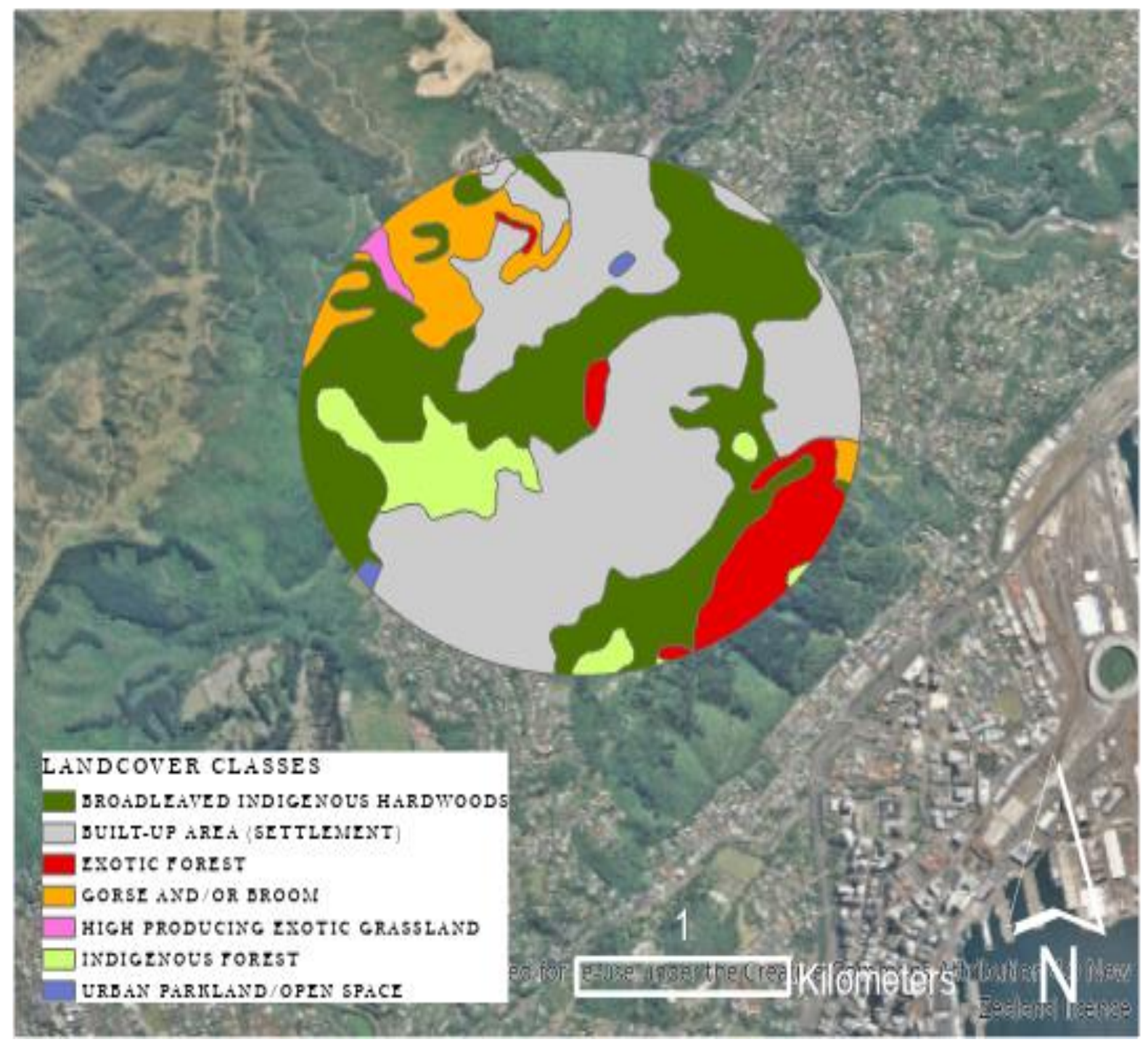

Figure 5: Example of a study site (Izard Park, Wellington) and its proportion of various landcover classes within a $1 \mathrm{~km}$ radius. Landcover classes and maps retrieved using $L C D B$ v4.1.

The most common historical land-use type for at least ten years prior to restoration activities at each site was agriculture (cultivation of land and breeding of animals and plants), which was the historical land-use for approximately $26 \%$ of the sites (Table 3). Shrubland (plant community characterised by vegetation dominated by shrubs, often also including grasses, herbs, and perennial plants) was the next most common at $25 \%$. The remaining categories: grassland, exotic forest and landfill made up the remaining $49 \%$ of the sites. Land-use history was determined using a combination of satellites images and discussions with land managers, owners and volunteers. 
Table 3: Urban forest restoration site information. City, site location, prior land-use, latitude, planting age and the proportion of surrounding natural landcover $<1 \mathrm{~km}$ radius of each site. Descriptions of each land-use type are provided in Appendix 1. Planting age is the age of the first plantings conducted on site by practitioners and was provided by relevant practitioners in each city via pers. comm.

\begin{tabular}{|c|c|c|c|c|c|}
\hline City & Site & $\begin{array}{l}\text { Prior Land- } \\
\text { use }\end{array}$ & $\begin{array}{r}\text { Latitude } \\
\left(\text { deg }^{\circ} \min ^{\prime} \text { sec }^{\prime \prime}\right)\end{array}$ & $\begin{array}{r}\text { Planting } \\
\text { Age (years) }\end{array}$ & $\begin{array}{r}\text { Natural Landcover } \\
(\%<1 \mathrm{~km} \text { radius })\end{array}$ \\
\hline \multirow[t]{9}{*}{ Wellington } & Manawa Karioi North & shrubland & $41.19^{\prime} 49^{\prime \prime}$ & 27 & 23 \\
\hline & Manawa Karioi South & shrubland & $41^{\circ} 19^{\prime} 51^{\prime \prime}$ & 27 & 22 \\
\hline & Mt Albert & grassland & $41^{\circ} 19^{\prime} 45^{\prime \prime}$ & 26 & 41 \\
\hline & Tawatawa Reserve & shrubland & $41^{\circ} 20^{\prime} 4^{\prime \prime}$ & 24 & 10 \\
\hline & Izard Park & exotic forest & $41^{\circ} 15^{\prime} 54^{\prime \prime}$ & 22 & 40 \\
\hline & Alexandra Road & grassland & $41^{\circ} 18^{\prime} 11^{\prime \prime}$ & 18 & 22 \\
\hline & Telford Terrace & exotic forest & $41^{\circ} 17^{\prime} 32^{\prime \prime}$ & 14 & 3 \\
\hline & Old Chest Hospital & exotic forest & $41^{\circ} 18^{\prime} 27^{\prime \prime}$ & 8 & 21 \\
\hline & Owen Street & exotic forest & $41^{\circ} 19^{\prime} \mathrm{O}^{\prime \prime}$ & 8 & 12 \\
\hline \multirow[t]{9}{*}{ Nelson } & Bobs Track & shrubland & $41^{\circ} 16^{\prime} 57^{\prime \prime}$ & 29 & 16 \\
\hline & Newman Grove & landfill & $41^{\circ} 15^{\prime} 31^{\prime \prime}$ & 28 & 13 \\
\hline & Waste Station & landfill & $41^{\circ} 17^{\prime} 34^{\prime \prime}$ & 28 & 18 \\
\hline & Whitehead Park & grassland & $41^{\circ} 15^{\prime} 57^{\prime \prime}$ & 20 & 26 \\
\hline & Murphy Reserve Old & exotic forest & $41^{\circ} 17^{\prime} 12^{\prime \prime}$ & 17 & 15 \\
\hline & Whakatu Drive & grassland & $41^{\circ} 18^{\prime} 24^{\prime \prime}$ & 16 & 17 \\
\hline & Titoki & agriculture & $41^{\circ} 14^{\prime} 15^{\prime \prime}$ & 13 & 31 \\
\hline & $\begin{array}{l}\text { Murphy Reserve } \\
\text { Young }\end{array}$ & shrubland & $41^{\circ} 17^{\prime} 6^{\prime \prime}$ & 8 & 16 \\
\hline & Pipers Reserve & exotic forest & $41^{\circ} 17^{\prime} 9^{\prime \prime}$ & 6 & 17 \\
\hline \multirow[t]{8}{*}{ Dunedin } & Craigieburn Old & shrubland & $45^{\circ} 50^{\prime} 29^{\prime \prime}$ & 59 & 44 \\
\hline & Signal Hill & exotic forest & $45^{\circ} 51^{\prime} 27^{\prime \prime}$ & 29 & 43 \\
\hline & Prospect Park & exotic forest & $45^{\circ} 51^{\prime} 22^{\prime \prime}$ & 21 & 34 \\
\hline & Upper Leith Walkway & shrubland & $45^{\circ} 51^{\prime} 8^{\prime \prime}$ & 21 & 44 \\
\hline & $\begin{array}{l}\text { Craigieburn } \\
\text { Intermediate }\end{array}$ & grassland & $45^{\circ} 50^{\prime} 30^{\prime \prime}$ & 18 & 44 \\
\hline & Frasers Gully & shrubland & $45^{\circ} 51^{\prime} 47^{\prime \prime}$ & 15 & 26 \\
\hline & Island Park & agriculture & $45^{\circ} 55^{\prime} 27^{\prime \prime}$ & 9 & 16 \\
\hline & Craigieburn Young & grassland & $45^{\circ} 50^{\prime} 29^{\prime \prime}$ & 7 & 43 \\
\hline \multirow[t]{9}{*}{ Christchurch } & Matawai & landfill & $43^{\circ} 18^{\prime} 58^{\prime \prime}$ & 43 & 3 \\
\hline & Riccarton Bush & exotic forest & $43^{\circ} 31^{\prime} 45^{\prime \prime}$ & 39 & 5 \\
\hline & Aynsley Terrace & agriculture & $43^{\circ} 33^{\prime} 43^{\prime \prime}$ & 28 & 5 \\
\hline & Wigram East & agriculture & $43^{\circ} 33^{\prime} 20^{\prime \prime}$ & 25 & 5 \\
\hline & Travis Wetland & agriculture & $43^{\circ} 29^{\prime} 11^{\prime \prime}$ & 18 & 46 \\
\hline & Halswell Quarry & agriculture & $43^{\circ} 35^{\prime} 54^{\prime \prime}$ & 17 & 3 \\
\hline & Styx Living Lab & agriculture & $43^{\circ} 27^{\prime} 16^{\prime \prime}$ & 15 & 4 \\
\hline & Marshland Road & agriculture & $43^{\circ} 27^{\prime} 4^{\prime \prime}$ & 12 & 1 \\
\hline & Radcliffe Road & agriculture & $43^{\circ} 27^{\prime} 53^{\prime \prime}$ & 7 & 1 \\
\hline \multirow[t]{2}{*}{ Invercargill } & Rance Covenant Old & agriculture & $46^{\circ} 27^{\prime} 4^{\prime \prime}$ & 22 & 36 \\
\hline & Estuary Walkway & landfill & $46^{\circ} 25^{\prime} 38^{\prime \prime}$ & 21 & 2 \\
\hline
\end{tabular}




\begin{tabular}{|c|c|c|c|c|}
\hline Kew Bush & shrubland & $46^{\circ} 26^{\prime} 24^{\prime \prime}$ & 19 & 14 \\
\hline $\begin{array}{l}\text { Rance Covenant } \\
\text { Young }\end{array}$ & agriculture & $46^{\circ} 27^{\prime} 5^{\prime \prime} \mathrm{O} 4$ & 18 & 36 \\
\hline Bushy Point Old & shrubland & $46^{\circ} 26^{\prime} 59^{\prime \prime}$ & 16 & 37 \\
\hline Bushy Point Young & agriculture & $46^{\circ} 26^{\prime} 52^{\prime \prime}$ & 12 & 40 \\
\hline Waihopi River & grassland & $46^{\circ} 23^{\prime} 20^{\prime \prime}$ & 11 & 12 \\
\hline $\begin{array}{l}\text { Thomsons Bush } \\
\text { Interior }\end{array}$ & grassland & $46^{\circ} 23^{\prime} 3^{\prime \prime}$ & 9 & 15 \\
\hline $\begin{array}{l}\text { Thomsons Bush } \\
\text { Exterior }\end{array}$ & grassland & $46^{\circ} 22^{\prime} 58^{\prime \prime}$ & 7 & 14 \\
\hline
\end{tabular}

\subsubsection{Species Traits Compilation}

A plant species trait list was compiled for nearly 200 species identified within the study, to enable analysis of trait-based patterns occurring within the restored forest communities (Table 4). A complete description of the traits used in the analysis is provided in Appendix 3.

Table 4: Trait types and categories compiled for species recorded within study.

\begin{tabular}{ll}
\hline Trait & Categories \\
\hline Status & native or exotic species \\
Structural Class & small tree $(<10 \mathrm{~m})$, medium tree $(10-20 \mathrm{~m})$, large tree \\
& $(20 \mathrm{~m}+)$ \\
& tree fern, shrub, ground fern, liane, epiphyte \\
Epiphytic & typical, occasional, hemi, ephemeral \\
Successional Stage & pioneer, early, mid, late \\
Shade Tolerance & low, moderate, high \\
Drought Tolerance & low, moderate, high \\
Primary Pollinator & insects, birds, wind, water, self \\
Primary Dispersal & birds, wind, water, ballistic, vegetative \\
Broad Fruit Type & dry, fruit, spore \\
\hline
\end{tabular}

Comprehensive collated resources containing trait classifications for native and exotic plant species are currently unavailable and a thorough search of literature, planting guides, websites and databases was necessary to assemble the required trait information for species identified in this study. Traits were recorded for each species if they were supported by published literature or appeared to be representative of the majority viewpoint expressed across multiple sources (including non-formal sources such as websites and personal communications). If trait information was conflicting between multiple sources, significant effort was made to gather data from as many resources as possible and the most commonly expressed expert opinion was used. After an initial trait classification spreadsheet was compiled, it was peer-reviewed by nine botanists, ecologists and restoration practitioners. Each reviewer was asked to assess the trait 
classifications assigned to plant species with which they were most familiar. Feedback was used to further refine trait data categorizations. There were no conflicting viewpoints received from reviewers.

\subsubsection{Summary of Ecosystem Variables Calculated for Analysis}

Various community measures were calculated for use in this study. These included species richness, plant abundance, plant trait, landscape and environmental measures (Table 5). These were calculated to track how planted urban forests develop over time; focusing on the planted canopy composition, physical environment and seedling regeneration. This provides some predictive power about when conditions are optimal for specific restoration activities; such as the appropriate timing for enrichment plantings and the creation of additional light wells.

Table 5: Ecosystem variables calculated within five conceptual frameworks. These frameworks include canopy $\Xi^{\circ}$ seedling tiers, site-level attributes, landscape-level factors and species-level plant traits.

\begin{tabular}{|c|c|c|c|c|}
\hline Canopy & Seedling & Site & Landscape & Plant traits \\
\hline $\begin{array}{l}\text { Stem abundance } \\
\left(\text { stems } / 200 m^{2}\right)\end{array}$ & $\begin{array}{l}\text { Stem abundance } \\
\left(\text { stems } / 7 \mathrm{Om}^{2}\right)\end{array}$ & $\begin{array}{l}\text { Leaf litter cover } \\
(\%)\end{array}$ & $\begin{array}{l}\text { Natural landcover } \\
(\%<1 \mathrm{~km} \text { radius })\end{array}$ & $\begin{array}{l}\text { Drought \& shade } \\
\text { tolerance } \\
\left(\text { species } / 200 m^{2}\right)\end{array}$ \\
\hline $\begin{array}{l}\text { Species richness } \\
(\text { species / 200m²) }\end{array}$ & $\begin{array}{l}\text { Species richness } \\
\left(\text { species } / 70 \mathrm{~m}^{2}\right)\end{array}$ & $\begin{array}{l}\text { Herbaceous ground } \\
\text { cover } \\
(\%)\end{array}$ & & $\begin{array}{l}\text { Pollinator } \\
\text { strategies } \\
\left(\text { species } / 200 \mathrm{~m}^{2}\right)\end{array}$ \\
\hline $\begin{array}{l}\text { Diversity } \\
\left(200 \mathrm{~m}^{2}\right)\end{array}$ & $\begin{array}{l}\text { Diversity } \\
\left(70 \mathrm{~m}^{2}\right)\end{array}$ & $\begin{array}{l}\text { Daily air temperature } \\
\text { (range in }{ }^{\circ} \mathrm{C} \text { ) }\end{array}$ & & $\begin{array}{l}\text { Dispersal strategies } \\
\left(\text { species } / 200 \mathrm{~m}^{2}\right)\end{array}$ \\
\hline $\begin{array}{l}\text { Basal area } \\
\left(\mathrm{m}^{2} / \mathrm{ha}\right)\end{array}$ & & $\begin{array}{l}\text { Daily soil temperature } \\
\text { (range in }{ }^{\circ} \mathrm{C} \text { ) }\end{array}$ & & $\begin{array}{l}\text { Reproductive traits } \\
(\text { species / 200m²) }\end{array}$ \\
\hline $\begin{array}{l}\text { Light transmittance } \\
(\%)\end{array}$ & & $\begin{array}{l}\text { Planting age } \\
\text { (years) }\end{array}$ & & $\begin{array}{l}\text { Structural Class } \\
(\text { species / 200m²) }\end{array}$ \\
\hline $\begin{array}{l}\text { Canopy height } \\
(\mathrm{m})\end{array}$ & & $\begin{array}{l}\text { Land-use history } \\
\text { (category) }\end{array}$ & & $\begin{array}{l}\text { Successional status } \\
\left(\text { species } / 200 \mathrm{~m}^{2}\right)\end{array}$ \\
\hline
\end{tabular}

\subsubsection{Data Preparation and Analysis}

All analyses in chapter 2 and 3 were conducted using R statistical software version 3.6.1 and plots were created using the $\mathrm{R}$ base package (R Core Team, 2013). The experimental unit and statistical unit used in these analyses was at the plot level.

\section{$\underline{\text { Diversity Index }}$}

The ‘vegan' package (Oksanen et al., 2019) and Shannon-Weaver diversity index was used to calculate species diversity within the canopy and seedling communities. The Shannon's index 
accounts for both abundance and evenness of the species present (Magurran, 2003). For this calculation, the proportion of a single given species relative to the total number of species in the sample (i.e. plot) is calculated. This is then multiplied by the natural logarithm of this proportion. The resulting process is completed for each species in the sample, then summed across all the species and multiplied by -1 .

\section{$\underline{\text { Basal area }}$}

Basal area was calculated from stem DBH measures. To do this, the following steps were taken: 1) calculate the area of each individual tree in the plot $\left.\left(\pi(\mathrm{DBH} / 2)^{2}\right), 2\right)$ sum the areas to get the total area $\left(\right.$ in $\mathrm{cm}^{2}$ ) of trees in the plot, 3) convert the total to $\mathrm{m}^{2}$ by dividing by $10,000,4$ ) scale it up to the hectare level by multiplying by 50 .

\section{$\underline{\text { Light transmittance }}$}

Light transmittance readings were taken during two separate site visits at 5 locations resulting in 10 separate light transmittance readings for each site. To use these data, the 10 readings were averaged to get a single average light transmittance reading for each site.

\section{Leaflitter \& Herbaceous Cover}

Herbaceous cover and leaf litter cover were estimated as a percentage cover within each subplot. To get an average estimate of cover for these two variables across each entire plot, the 8 separate readings were averaged.

\section{Microclimate}

Data loggers were recording air and soil temperature for a period of nearly four months. The readings were converted to the average daily range (difference between daily minimum and daily maximum). This was done by first calculating both the average daily minimum and average daily maximum temperatures that occurred during the 4 months data loggers were recording for. Then the range recorded for our analysis was the difference between these two figures. This resulted in a single average daily range in ${ }^{\circ} \mathrm{C}$ for each site. 


\subsection{Introduction}

Historical and contemporary urban expansion has resulted in the substantial removal of native forests from urban landscapes (Carreiro et al., 2008). This has led to a global demand for the implementation of ecological restoration activities to reconstruct native forests within these degraded urban areas (Aronson \& Alexander, 2013). Over the last few decades, efforts to reestablish urban forest species within degraded urban landscapes to improve ecosystem services, function, resilience and biodiversity have been increasing (Prach \& Walker, 2011). In New Zealand, despite numerous forest restoration programmes being implemented across many cities, long-term monitoring to assess whether restoration programmes have been successful in building forest successional trajectories aimed towards self-sustaining and ecologically functioning urban plant communities are rarely undertaken. This means that the timeframes in which key compositional, structural and ecological shifts occur within these restored urban forests are largely unknown (Herrick et al., 2006). Therefore, it is unclear whether the outcomes of these restoration programmes can be deemed ecologically successful.

While the establishment of planted early successional forest canopies is thought to be relatively successful in restoration programmes throughout New Zealand; a trajectory towards development of a vegetation assemblage with natural components related to form, function and stability, all fundamental attributes of fully-recovered forests (Proença et al., 2012), is rare. If restoration programmes are to be successful, action must go beyond a focus on just planting trees with the aim for improvement of the appearance of a site (Keesing \& Wratten, 1998; Mansourian et al., 2005). Instead, practitioners must include goals to restore biological interactions, processes and integrity (Reay \& Norton, 2002; Ruiz-Jaén \& Aide, 2006; Saunders \& Hobbs, 1995); and connectivity to the wider landscape (Peña-Domene et al., 2016; Tambosi et al., 2014). Approaches to how practitioners restore urban forests depends on a range of factors including the degree of degradation at the restoration site, residual vegetation, site isolation, project scale and resources available for ongoing maintenance (Sullivan et al., 2009). However, as much as feasible practitioners must consider the wide variety of ecological elements that require restoration to achieve ecological integrity. Ecological elements that are commonly missing from restored urban forest communities include the reinstatement of structural canopy and subcanopy layers, spatial habitat diversity, diverse plant phylogenetics and life-forms, landscape linkages, plant reproduction, resilience to stressors, self- 
sustainability, and interactions between flora, fauna (especially insects and micro-organisms) and environment (Herrick et al., 2006; Norton et al., 2018). Keesing and Wratten (1998) state that the challenge of restoration programmes is the need for an understanding and utilization of ecological succession to complement and accelerate the processes of natural colonisation and regeneration. Reay and Norton (2002) further explain that recreating structure and composition without restoring function, or recreating function in the absence of structure and composition, fails to constitute as complete restoration. Restoration success could be seen as a human-initiated successional sequence, starting at the initial establishment of plantings of trees and shrubs, followed by continued intervention to fully establish attributes that ensure a selfsustaining and functioning forest ecosystem.

Numerous studies have described the patterns of natural forest succession (Allen et al., 2013b; Wyse et al., 2018). These studies have shown shrub species to often occur in higher densities in early successional stages and long-lived canopy species which tend to increase during late succession (Chazdon et al., 2010). Studies have also demonstrated that successional shifts are seen within vegetation life-forms, which include differences in growth forms, life-history traits and morphology (Asanok et al., 2013; Chazdon et al., 2010). For example, highly drought tolerant shrubs are more prominent in the early successional stage and a transition occurs to more highly shade tolerant species once canopy cover is established during mid succession $(\mathrm{Fu}$ et al., 2009). Research shows that species interactions are dynamic due to differing growth rates, tolerances and vulnerabilities, which lead to rolling changes in dominant species composition (i.e. succession) and complementary effects (Forrester, 2014). These shifts in species dominance are primarily driven by autogenic changes such as availability of light, water and nutrients (Smith \& Huston, 1989) and secondary allogenic factors such as regional species pool, soil seed bank, propagule sources and species interactions (Guariguata \& Ostertag, 2001). However, studies looking into the temporal dynamics of fully reconstructed urban forests are uncommon (Escobedo et al., 2016), and it is essential to review whether current New Zealand restoration strategies are sufficient to restore ecologically functioning plant communities which have processes and patterns as similar as feasible (given the site conditions) to rural, undisturbed, naturally regenerating forest ecosystems. When planning to restore urban forests where the structure is multi-aged, stratified and contains critical ecological processes such as seedling germination, it is necessary to understand the various complex dynamic relationships occurring over decadal timescales (Wingard et al., 2017). It has been highlighted that temporal changes in canopy development and physical site characteristics within urban forests can vary depending on surrounding pressures on the site, conditions over decadal timescales, initial 
planting strategies and long-term management decisions (Rappaport et al., 2015). For example, a recent study revealed that the simultaneous planting of native trees, commonly executed in restoration programmes, does not necessarily lead to a natural forest structure; and instead can lead to artificial cohorts which are rarely observed in more natural forest ecosystems (Hotta et al., 2015).

Considering that urban forest development and successional processes appear to be strongly dependent on initial site conditions, planted community composition and ongoing management decisions, restoration practitioners need information on how their short-term and long-term strategies will affect the trajectory of the restoration site and resulting goal of creating a selfsustaining urban forest. While the theoretical framework of ecological succession underpins many aspects of restoration ecology and generalizations surrounding trajectories are well studied (Mark et al., 1989; Trudgill, 2012; van Breugel et al., 2007; Wilson et al., 1992), practitioners do not often utilise this information comprehensively when undertaking urban forest reconstruction programmes. In order to achieve a holistic approach to the reconstruction of urban forest ecosystems, barriers hindering the development of planted forest communities into near-natural ecological-intact urban forest ecosystems need to be considered. With enrichment activities taking place to alter the forest trajectory if monitoring highlights concerns.

\subsubsection{Objective}

The objective of this chapter is to highlight broad temporal trends in the development of urban forest restoration sites in New Zealand. Primary goals of this chapter are to investigate 1) the temporal trends of planted urban forest canopy development, and 2) temporal changes in the understorey or forest floor dynamics of restored forests. This information will help address critical questions such as: how long does it take planted canopies to reach high levels of diversity, species richness and stem abundance? Or, around what time-frame can we expect canopy closure to occur? And, how many years post planting can we achieve a high level of leaf litter cover or a reduction in daily temperature extremes? And finally, what dominant plants traits are present within the forest canopies? These results will provide a big-picture perspective on the strategies to consider when implementing restoration programmes, and predictive power about when conditions are optimal for specific restoration activities such as enrichment plantings and adaptive management actions such as the creation of artificial light wells. 


\subsection{Methods}

For a description of general methodologies regarding research preparation and set up, field methods, data collection, research variables and data preparation and analysis, please refer to Chapter 1. Discussed here are the methods used specifically for data analysis in this chapter, answering questions surrounding temporal trends. The vegetation data used for this chapter are those of the trees $(>2.5 \mathrm{~cm} \mathrm{DBH},>1.35 \mathrm{~m}$ tall $)$ and shrubs $(<2.5,<1.35 \mathrm{~m}$ tall $)$.

\subsubsection{Data Analysis}

The independent variable of interest in these analyses is planted forest age (years since planting). The response variables were split into two groups: the forest canopy and understory and forest floor. Response variables representing canopy tree dynamics included: stem abundance, species richness, diversity, height, basal area, light transmittance, structural classes and successional stage traits (see Table 5). Response variables representing changes in forest floor dynamics and microclimate included leaf litter cover, herbaceous cover, soil temperature and air temperature.

\section{$\underline{\text { Linear Regression }}$}

Linear regression models (LM) were used to test the effect of forest planting age on the twelve response variables listed above. All response variable data were transformed using a $\log 10$ transformation due to non-normal data distribution, which corrected the issue of nonnormality in all instances. Probability values (p-value), adjusted R-squared (adj. $\mathrm{R}^{2}$ ) and akaike information criterion (AIC) values were retrieved from the fitted linear regression models. These statistics were used to assess how well the model fitted the data, whether it was statistically significant, and to compare the quality of the linear model to the next model including breakpoints. If linear regression models were the preferred model (lower AIC), these were chosen to display graphically in the results section. 95\% confidence intervals were plotted on graphs only if the $\mathrm{R}^{2}$ value was equal to or over 0.20 and p-values were added to graphs only if they were significant $(\mathrm{p}<0.05)$.

\section{$\underline{\text { Breakpoint Analysis }}$}

Breakpoint analysis was used to look for possible thresholds in forest development. Once a linear regression model was fitted, a second model was fitted using the 'segmented' package (Ostertag et al., 2015). A segmented relationship is defined by the slope parameters and the 
break-point(s) where the linear slope changes significantly relative to the next segment in the line. Statistical analysis allowed the R code run to self-select the number of breakpoints present within the model and outputs always resulted in only 1 significant breakpoint. Breakpoint models are displayed graphically in the results section if they had a lower AIC value than the normal, initially produced LM for the same variables. Confidence intervals where plotted with breakpoint regression lines if the adj. $\mathrm{R}^{2}$ value was equal to or over 0.20. Relationships with adj. $\mathrm{R}^{2}$ values less than 0.20 were considered not to represent the data well.

\section{Nonmetric Multidimensional Scaling}

To examine species similarity among plots, Bray-Curtis similarity scores were calculated for canopy communities. Kruskals nonmetric multidimensional scaling (NMDS) was used to represent community variation between study sites. NMDS uses information on the abundance of each species to examine community similarity in two dimensional composite variable space (Clarke \& Warwick 2001). Species' abundance was input as the untransformed number of stems per plot (canopy community). The analysis was performed using both 'Vegan' and 'labdsv' packages (Oksanen et al, 2013; Roberts, 2019) within R statistical software (R Core Team, 2013). The age since planting and city of each site were visualised using coloured labels and point symbols, respectively, in the two dimensional NMDS plots.

\section{$2.3 \quad$ Results}

Within the forest canopies, a total of 79 woody species from 33 plant families were identified in this study. Out of those, native trees represented 25 plant families and 54 species and native shrubs encompassed 5 families and 10 species. Three tree species (Pittosporum tenuifolium, Pittosporum eugenioides, Cordyline australis) were found at $50 \%$ of the sites, and a further seven species were recorded in over $25 \%$ of the sites (Table 6). Thirty-two tree species were fairly uncommon and present in less than $5 \%$ of the sites. The tree species with the highest total abundance across all 44 sites were Cordyline australis with 339 individuals (ind.) recorded, followed by Pittosporum tenuifolium (329 ind.), Myoporum laetum (143 ind.), Pittosporum eugenioides (120 ind.), Griselinia littoralis (137 ind.) and Melicytus ramiflorus with 125 stems (Table 6). Only three native tree species of late successional status were found throughout the canopies of the restoration plantings, which were Dysoxylum spectabile, Elaeocarpus dentatus and Prumnopitys ferruginea. The most commonly found shrub species were those from the Coprosma and Hebe (Veronica) genera. 
Table 6: The top 10\% of woody species found at the highest number of study sites. Species are ranked in order of the most widely distributed across sites. Number of stems is the total count for each species across all 44 study sites. Associated traits for these species are provided.

\begin{tabular}{|c|c|c|c|c|c|c|}
\hline Woody Species & $\begin{array}{l}\text { Structural } \\
\text { Class }\end{array}$ & $\begin{array}{l}\text { Successional } \\
\text { Class Range }\end{array}$ & $\begin{array}{l}\text { Shade } \\
\text { Tolerance }\end{array}$ & $\begin{array}{l}\text { Drought } \\
\text { Tolerance }\end{array}$ & $\begin{array}{r}\text { № of Sites } \\
\text { Where Present }\end{array}$ & $\begin{array}{r}\text { № of } \\
\text { Stems }\end{array}$ \\
\hline Pittosporum tenuifolium & Small tree & Early-mid & Moderate & High & 34 & 325 \\
\hline Pittosporum eugenioides & Med tree & Early-late & Moderate & Moderate & 29 & 120 \\
\hline Cordyline australis & Med tree & $\begin{array}{l}\text { Pioneer- } \\
\text { early }\end{array}$ & Moderate & High & 28 & 339 \\
\hline Griselinia littoralis & Med tree & Early-late & Moderate & High & 20 & 128 \\
\hline Coprosma robusta & Small tree & Early-mid & High & Moderate & 17 & 117 \\
\hline $\begin{array}{l}\text { Melicytus ramiflorus } \\
\text { subsp. ramiflorus }\end{array}$ & Med tree & Early-mid & Moderate & Moderate & 16 & 125 \\
\hline Kunzea robusta & Large tree & Pioneer-mid & Low & High & 14 & 97 \\
\hline Myoporum laetum & Med tree & Early-mid & Moderate & High & 14 & 143 \\
\hline $\begin{array}{l}\text { Podocarpus totara var. } \\
\text { totara }\end{array}$ & Large & Early-late & Moderate & High & 14 & 47 \\
\hline Hoheria angustifolia & Med tree & Early-mid & Moderate & High & 12 & 63 \\
\hline $\begin{array}{l}\text { Plagianthus regius } \\
\text { subsp. regius }\end{array}$ & Med tree & Early-late & Moderate & Moderate & 12 & 95 \\
\hline Aristotelia serrata & Small tree & $\begin{array}{l}\text { Pioneer- } \\
\text { early }\end{array}$ & Moderate & Low & 10 & 53 \\
\hline Veronica salicifolia & Shrub & Early & Low & Moderate & 10 & 36 \\
\hline Pseudopanax crassifolius & Med tree & Early-late & Moderate & Moderate & 8 & 11 \\
\hline Dodonaea viscosa & Med tree & Pioneer-mid & Low & High & 7 & 51 \\
\hline $\begin{array}{l}\text { Leptospermum scoparium } \\
\text { var. scoparium }\end{array}$ & Small tree & $\begin{array}{l}\text { Pioneer- } \\
\text { early }\end{array}$ & Low & High & 7 & 46 \\
\hline Pittosporum crassifolium & Small tree & Early-mid & Moderate & High & 7 & 105 \\
\hline Coprosma lucida & Shrub & $\begin{array}{l}\text { Pioneer- } \\
\text { early }\end{array}$ & High & Moderate & 3 & 13 \\
\hline
\end{tabular}

We identified 15 exotic woody species, but these represented a very small proportion of total canopy species across all sites, with only 83 exotic trees and shrubs counted in total compared to the 2389 native trees and shrubs recorded (3.4\%). The most abundant exotic tree species was Chamaecytisus palmensis with 10 individuals recorded. The most abundant shrub species were Berberis darwinii with 42 individuals, however most of these were located at a single site (Signal Hill) within the city of Dunedin.

Wellington had the highest total number of plant families, species richness; stem abundance; and the lowest average basal area (Table 7). Dunedin had one study site less than the rest of the cities within the study, however still had the same number of woody species and plant families as Nelson. Christchurch had the highest basal area out of the five cities. Invercargill had the highest average light transmittance at $42 \%$ and highest shrub count. Nelson had the lowest count of total woody stems compared to the other four cities. 
Table 7: Summary of canopy plant data for each city. The total count of all woody plants is provided, with separate totals for trees (1.t number) and shrubs (2nd number) in brackets. Trees and shrubs are life form classifications for each species (sourced from NZPCN, Appendix 3). Basal area ( $m^{2}$ per hectare) is averaged across all plots within each city.

\begin{tabular}{lrrrrrr}
\hline City & $\begin{array}{r}\text { № of } \\
\text { Plots }\end{array}$ & $\begin{array}{r}\text { Age Range of Plots } \\
\text { (years) }\end{array}$ & $\begin{array}{r}\text { Basal Area } \\
\text { (m2 / ha) }\end{array}$ & $\begin{array}{r}\text { № of } \\
\text { Families }\end{array}$ & $\begin{array}{r}\text { № of } \\
\text { Species }\end{array}$ & $\begin{array}{r}\text { № of } \\
\text { Individuals }\end{array}$ \\
\hline Wellington & 9 & $8-27$ & 216.64 & $20(19,5)$ & $34(30,4)$ & $578(565,13)$ \\
Nelson & 9 & $6-29$ & 241.41 & $18(18,0)$ & $26(26,0)$ & $260(260,0)$ \\
Dunedin & 8 & $7-59$ & 394.12 & $18(17,2)$ & $26(25,1)$ & $460(458,2)$ \\
Christchurch & 9 & $7-43$ & 352.51 & $15(14,4)$ & $28(23,5)$ & $528(503,25)$ \\
Invercargill & 9 & $7-22$ & 241.97 & $16(15,4)$ & $25(21,4)$ & $506(457,49)$ \\
\hline
\end{tabular}

The results of the NMDS suggest that canopy composition of trees $>2.5 \mathrm{~cm} \mathrm{DBH}$ at a site differs among cities more so than by planting age. The NMDS plot shows some clustering of sites within cities (Figure 6). In particular, Dunedin City had a strong clustering and the cities of Christchurch and Invercargill also had fairly clustered groupings with the exception of a couple of outliers. However, it should be noted that the stress value of $2.3 \%$ is just outside the recommended range (Clarke \& Warwick 2001), hence the representation of points in the twodimensional plot should not be entirely relied on.

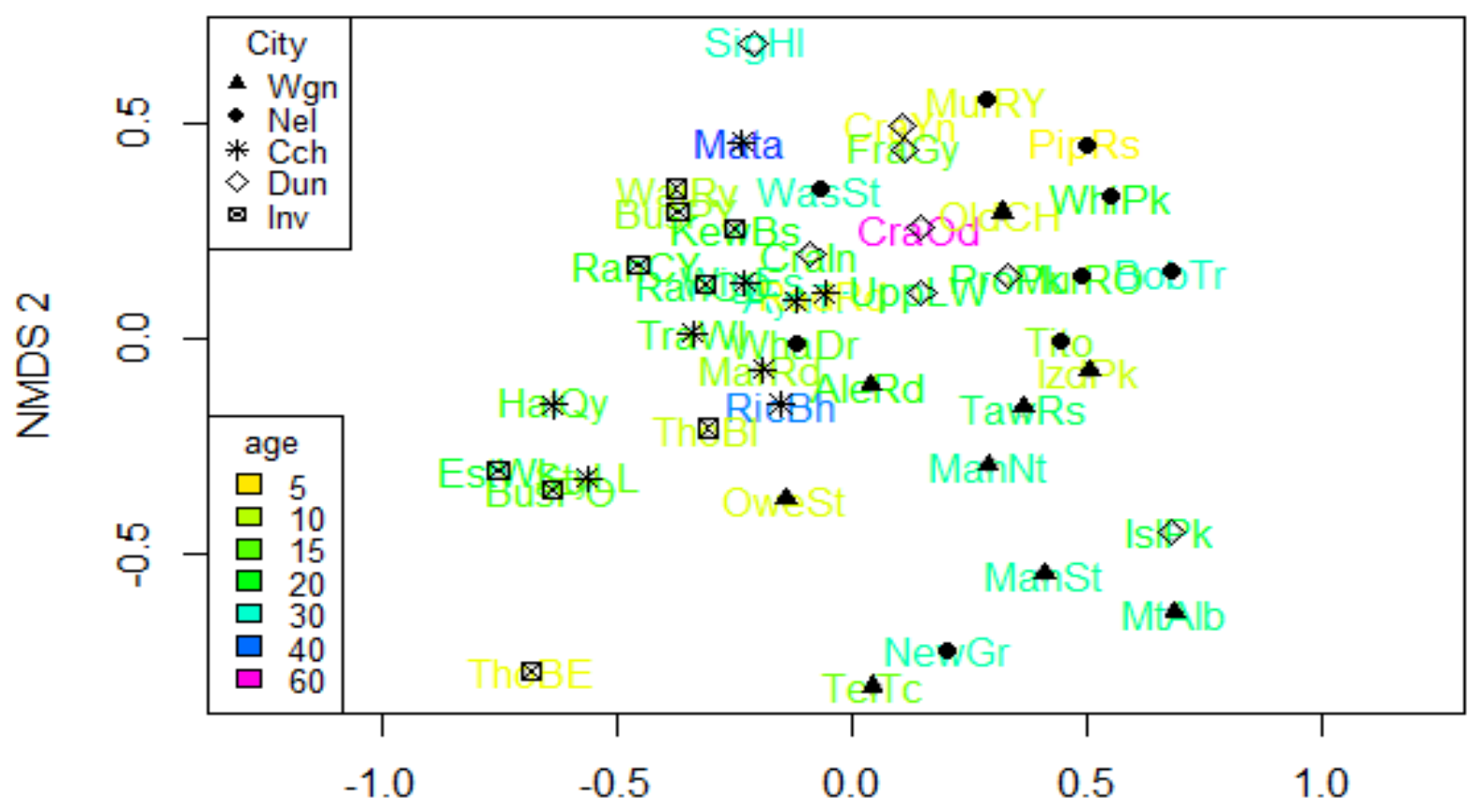

NMDS 1

Figure 6: A two-dimensional NMDS ordination of the differences in canopy species composition across five cities and a forest age chronosequence based on Bray-Curtis similarities (stress = 0.23). City codes are: Wellington (Wgn), Nelson (Nel), Christchurch Cch), Dunedin (Dun) and Invercargill (Inv). 


\subsubsection{Forest Canopy Development}

Native woody plant abundance ranged from 3 to 132 individuals per site $\left(200 \mathrm{~m}^{2}\right)$ and basal area from 0.2 to $64 \mathrm{~m}^{2}$ per hectare (Figure $7 \mathrm{a}$, Figure $7 \mathrm{~d}$ ). The linear regression models showed a significant increase in native stem abundance and basal area $(p<0.01$ and $p<0.0001$ respectively) with forest planting age (Table 8). Exotic stem abundance was lower than native abundance across all study sites, however three exotic species were commonly found at sites under 10 years old, these were Chamaecytisus palmensis, Salix cinerea, and Cytisus scoparius. Native species richness increased significantly with age $(\mathrm{p}<0.001)$, with a range of 1 to 17 species across all plots. Woody species diversity across all plots ranged from 0-2.5, however there was no significant relationship with forest age. Both light transmittance and canopy height had the most significant relationship with forest planting age (both $\mathrm{p}<0.0001$ ), with light transmittance decreasing and canopy height increasing with age. Average canopy height across all sites ranged from $3 \mathrm{~m}$ to $15 \mathrm{~m}$.

Breakpoints along the chronosequence occurred for stem abundance and species richness within the first 12 years of forest development (Figure 7a, Figure 7b) but only stem abundance was significant $(\mathrm{p}<0.01)$. At approximately 12 years of forest growth, when a breakpoint occurred, the forests reached an abundance of 60 individuals and species richness of 8 . After this point, stem abundance plateaus, but species richness continues to increase slightly over the remaining decades.

Canopy height and basal area took longer to reach a breakpoint, occurring around 17 years post planting. Both variables developed similarly, increasing most dramatically during the first 16-18 years of forest growth (both $\mathrm{p}<0.0001$ ) with canopy height reaching $10 \mathrm{~m}$ and basal area $40 \mathrm{~m}^{2} /$ ha at this breakpoint (Figure $7 \mathrm{~d}$, Figure $7 \mathrm{e}$ ). It took 20 years for light transmittance to drop sharply from $80 \%$ to $15 \%$, at which point a breakpoint occurs $(\mathrm{p}<0.0001)$ and then light transmittance plateaus (Figure $7 \mathrm{f}$ ).

(a)

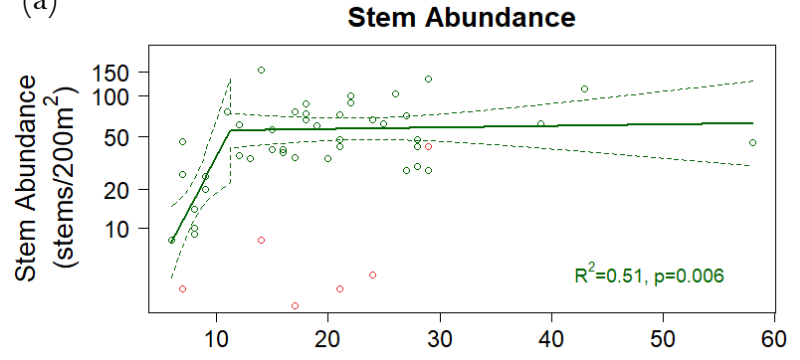

(b)

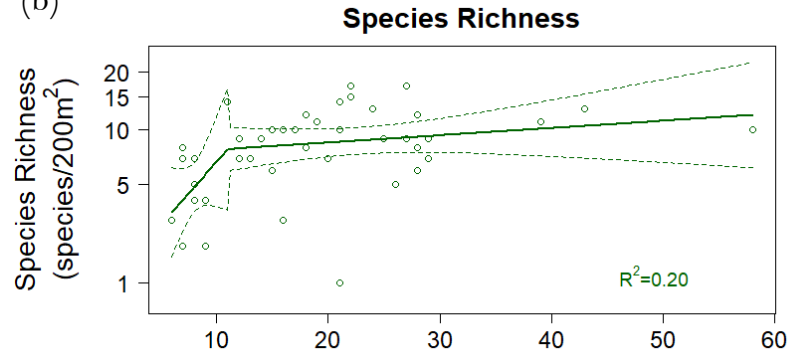


(c)

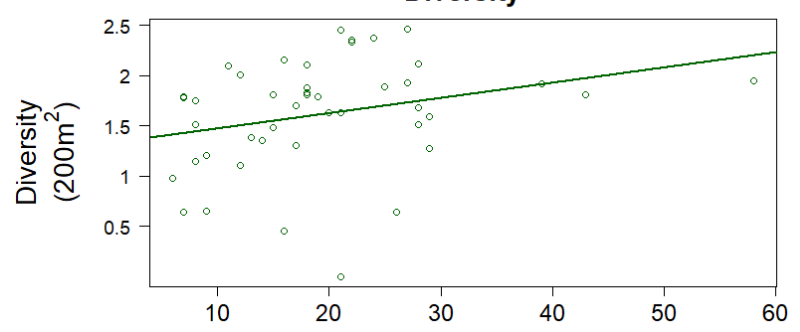

(e)

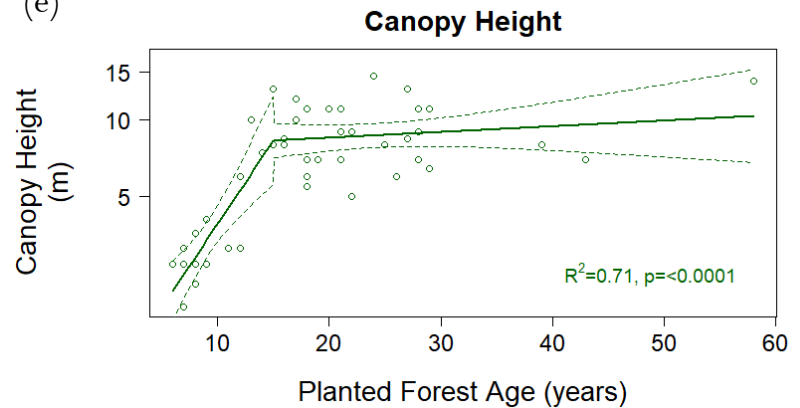

(d)

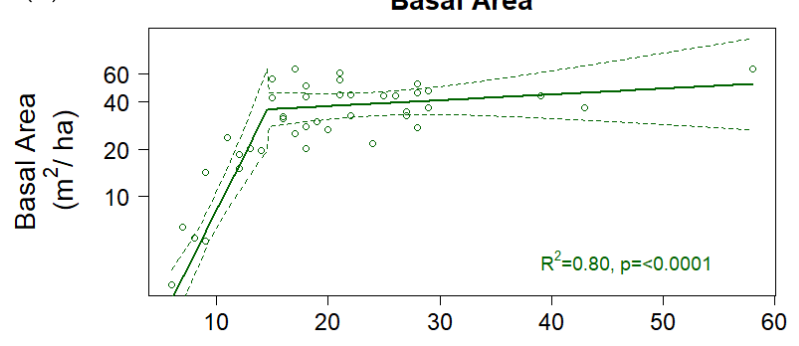

(f)

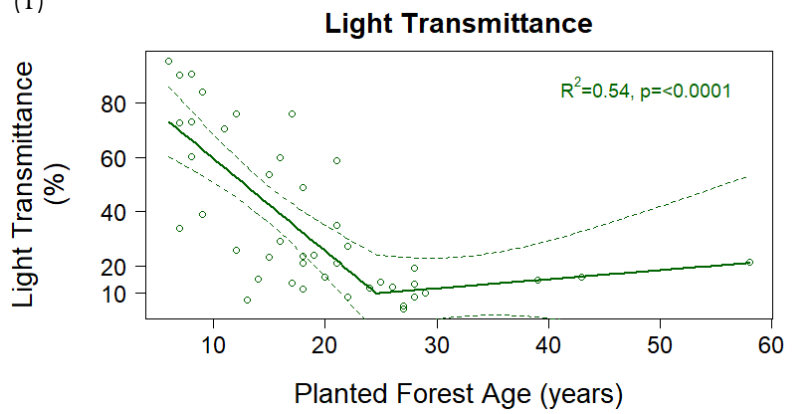

Figure 7: Linear regression models for forest development across a planting age chronosequence, focusing on woody species (trees and shrubs). Plots show changes in a) abundance, b) species richness, d) total basal area, e) average canopy height, and f) average light transmittance. Linear regression analysis without breakpoints was the preferred model for species diversity (c). The red points in figures a and b are the abundance and species richness of exotic species. However, a linear model was not fit to either of these variables due to a lack of data points. All variables except diversity and light transmittance were log transformed. All models were significant except diversity.

Table 8: Regression analysis of the effect offorest age on canopy abundance, species richness, diversity, basal area, light transmittance and height. Models with the lower AIC are displayed in the results section above. Canopy abundance, species richness and diversity measured per plot (200m $)^{2}$. The p-value and beta estimates for the breakpoint analysis represents the significance of the first slope in the model. The second slope in all breakpoint models were not significant. In all cases $n=44$. Significance codes: $*=p<0.05$, ** $=p<0.01$, *** $=p<0.001$, ***** $=p<0.0001$.

\begin{tabular}{|c|c|c|c|c|c|c|}
\hline Response Variable & $\begin{array}{l}\text { Statistical } \\
\text { Analysis }\end{array}$ & $\begin{array}{r}\text { Beta } \\
\text { Estimate }\end{array}$ & AIC & $\Delta \mathrm{AIC}$ & Adjusted $\mathbf{R}^{2}$ & $P$-value \\
\hline \multirow{2}{*}{$\begin{array}{l}\text { Abundance } \\
\left(\text { stems } / 200^{2}\right)\end{array}$} & Breakpoint & 0.153 & -148.32 & O & 0.51 & $0.006 * *$ \\
\hline & Linear Model & 0.013 & -139.72 & 8.6 & 0.14 & $0.005 * *$ \\
\hline \multirow{2}{*}{$\begin{array}{l}\text { Species Richness } \\
\left(\text { stems } / 200 m^{2}\right)\end{array}$} & Breakpoint & 0.057 & -16.49 & o & 0.20 & 0.176 \\
\hline & Linear Model & 0.007 & -14.75 & 1.74 & 0.13 & $0.007 * *$ \\
\hline \multirow{2}{*}{$\begin{array}{l}\text { Diversity } \\
\left(200 \mathrm{~m}^{2}\right)\end{array}$} & Linear Model & 0.015 & -74.07 & o & 0.05 & 0.062 \\
\hline & Breakpoint & 0.032 & -76.41 & 2.34 & 0.04 & 0.095 \\
\hline \multirow{2}{*}{$\begin{array}{l}\text { Basal Area } \\
\left(\mathrm{m}^{2} / \mathrm{ha}\right)\end{array}$} & Breakpoint & 0.130 & -13.48 & o & 0.80 & $1 \mathrm{e}-07 * * * *$ \\
\hline & Linear Model & 0.026 & 34.41 & 20.93 & 0.38 & $3 \mathrm{e}-06 * * * *$ \\
\hline \multirow{2}{*}{$\begin{array}{l}\text { Light Transmittance } \\
(\%)\end{array}$} & Breakpoint & -3.738 & 388 & o & 0.54 & $2 \mathrm{e}-06 * * * *$ \\
\hline & Linear Model & -1.616 & 402 & 14 & 0.35 & $1 \mathrm{e}-05 * * * *$ \\
\hline Canopy Height & Breakpoint & 0.055 & -62.07 & o & 0.71 & $2 \mathrm{e}-05 * * * *$ \\
\hline
\end{tabular}


Changes in canopy species trait dominance were analysed using plant trait data (Table 4, Appendix 3). Species richness of early successional plants increased significantly with age $(\mathrm{p}<0.05$, Table 9$)$ in the linear model, and were on average $2-4$ times more dominant across the chronosequence, than pioneer species (Figure 8a). Only five sites had more than two pioneer species present and only two restoration sites had more than two mid-successional species. There is a similar linear trend with age for species of small and large-sized trees (Figure 8b) although small trees are twice as species-rich. Very few shrubs species are either being planted, arriving or surviving and tree ferns were non-existent across all sites. Only five sites contained shrub species and within these, the maximum number of shrub species found was only two. Medium-sized tree were more dominant than all other height classes and their species richness had a significant positive linear relationship with forest age $(\mathrm{p}<0.001)$. Breakpoint models were selected over linear models to describe the chronosequence for pioneer successional and medium-sized woody species. However, the breakpoint was only significant for medium-sized tree species $(\mathrm{p}<0.01)$.

(a)
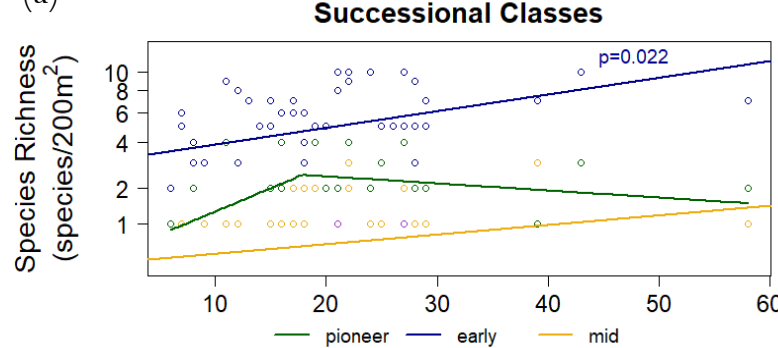

Planted Forest Age (years) (b)

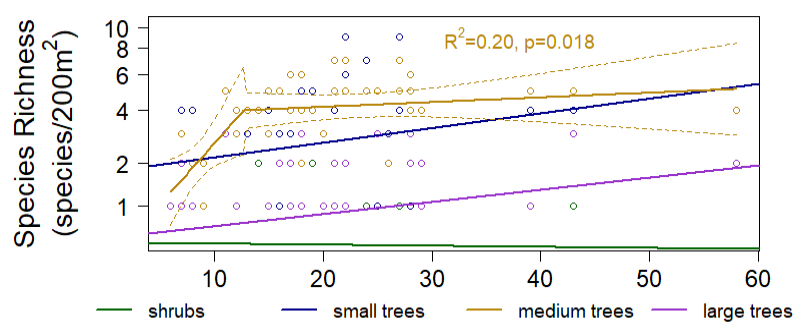

Planted Forest Age (years)

Figure 8: Linear regression models for changes in canopy species traits (successional stage and maximum height class) across a planted forest chronosequence. Plots show changes in species richness within a) successional class and b) structural class. All trait categories fitted linear models except for pioneer successional species and mediumsized tree species which had breakpoints. Purple points within the successional class plot represent late successional species which a linear model would not fit to due to a lack of data points. Only pioneer and medium sized tree species had significant models.

Table 9: Regression analysis of the effect of forest age on species richness of canopy species traits from different structural and successional guilds. Models with the lower AIC are displayed in the results section above. Species richness measured per plot $\left(200 m^{2}\right)$. The p-value and beta estimates for the breakpoint analysis represents the 
significance of the first slope in the model. The second slope in all breakpoint models were not significant. In all

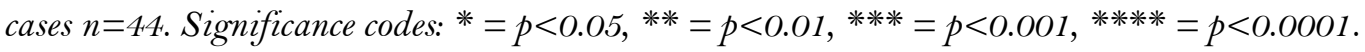

\begin{tabular}{|c|c|c|c|c|c|c|}
\hline Response Variable & $\begin{array}{l}\text { Statistical } \\
\text { Analysis }\end{array}$ & $\begin{array}{r}\text { Beta } \\
\text { Estimate }\end{array}$ & AIC & $\Delta \mathrm{AIC}$ & Adjusted $R^{2}$ & P-value \\
\hline \multirow{2}{*}{$\begin{array}{l}\text { Shrubs } \\
\left(\text { species } / 200 m^{2}\right)\end{array}$} & Linear Model & -0.000 & -20.03 & O & -0.02 & 0.856 \\
\hline & Breakpoint & -0.044 & 19.78 & 39.81 & 0.01 & 0.532 \\
\hline \multirow{2}{*}{$\begin{array}{l}\text { Small Trees }<10 \mathrm{~m} \\
\left(\text { species } / 200 \mathrm{~m}^{2}\right)\end{array}$} & Linear Model & 0.006 & -0.75 & o & 0.05 & 0.077 \\
\hline & Breakpoint & 0.034 & 0.98 & 1.73 & 0.05 & 0.286 \\
\hline \multirow{2}{*}{$\begin{array}{l}\text { Medium Trees 10-20m } \\
\left(\text { species } / 200 m^{2}\right)\end{array}$} & Breakpoint & 0.048 & -43.88 & o & 0.37 & $0.018 *$ \\
\hline & Linear Model & 0.007 & -34.90 & 8.98 & 0.20 & $0.001 * * *$ \\
\hline \multirow{2}{*}{$\begin{array}{l}\text { Large Trees } 20 \mathrm{~m}+ \\
\left(\text { species } / 200 \mathrm{~m}^{2}\right)\end{array}$} & Linear Model & 0.005 & -7.73 & $\mathrm{O}$ & 0.03 & 0.114 \\
\hline & Breakpoint & 0.060 & -5.03 & 2.7 & 0.01 & 0.497 \\
\hline \multirow{2}{*}{$\begin{array}{l}\text { Pioneer } \\
\left(\text { species } / 200 m^{2}\right)\end{array}$} & Breakpoint & 0.026 & -11.93 & $\mathrm{O}$ & 0.10 & 0.064 \\
\hline & Linear Model & 0.003 & -9.59 & 2.34 & 0.01 & 0.197 \\
\hline \multirow{2}{*}{$\begin{array}{l}\text { Early Successional } \\
\left(\text { species } / 200 \mathrm{~m}^{2}\right)\end{array}$} & Linear Model & 0.008 & -0.85 & O & 0.09 & $0.022 *$ \\
\hline & Breakpoint & 0.036 & 3.86 & 3.01 & 0.07 & 0.605 \\
\hline \multirow{2}{*}{$\begin{array}{l}\text { Mid Successional } \\
\left.\text { species } / 200 \mathrm{~m}^{2}\right)\end{array}$} & Linear Model & 0.004 & -13.70 & $\mathrm{O}$ & 0.05 & 0.116 \\
\hline & Breakpoint & 0.013 & -11.96 & 2.38 & 0.03 & 0.115 \\
\hline \multirow{2}{*}{$\begin{array}{l}\text { Late Successional } \\
(\text { species/200m²) }\end{array}$} & Linear Model & 0.000 & -113.24 & o & 0.01 & 0.533 \\
\hline & Breakpoint & 0.003 & -111.27 & 0.45 & 0.01 & 0.270 \\
\hline
\end{tabular}

\subsubsection{Changes in Forest Floor Dynamics and Microclimate}

Along the forest chronosequence, total percentage leaf litter cover ranged from 1 to $50 \%$ (Figure 9a). Leaf litter cover significantly increased with age $(\mathrm{p}<0.01$, Table 10$)$ in the linear model and reached a breakpoint of about 30\% cover after 20 years of forest development. Herbaceous cover decreased significantly with age ( $\mathrm{p}<0.0001)$, dropping to a breakpoint of $2 \%$ cover after 34 years of forest development (Figure 9b). Herbaceous cover increased again at the oldest site over time to reach $25 \%$ cover, likely due to replacement of light-demanding exotic weeds (e.g. grasses) with shade tolerant native fern regeneration (per. observation) after declines in light transmittance. Common exotic species observed within the herbaceous ground cover at the younger sites included Hedera helix, Dryopteris affinis, Clematis vitalba and grasses (not identified). Native herbaceous plants included those from the genera Asplenium, Blechnum, Polystichum, Pteridium, Pyrrosia, Histiopteris and Hypolepis.

Average daily range for air and soil temperature ranged from $3-10^{\circ} \mathrm{C}$ and $0.4-1.8^{\circ} \mathrm{C}$ respectively (Figure 9c, Figure 9d). Average daily range of soil temperature decreased significantly with age $(\mathrm{p}<0.05)$, and there was not a significant relationship between forest age and air temperature range. Daily range in soil temperature decreased most rapidly during the first 10 years. 
(a)

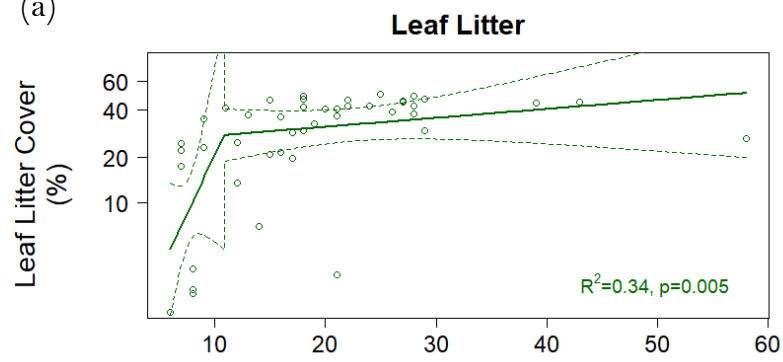

(c)

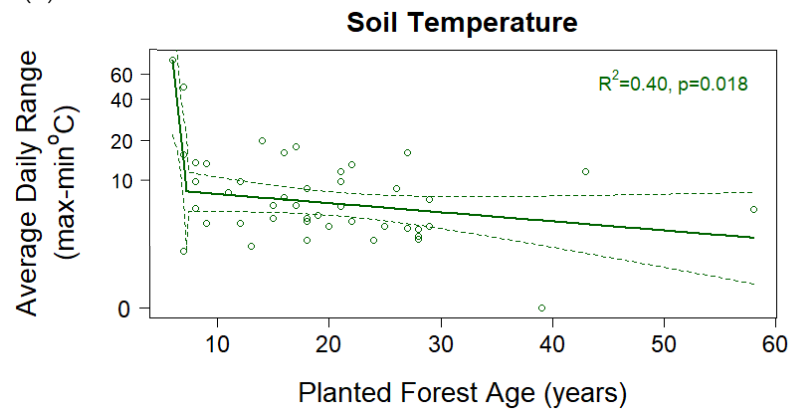

(b)

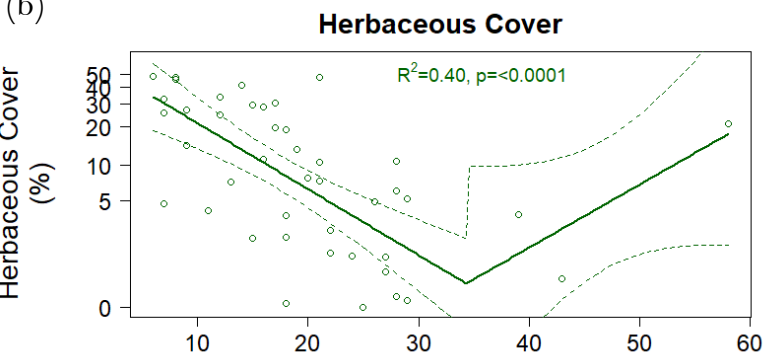

(d)

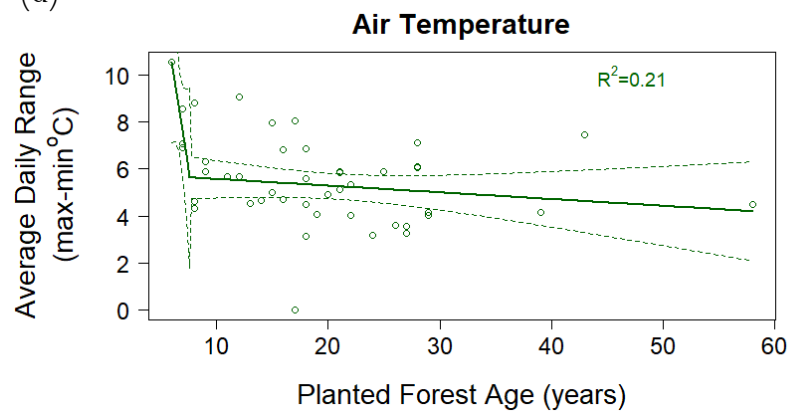

Figure 9: Linear regression models for changes in forest floor dynamics and microclimate across a planted forest chronosequence. Changes in the forest floor dynamics and microclimate over time. Plots show changes in total cover of a) leaflitter and b) herbaceous plants, and daily average range in c) soil temperature at 10cm depth, and d) air temperature at $1 \mathrm{~m}$ above ground level. Leaf litter and herbaceous cover were log transformed. All models were significant except air temperature.

Table 10: Regression analysis of the effect of forest age on forest floor dynamics and microclimate. Models with the lower AIC are displayed in the results section above. The p-value and beta estimates for the breakpoint analysis represents the significance of the first slope in the model. The second slope in all breakpoint models were not significant. In all cases $n=44$. Significance codes: $*=p<0.05, * *=p<0.01, * * * *=p<0.001, * * * *=p<0.0001$.

\begin{tabular}{|c|c|c|c|c|c|c|}
\hline Response Variable & $\begin{array}{l}\text { Statistical } \\
\text { Analysis }\end{array}$ & $\begin{array}{r}\text { Beta } \\
\text { Estimate }\end{array}$ & AIC & $\Delta$ AIC & Adjusted R ${ }^{2}$ & P-value \\
\hline \multirow{2}{*}{$\begin{array}{l}\text { Leaf Litter Cover } \\
(\%)\end{array}$} & Breakpoint & 0.137 & 22.74 & O & 0.34 & $0.005^{* *}$ \\
\hline & Linear Model & 0.015 & 30.45 & 7.71 & 0.18 & $0.002 * * *$ \\
\hline \multirow{2}{*}{$\begin{array}{l}\text { Herbaceous Cover } \\
(\%)\end{array}$} & Breakpoint & -0.094 & 51.67 & o & 0.40 & 3.e-06***** \\
\hline & Linear Model & -0.023 & 63.17 & 11.5 & 0.19 & $0.001 * * *$ \\
\hline \multirow{2}{*}{$\begin{array}{l}\text { Daily Soil } \\
\text { Temperature Range } \\
\left({ }^{\circ} \mathrm{C}\right)\end{array}$} & Breakpoint & -0.740 & 13.24 & o & 0.28 & 0.018 \\
\hline & Linear Model & -0.010 & 20.98 & 7.74 & 0.10 & $0.016^{*}$ \\
\hline \multirow{2}{*}{$\begin{array}{l}\text { Daily Air } \\
\text { Temperature Range } \\
\left({ }^{\circ} \mathrm{C}\right)\end{array}$} & Breakpoint & -3.005 & 177 & 0 & 0.21 & 0.130 \\
\hline & Linear Model & -0.057 & 183 & 1.47 & 0.07 & $0.038^{*}$ \\
\hline
\end{tabular}




\subsection{Discussion}

\subsubsection{Ecological Restoration of Urban Forests}

The linear regression models and breakpoint analyses allowed for quantitative observation of urban forest canopy development over 59 years of forest growth after planting. The results indicate that the first $10-20$ years of forest development is a dynamic period where changes are happening rapidly to the various elements representing forest community, function and stability (Table 1). After 20 years of forest growth increases in stem abundance, species richness and species richness of various plant trait guilds stabilises. There are also negative relationships with age, with sharp declines in light transmittance, herbaceous cover and temperature fluctuations. These changes suggest the sites are on a fairly good ecological trajectory, but full restoration will take time, likely requiring many more decades of development. There are actions to hasten progress towards desired ecological form, function and stability of these restored forest communities.

The significant relationships found between canopy variables and forest planting age explained between $10-80 \%$ of the range from the data mean. This indicates that while forest age is a key driver of canopy dynamics, in some cases, it is not the only factor, as, depending on the response variable of interest up to $90 \%$ of the range is sometimes unrelated to forest age. Other factors which could be influencing canopy changes include initial and enrichment planting strategies (Aerts \& Honnay, 2011), landscape integration (Rastandeh, 2018), resource availability (Tao et al., 2016) and site-level and broader scale climate conditions (Bose et al., 2017).

\section{Composition ES Structural Complexity}

These study sites are in early stages of succession, and should therefore be expected to have canopies short in stature, low basal area, high stem densities and an initially high light transmittance (Denslow \& Guzman G, 2000). In this study, stem abundance, species richness, basal area and canopy height all increased most significantly during the first 15 years of forest development concurrently with a decrease in light transmittance. In comparison mature New Zealand forests have high basal area $\left(38-75 \mathrm{~m}^{2}\right.$ ha $\left.{ }^{-1}\right)$, low stem densities (8-23 stems per $200 \mathrm{~m}^{2}$ ) and low light transmittance (1-6\%) (Bellingham et al., 1999; McDonald \& Norton, 1992).

In New Zealand forests, species richness and diversity increase with increasing stem density and basal area (Bellingham et al., 1999). Restored urban forests would benefit from plantings containing higher initial species richness and enrichment plantings to improve structural 
complexity and forest diversity. Related research in urban forest restoration indicates that species richness and plant densities (e.g. here reported as 'plant abundance') much higher than what was recorded in this study, are typical for early successional forests. A study of urban woodlands in Southern Scandinavia by Richnau et al. (2012) demonstrated that to achieve multi-tiered canopies within 25 years after planting it was necessary to establish between 1016 species initially and implement periodic thinning. The majority of our study sites had between 7-12 species, which suggests a depauperate assemblage and requirements for additional planting efforts. A study in tropical and subtropical forests of Eastern Australia by Kanowski et al. (2003) surveyed forest restoration plantings between 6-22 years old to assess structural attributes. Sites with 20-100 tree and shrub species at a density of 120 per $200 \mathrm{~m}^{2}$ resulted in high structural complexity. Plots in our study had between $20-100$ stems per $200 \mathrm{~m}^{2}$. Palik and Pregitzer (1993) describe how low density restoration plantings in forests of Northern Michigan, created large spacings between individuals of different tolerances, generating no competition for resources, and eventual development into an even-aged or single tier stand.

As expected, basal area and canopy height had similarly-shaped relationships with age. Average canopy height reached $9 \mathrm{~m}$ around 15 years post-planting and basal area reached about $35 \mathrm{~m}^{2}$ $\mathrm{ha}^{-1}$ at the same time. After this point, several forests managed to reach a basal area between $50-70 \mathrm{~m}^{2}$ ha ${ }^{-1}$. A study by Gilman et al. (2016) of planted plots in Costa Rica, showed high diversity plantings that employ niche partitioning among species could obtain a basal area of between 5-10 $\mathrm{m}^{2}$ ha ${ }^{-1}$ after 5 years of growth. Many of the forests in our study exceeded this figure after 5 years of forest growth, therefore suggesting they are developing expected levels of forest biomass. However, to improve forest biomass further, enrichment planting of tree and shrub species would support canopy strata and also improve the diversity of the understory vegetation community. Mixed forest communities produce higher biomass than monoculture or low-richness stands, especially when the component species occupy different strata and there is healthy understory regeneration and species diversity (Lusk \& Ortega, 2003). Basal area and canopy height are structural elements that are known predictors of successional changes in species and functional diversity (Lohbeck et al., 2012). They both influence forest structure and growth and are indicators of forest biomass, site quality, species diversity, and several other ecosystem functions (Tao et al., 2016).

Light transmittance decreased over the same period as increases in basal area and canopy height occurred, but while both canopy height and basal area plateaued, light transmittance continued to fall for another 10 years. This is likely due to tree canopy crowns continuing to 
widen and became multi-layered during this timeframe. In a study by Kanowski et al. (2003), tropical restoration plantings between 6-22 years old, were found to have light transmittance of (20-25\%), in comparison to primary forests (40-60 years) which had an average light transmittance of $15 \%$ and reference rainforest sites with 5-7\% light transmittance. If comparing results to Kanowski et al. (2003), it appears the level of canopy closure achieved across the present study is within an expected range and is likely to support natural regeneration of species, especially specialist late successional plants that are more shade-tolerant. Light is a key resource for plant growth and stratified canopies create successive light interception levels from canopy to forest floor (Sercu et al., 2017). Over successional time, tree architecture will change to suite exogenous conditions, and architectural traits such as plant height will selfregulate to intercept available light resources (Falster \& Westoby, 2005). Tree species also differ in the quantity and heterogeneity of light they transmit due to differing morphological traits. Therefore, it is most beneficial for initial and enrichment plantings to include a wide variety of canopy and subcanopy species to create higher overstory diversity and increase stratification, which will encourage spatial heterogeneity of light transmittance throughout the understory leading to a higher diversity of available regeneration niches.

Most reforestation approaches focus on tree succession, not whole system succession (Duryea et al., 2000) and the herbaceous layer is an often underappreciated aspect of forest ecosystems. The suppression of exotic herbaceous species and restoration of a native herbaceous layer is necessary to achieve a truly diversified forest community with multi-layered vegetation strata. The ground herbaceous layer affects the success of all forest plants, including the regeneration of dominant canopy trees (Gilliam, 2007). Herbaceous cover across sites in this study had a significant relationship with age and declined with a decrease in light transmittance. Herbaceous cover decreased from $100 \%$ to less than $5 \%$ within the first 25 years and then increased again in the 3 oldest sites, along with a minor increase in light transmittance. The increase in herbaceous cover towards the later stages is likely due to an increase in the arrival of native herbaceous species, although our surveys did not delineate between native and exotic herbaceous cover.

Surprisingly, canopy diversity did not have any relationship with planting age at all, with most sites, including both the youngest and oldest, sitting between a Shannon's Diversity Index of 1-2. This result differs from studies of other natural and restored forest ecosystems, which generally increase in diversity with forest age or succession (Bazzaz, 1975; Garcia et al., 2016; Gilman et al., 2016). Diversity of naturally occurring evergreen broadleaf forest canopies studied by Hagihara et al. (2008) on Okinawa Island in Japan, showed much higher woody 
species diversity, indicating this is possible in forests, but pointedly, for those with multiple canopy tiers. Canopies were structurally stratified and split into four layers, with Shannon's diversity ranging from the canopy tier to ground level tier being $2.75,4.37,4.73$ and 4.33 respectively. The oldest site within the present study had a diversity index of 1.8 which is much lower than all tiers assessed by Hagihara et al. (2008) and the most diverse site of our study also fell short at 2.5. Because diversity in the forests measured for this study did not increase with time, this could be a function of the planting strategies initially used. An increase in planting density, species richness, canopy stratification and enrichment planting efforts will improve structural complexity which will in term improve forest diversity and ecological integrity. Other restoration management strategies also exist, such as the establishment of species with specifically chosen traits. This engineering approach creates a variety of physiological or morphological differences that leads to improved ecological function and interactions such as competition, creating diverse plant growth rates, particularly in the sapling stage (Palik \& Pregitzer, 1993).

\section{Ecological Function}

Similar to another study of natural forest succession in New Zealand (Mark et al., 1964) we found changes to forest composition and structure occurred over the same time frame as a significant drop in daily microclimate extremes. Range in daily temperature decreased sooner for soil than for air, with soil temperature stabilising by $0.8^{\circ} \mathrm{C}$ within 10 years and air by $2.5^{\circ} \mathrm{C}$ within 15 years. Results here show dampening of fluctuations in microclimate in the first 20 years at the same time as a decrease in herbaceous cover to less than $10 \%$ and an increase in leaf litter ground cover to $30 \%$. These factors create a microclimate suitable for seedling germination and growth (Von Arx et al., 2012) and the dampening of temperature fluctuations is a positive result which may indicate that natural ecological processes and functional relationships are on track in these restored forests. However, a search of the literature found no studies that looked at changes in microclimate range with successional time or along planting chronosequences. So, we are unable to state whether these temperature drops are comparable to natural forest systems or other restoration studies.

Leaf litter accumulation is associated with forest age and changes in canopy structure and composition. Leaf litter cover reaches about $30 \%$ after 20 years of forest development, by which point canopy basal area, height, stem abundance and species richness had already reached a point of equilibrium, with temporal changes plateauing about 5-10 years prior. Litterfall reflects forest productivity and is an important pathway of nutrient cycling in forests (Allen et 
al., 2013a). Facelli and Pickett (1991) suggest that a rapid accumulation of litter occurs during the very early stages of succession, followed by a temporary equilibrium during the midsuccessional stage, and a second phase of accumulation when trees displaces dominant herbs. We found a similar pattern of leaf litter accumulation within the early stages of forest growth, with leaf litter cover rapidly reaching an average of $30 \%$ after 20 years and then plateauing after this period. At this point canopy basal area, height, stem abundance and species richness had also reached a point of equilibrium, with temporal changes plateauing about 5-10 years prior.

Little attention is given toward building healthy understory strata and international studies suggest these often provide more than $80 \%$ of a forest's diversity (Gilliam, 2007; McClain et al., 2011) leading to its large role in restoring ecosystem function. No studies looking at understory diversity levels were found in New Zealand to aid comparison. In order to fasttrack an urban forest towards a comparable state, the establishment of a high richness of species traits best suited to current site conditions is required (Garcia et al., 2016). For example, a meta-analysis by Gómez-Aparicio et al. (2004) compared the survival and growth of tree seedlings planted in open areas with seedlings planted under the canopy of pre-existing shrub species. They showed that pioneer shrubs facilitate the establishment of woody, latesuccessional species in a variety of ecological settings tested (both wet and dry ecological zones). However, another study by Duncan and Chapman (2003) on forest succession in Uganda demonstrated that the outcome of shrub - tree interactions depended on species-level traits. The present study's sites had very few shrubs with only five sites having 1-2 shrub species recorded, and all of these sites were over 10 years old. The presence of the few shrub species found may be due to either natural arrival or enrichment planting activities. No sites under 10 years of age had any shrubs present, which is a time they would naturally be more common. It would be beneficial if restoration programmes placed additional emphasis on the inclusion of light and shade-loving shrubs in initial and enrichment planting efforts alongside trees.

Dominant successional traits found within the restored canopies were those of species that could be planted in early-successional environments. The richness of early successional species was about five times higher than mid-successional species, and overall species richness of pioneers sat in the middle. This pattern echoes studies of naturally regenerating secondary forest sites which have greater early successional species richness with a few light-demanding pioneer species (van Breugel et al., 2007). However, here difference in trait densities was not assessed, and it is important to note that pioneer species usually exist in much higher densities 
in secondary and early successional forests than do other successional species, with densities starting to decline only as canopy closure occurs. Only 38\% of this study's sites contained any pioneer species (most commonly Cordyline australis or Kunzea ericoides) and this was a lower proportion than expected. Conditions across the sites are likely not yet appropriate for latesuccessional species to survive, even if they had been planted, and capacity for dispersal is likely to be low due to lack of seed source availability. This is supported by the fact only two sites had late-successional canopy species. Planting of late successional species (i.e. enrichment planting) can be undertaken during enrichment planting stages, but it should be done so strategically, with prevailing conditions being well considered, such as wind protection, light levels, soil health and on-going site or plant maintenance. For example, Tulod et al. (2019) showed that plantings of Totara (Podocarpus totara) survived well in plantings of Kunzea ericoides if light wells were created, allowing Totara to grow consistently taller under these conditions. They also demonstrated that Totara growth and survival was variable when planted within exposed edge habitats.

Results from this chapter indicate that the first 15 years of planted forest development exhibit major changes in canopy composition, forest structure and microclimate stabilisation. This period saw significant increases in canopy abundance, height and basal area and declines in light transmittance and daily temperature range. Dominant species traits within the restored canopies were fairly representative of what is usually found within restored or remnant forests at similar early stages of ecosystem development. Restored forest canopies were dominated by early successional and pioneer species and small to medium-sized tree species. There were few late successional species found which is to be expected in forests so young, however enrichment planting of these could enable colonization of late successional species sooner. 


\subsection{Introduction}

The regeneration of a diverse population of seedling species largely determines what species will successfully establish in a matured forest community (Bose et al., 2016). However, in restored urban forests, the natural regeneration of seedlings, a key process in forest development (Arroyo-Rodriguez et al., 2017; Proença et al., 2012), is severely hampered. This lack of seedling regeneration is creating a significant barrier to the complete ecological recovery of restored urban forest ecosystems (Wallace et al. 2017).

Some strategies for forest restoration to promote seedling regeneration include planting a diversity of woody species, structural classes, traits, tolerances and consideration of species' ecological requirements and niches (Asanok et al., 2013; Bose et al., 2016; Catovsky \& Bazzaz, 2002; Holl et al., 2013). Many publications provide recommendations which include strategies listed above; as well as spatial arrangements such as random placement (but in ideal conditions), non-linear plantings, small areas of high density and high richness plantings (planting nodes) and multiple grouping of same-species (Charles et al., 2018; Marchetto et al., 2010; Zahawi \& Augspurger, 2006). Adaptive management activities known to assist natural regeneration within planted urban forests include the removal of exotic shade-tolerant species (Elgar et al., 2014), enrichment plantings of a diverse range of native plant groups (ferns, grasses, herbs, shrubs, climbers etc) (Lamb et al., 2005) and traits (leaf size, plant heights, dispersal and pollinator mechanisms) (Carreiro et al., 2008), periodic thinning to create light wells and habitat niches (Gray \& Spies, 1997), and planting of 'habitat corridors' to link surrounding natural landscapes (Meurk \& Swaffield, 2000).

Despite this abundance of theoretical information for shaping initial and adaptive planting strategies, it is poorly implemented in restoration practice, resulting in urban forests without capacity to self-regenerate over the long term. This is largely due to a lack of ecological complexity, processes, functions and especially habitat niches within the restored ecosystem that allow for diverse natural regeneration. Rarely do restoration programmes take a bigpicture approach (Stanturf et al., 2012), where several or all strategies are implemented to restore urban forests at an ecosystem level. For example, restoration sites often have only trees planted, in unnatural, equally spaced rows, with very low densities and species richness levels, 
a single canopy tier and an understory deplete of any other native plant groups except trees (Aerts \& Honnay, 2011; Gilliam, 2007; Mansourian et al., 2005; Norton et al., 2018).

Contemporary studies of seedling regeneration constraints within forest plantings can sometimes exacerbate this tendency to look narrowly at what is needing to be restored, by assessing only one or two processes, interactions or relationships occurring at a single point in time. Research of temporal trends and dominant drivers of forest development across decadal timescales requires an all-encompassing perspective on the patterns occurring within the seedling community and existing barriers for urban forests to self-regenerate. Studies also rarely examine the combined roles of canopy composition, environmental conditions and landscape context on seedling regeneration, all of which play an important role in determining seedling regeneration dynamics (Vayreda et al., 2013). Effective restoration requires a multifaceted approach, where all potential components, processes and inhabitants of the restored system are considered in both the initial and adaptive management stages.

Seedling regeneration is often used as an indicator of restoration success, allowing for consideration of whether past and current planting strategies (such as tree density and richness) are leading to the establishment of a self-sustaining natural forest community. But the natural regeneration of seedlings is a complex process due to interactions with a broad range of abiotic and biotic factors that hinder natural regeneration at every stage of urban forest development (Kozlowski, 2002) and must be managed accordingly.

\subsubsection{Objective}

The objective of this study is to 1) investigate temporal trends occurring within the restored urban forest seedling community and 2) identify key drivers of seedling diversity. This analysis provides an indication of how choices made in early planting stages and subsequent trajectory of a restoration project influences seedling regeneration. The present study shows how important it is to consider multiple abiotic and biotic factors at the species, site and landscape levels for the achievement of the critical process of seedling regeneration.

\subsection{Methods}

For a description of general methodologies regarding research plot set up, data collection and research variables, please refer to Chapter 1 of this thesis. Presented here are the methods used specifically for data analysis to answer questions surrounding temporal trends in this chapter. 


\subsubsection{Data Analysis}

The independent variable of interest for the analysis of temporal trends is planted forest age (years since planting). Response variables representing seedling community dynamics included: stem abundance, species richness, diversity, structural classes, successional stage traits, drought and shade tolerance, pollinator traits, dispersal mechanisms and reproductive traits.

The independent variables of interest for the analysis of dominant drivers were split into two groups: abiotic and biotic drivers. Independent variables representing abiotic drivers included: soil temperature, air temperature, light transmittance, site history, annual sunshine hours and annual rainfall. Independent variables representing changes in a restoration sites' biotic drivers included canopy diversity, sapling diversity, leaf litter cover, herbaceous cover, basal area, canopy height and natural landcover. The response variable was seedling diversity.

\section{$\underline{\text { Linear Regression }}$}

Linear regression models $(\mathrm{LM})$ were used to test the effect of forest planting age on the ten response variables listed above. All response variable data were transformed using a $\log 10$ transformation due to non-normal data distribution which corrected the issue of non-normality in all instances. Probability values ( $\mathrm{p}$-value), adjusted $\mathrm{R}$-squared (adj. $\mathrm{R}^{2}$ ) and akaike information criterion (AIC) were retrieved from the fitted linear regression models. These statistics were used to assess how well the model fitted the data, whether it was statistically significant and to compare the quality of the linear model to the alternative model including breakpoints. If linear regression models were the preferred model (lower AIC), these were chosen to display graphically in the results section. 95\% confidence intervals were plotted on graphs only if the $\mathrm{R}^{2}$ value was equal to or over 0.20 and $\mathrm{p}$-values were added to graphs only if they were significant $(\mathrm{p}<0.05)$.

\section{Breakpoint Analysis}

Breakpoint analysis was used to look for possible thresholds in seedling regeneration. Once a linear regression model was fitted, a second model was fitted using the 'segmented' package (Ostertag et al., 2015). The segmented package allows for the assessment of breakpoints within a LM. A segmented relationship is defined by the slope parameters and the breakpoint(s) where the linear slope changes significantly relative to the next segment in the line. Statistical analysis allowed the $\mathrm{R}$ code run to self-select the number of breakpoints present within the model and outputs always resulted in only 1 significant breakpoint. Breakpoint models are displayed 
graphically in the results section if they had a lower AIC value than the normal, initially produced LM for the same variables. Confidence intervals where plotted with breakpoint regression lines if the adj. $\mathrm{R}^{2}$ value was equal to or over 0.20 . Adj. $\mathrm{R}^{2}$ values less than 0.20 were considered not to represent the data well.

\section{Linear Mixed-Effects Models}

Predictors of seedling diversity were assessed using linear mixed effects modelling. Three models of predictor-response relationships were produced using the 'lme-4' package (Bates, 2007) which fits a linear mixed-effects model (LMM) to data, via maximum likelihood (ML). Due to the comparisons of AIC, ML was used. Two-way ANOVA tests were done to view the significance of each term in the model, then coefficients were plotted using package 'coefplot' (Lander, 2018). The mixed effect plots show point estimates and 95\% confidence intervals for fitted models. All predictors tested were transformed using a $\log 10$ transformation due to nonnormal data distribution. The first model included abiotic predictors such as air and soil temperature, light transmittance, site history and regional climate data. The second model tested only biotic predictors and included sapling and canopy diversity, basal area, canopy height, herbaceous and leaf litter cover and the proportion of natural landcover. These models were used to identify significant abiotic and biotic predictors which were added into the final model of dominant drivers.

\section{Nonmetric Multidimensional Scaling}

To examine species similarity among plots, Bray-Curtis similarity scores were calculated for seedling communities. Kruskals nonmetric multidimensional scaling (NMDS) was used to represent community variation between study sites. NMDS uses information on the abundance of each species to examine community similarity in two dimensional composite variable space (Clarke \& Warwick 2001). Species' abundance was input as the untransformed number of seedlings sampled per plot (seedling community). The analysis was performed using both 'Vegan' and 'labdsv' packages (Oksanen et al, 2013; Roberts, 2019) within R statistical software ( $\mathrm{R}$ Core Team, 2013). The age since planting and city of each site were visualised using coloured labels and point symbols, respectively, in the two dimensional NMDS plots.

\subsection{Results}

We recorded a total of 140 species of seedlings including exotics and natives from 61 plant families within the 44 study plots. Out of those, native seedlings represented 45 plant families 
and 123 species. Seedlings from the Coprosma genus were the most dominant group, present at every site with 4,845 individuals recorded in total, including 13 species and two common hybrids. Seven tree species were present in at least $50 \%$ of the sites, reported here in decreasing order from the most widespread across sites: Pittosporum tenuifolium, Pittosporum eugenioides, Griselinia littoralis, Cordyline australis, Melicytus ramiflorus, Muehlenbeckia australis and Podocarpus totara var. totara. An additional 16 species were regenerating at over $25 \%$ of the sites and there were 40 seedling species which were fairly uncommon and represented in only $5 \%$ of the sites or less (see Appendix 2).

We identified 37 exotic species of seedlings from 24 plant families, and total count was 3,332 individuals, representing $16.83 \%$ of the total count of seedlings recorded across all sites ( $\mathrm{n}=19,796)$. The most widespread exotic species were Rubus fruticosus agg (54\% of the sites), Hedera helix (47\%), Berberis darwinii (31\%), Ulex europaeus (27\%), Prunus avium (24\%) and Clematis vitalba (15\%).

Wellington plots had the highest number of native seedling families and species richness but had one of the two lowest overall seedling counts (Table 11). Dunedin had the lowest number of seedling families along with Nelson, as well as the lowest seedling species richness and count. Christchurch had the highest total count and species richness of liane seedlings and second highest species richness and count of shrubs seedlings. Wellington had the highest abundance of ferns followed by Invercargill. Invercargill had the highest count of shrubs, but Christchurch had the highest species richness. Nelson had the lowest count and species richness of lianes and the lowest count of ferns.

Table 11: Summary of seedling regeneration by city. Displayed is the total richness (Rich.) and count (Cnt.) of seedling groups recorded from each of the 9 sites across each city (except Dunedin which had 8 sites).

\begin{tabular}{|c|c|c|c|c|c|c|c|c|c|c|c|}
\hline \multirow[t]{2}{*}{ City } & \multirow{2}{*}{$\begin{array}{r}\text { № of } \\
\text { Families }\end{array}$} & \multicolumn{2}{|c|}{ № of Species } & \multicolumn{2}{|c|}{ № of Trees } & \multicolumn{2}{|c|}{ № of Shrubs } & \multicolumn{2}{|c|}{ № of Ferns } & \multicolumn{2}{|c|}{ № of Lianes } \\
\hline & & Rich. & Cnt. & Rich. & Cnt. & Rich. & Cnt. & Rich. & Cnt. & Rich. & Cnt. \\
\hline Wellington & 36 & 56 & 2697 & 39 & 2320 & 6 & 96 & 8 & 158 & 3 & 123 \\
\hline Nelson & 21 & 43 & 3821 & 29 & 3564 & 8 & 146 & 4 & 20 & 2 & 91 \\
\hline Dunedin & 21 & 38 & 1933 & 24 & 1353 & 5 & 133 & 6 & 129 & 3 & 318 \\
\hline Christchurch & 25 & 51 & 3581 & 30 & 2387 & 12 & 197 & 3 & 41 & 6 & 956 \\
\hline Invercargill & 23 & 42 & 7052 & 21 & 5283 & 9 & 1412 & 8 & 135 & 3 & 222 \\
\hline
\end{tabular}

The seedling species that were most wide-spread across sites differed from those with the highest average abundance when present (Figure 10, Appendix 2). Species with the highest average abundance when present at a site include: Streblus heterophyllus, Piper excelsum subsp. 
excelsum, Passiflora tetrandra, Melicytus ramiflorus subsp. ramiflorus, Dodonaea viscosa, Parsonsia heterophylla, Pseudopanax laetus and Hoheria angustifolia. All these species were in less than 12 plots, except for Melicytus ramiflorus subsp. ramiflorus which was present in 24 plots.

\section{Seedling presence across sites vs. average abundance when present}

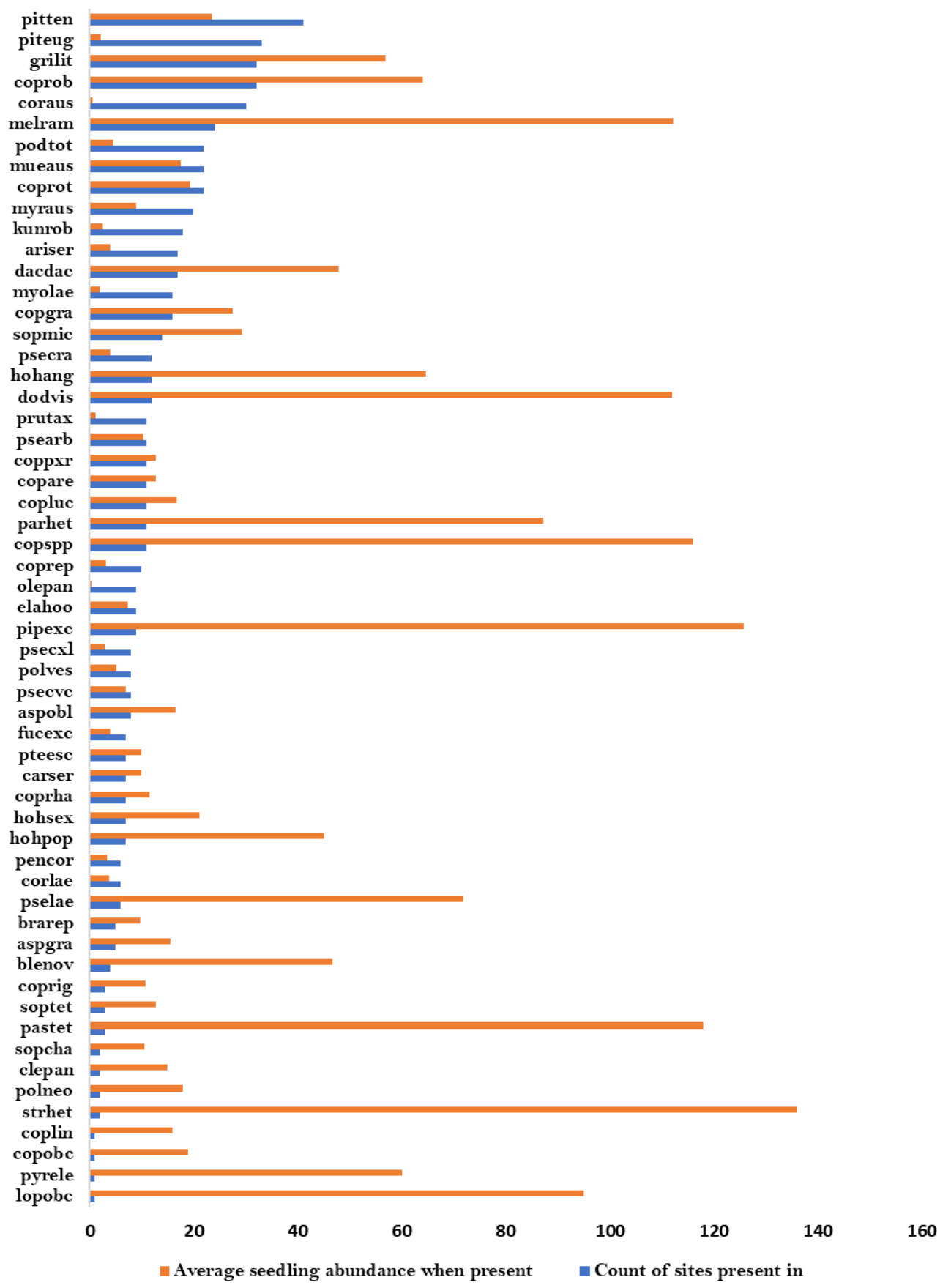

Figure 10: Presence of native seedling species across study sites and the average abundance (average number of individuals) of each species when present in a plot. Species chosen to display in graph which were either a) the most wide-spread with a minimum presence across 5 sites or b) the highest average abundance with a minimum 
abundance of 20. Average abundance was calculated by dividing the number of sites a species was present in, by the total count recorded. A key to species codes can be found in Appendix 2.

The results of the NMDS suggest that the assemblage of seedling communities (plants $<1.5 \mathrm{~m}$ high and $<2.5 \mathrm{~cm} \mathrm{DBH}$ ) where dependant on the city within which they were present more so than the age of the restoration planting (Figure 11). The NMDS plot shows a slight clustering of cities (Figure 11). In particular, Invercargill City had the strongest cluster, followed by Dunedin which had a similar community composition along the NMDS 2 axis. The cities of Christchurch, Nelson and Wellington had a more spread distribution of seedling community composition. However, it should be noted that the stress value of $2.5 \%$ is just outside the recommended range (Clarke \& Warwick 2001), hence the representation of points in the plot should not be entirely relied on. Two sites from Invercargill (EstWk and ThoBE) had zero seedlings in the seedling plots and appear as overlapping outliers to the bottom-right of the NMDS plot.

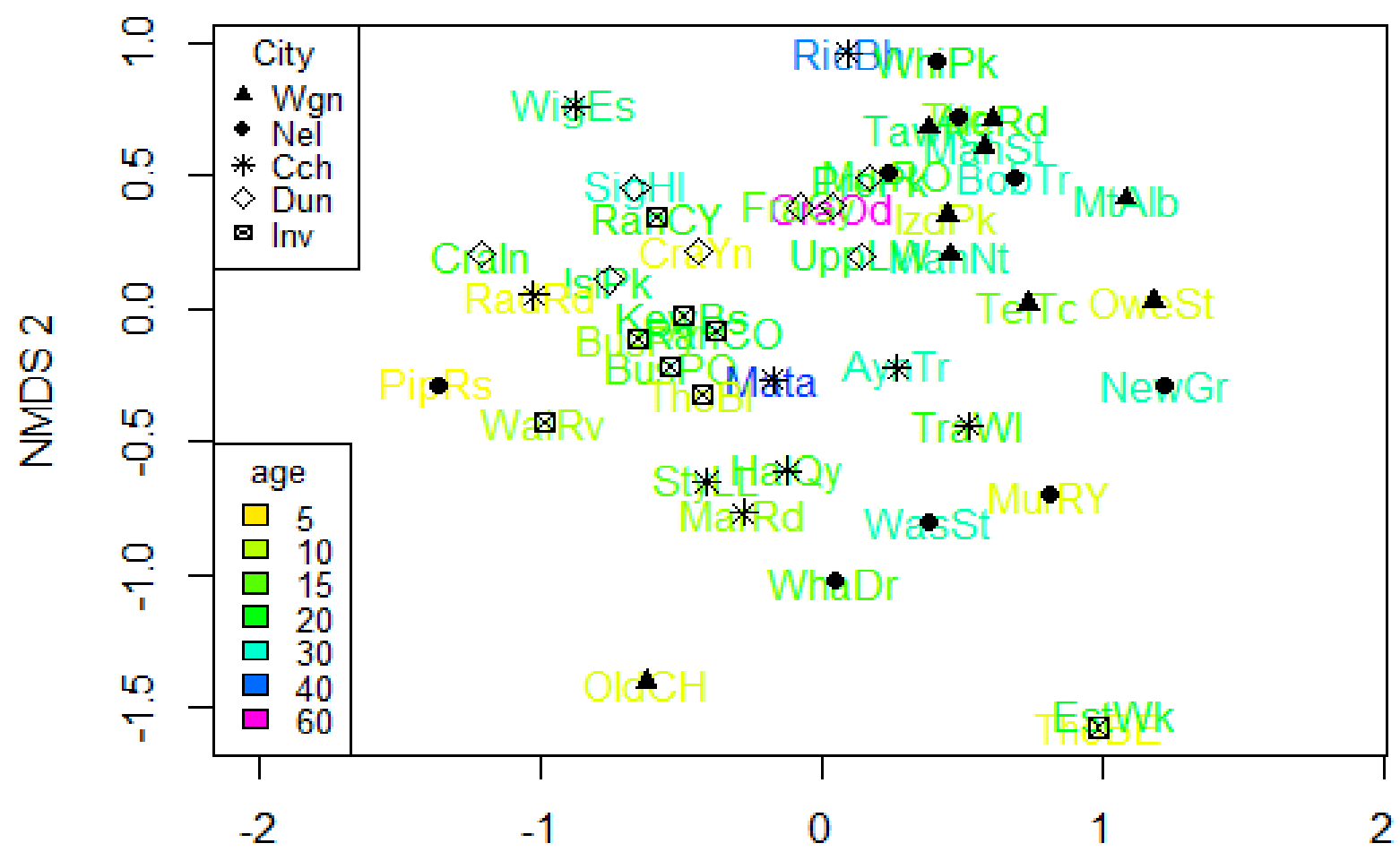

\section{NMDS 1}

Figure 11: A two-dimensional NMDS ordination of the similarities in seedling community composition across five cities and a forest age chronosequence based on Bray-Curtis similarities (stress $=0.25)$. City codes are: Wellington (Wgn), Nelson (Nel), Christchurch Cch), Dunedin (Dun) and Invercargill (Inv). 
Seedling abundance ranged from 0 to 3,890 seedlings per plot (the total area of all seedling quadrats which is $70 \mathrm{~m}^{2}$ ) (Figure 12a). Five sites exceeded a total of 1,000 seedlings, and fifteen had under 100 individuals. Seedling abundance increased significantly with age $(p<0.05)$ in the linear model (Table 12:) with a breakpoint at 10 years. Seedling richness increased significantly with planting age $(\mathrm{p}<0.05)$ and ranged from 0 to 30 species per plot, but there was no breakpoint identified (Figure 12b). Seedling diversity (Figure 12c) did not show any significant relationship with planting age.

Trees were the dominant plant growth form regenerating within the seedling community followed by shrubs and epiphytes (Figure 12d). Tree fern seedlings were recorded at only two sites in Wellington. No plant growth forms increased significantly with age except lianes. The most widespread liane species were Muehlenbeckia australis at 50\% of the sites, Parsonsia heterophylla (22\%) and Passiflora tetrandra (7\%). Six epiphytic species (only those typically known as obligate hemiphytes and epiphytes were included) commonly found within the forest floor seedling community were Asplenium appendiculatum subsp. appendiculatum, Asplenium flaccidum, Pseudopanax laetus and Pyrrosia elaeagnifolia, Asplenium oblongifolium and Lomaria discolor. Ground fern species richness had no relationship with forest age. The most common ground fern species were Asplenium oblongifolium present at $18 \%$ of the sites followed by Polystichum vestitum (15\%) and Pteridium esculentum (15\%) (see Appendix 2).

Regenerating seedling communities were dominated by early and mid-successional species (Figure 12e), but only early successional species increased significantly with age $(\mathrm{p}<0.05)$ and had a breakpoint at 10 years. On average, early and mid-successional species ranged from 2 to 17 and 1 to 12 species respectively across the chronosequence. Four sites had 1-2 late successional seedling species present and three sites were over 20 years. Seedling communities were also dominated by moderately shade and drought tolerant species (Figure 12f, Figure $12 \mathrm{~g}$,) and species which produce fruits as their reproductive strategy, require insects for pollination and frugivory agents (e.g. birds) for dispersal (Figure 12h, Figure 12i, Figure 12j). 
(a)

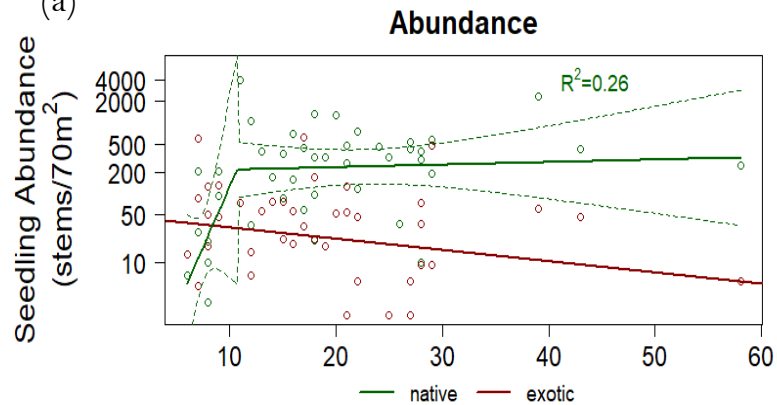

(c)

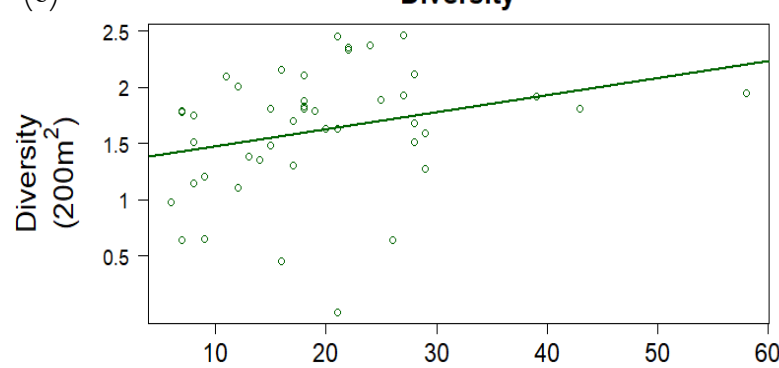

(e)

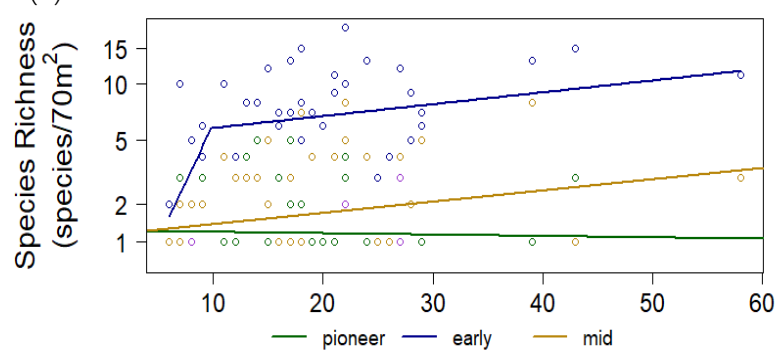

(g)

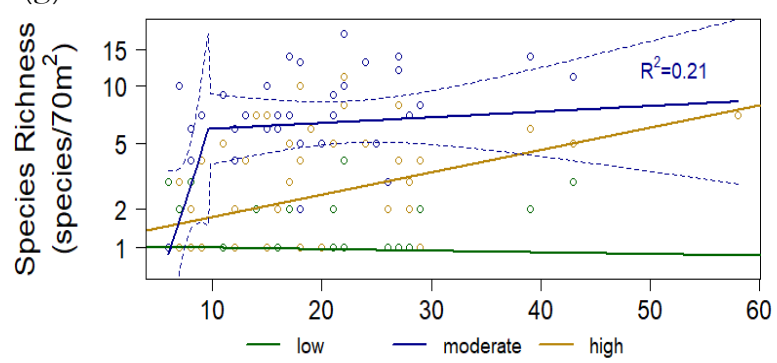

(i)

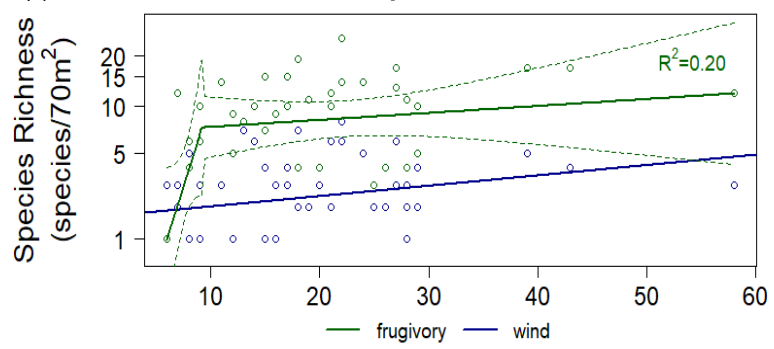

Planted Forest Age (years) (b)

Species Richness

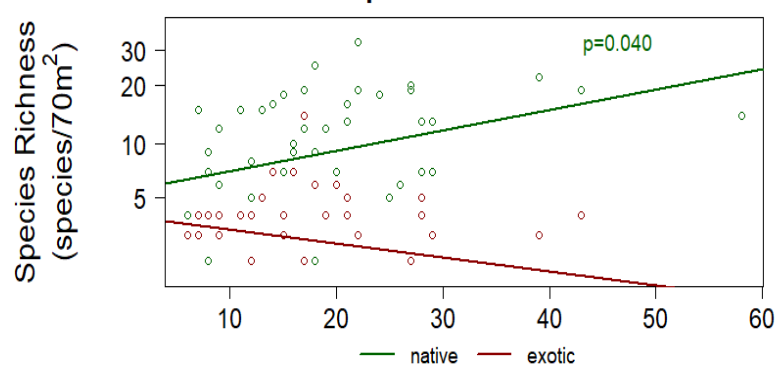

(d)

Structural Classes

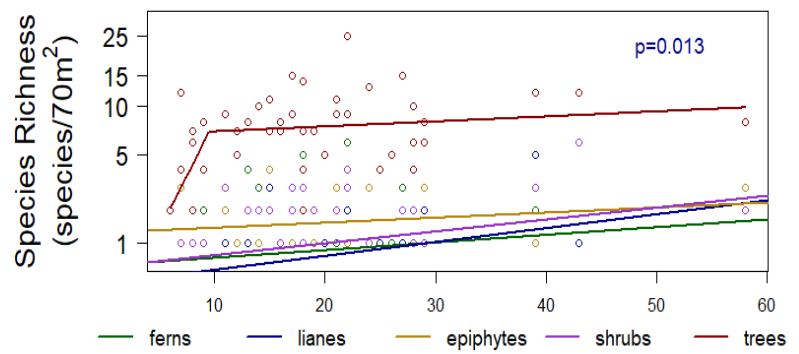

(f)

Drought Tolerance

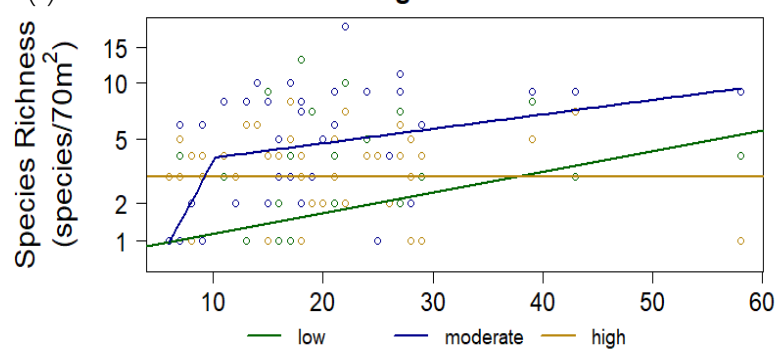

(h)

Pollinator Traits

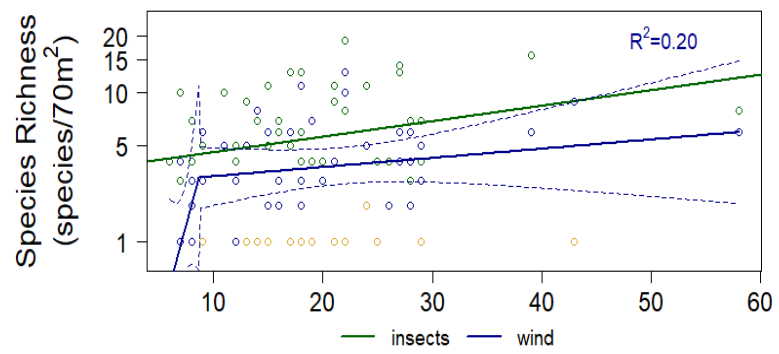

(j) Reproductive Traits

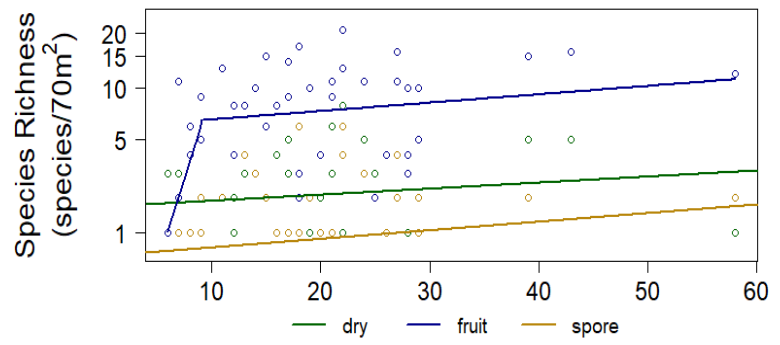

Planted Forest Age (years)

Figure 12: Linear regression models for seedling regeneration dynamics across a forest planting chronosequence.

Plots show changes in seedling a) abundance, b) species richness, c) diversity, d) structural classes, e) successional 
classes, f) drought tolerance, g) shade tolerance, h) pollinator traits, i) dispersal traits and j) reproductive traits. Yellow points within the pollinator trait plot represent bird pollinated species and low data points meant a linear model would not fit to the data. Purple points within the successional class plot represent late successional species which a linear model would not fit to due to a lack of data points. All variables were log transformed except for seedling diversity. Only significant models were overall species richness and the species richness of tree species.

Table 12: Regression analysis of the effect of forest age on seedling regeneration dynamics. The seedling trait response variable is the species richness per site $\left(\right.$ species $\left./ 70 m^{2}\right)$. Models with the lower AIC are displayed in the results section above. The p-value and beta estimates for the breakpoint analysis represents the significance of the first slope in the model. The second slope in all breakpoint models were not significant. In all cases $n=44$. Significance codes: $*=p<0.05, * *=p<0.01, * * *=p<0.001, * * * *=p<0.0001$.

\begin{tabular}{|c|c|c|c|c|c|c|}
\hline Response Variable & $\begin{array}{l}\text { Statistical } \\
\text { Analysis }\end{array}$ & $\begin{array}{r}\text { Beta } \\
\text { Estimate }\end{array}$ & AIC & $\Delta \mathrm{AIC}$ & Adjusted R ${ }^{2}$ & P-value \\
\hline \multirow{2}{*}{$\begin{array}{l}\text { Native Abundance } \\
\left(\text { stems } / 70 \mathrm{~m}^{2}\right)\end{array}$} & Breakpoint & 0.336 & 100.42 & $\mathrm{O}$ & 0.26 & 0.182 \\
\hline & Linear Model & 0.027 & 107.42 & 7.00 & 0.09 & $0.021 *$ \\
\hline \multirow{2}{*}{$\begin{array}{l}\text { Exotic Abundance } \\
\left(\text { stems } / 70 \mathrm{~m}^{2}\right)\end{array}$} & Linear Model & -0.015 & 101.43 & o & 0.02 & 0.149 \\
\hline & Breakpoint & -0.015 & 102.81 & 1.38 & 0.03 & 0.104 \\
\hline \multirow{2}{*}{$\begin{array}{l}\text { Native Richness } \\
\left.\text { (species } / 70 \mathrm{~m}^{2}\right)\end{array}$} & Linear Model & 0.009 & 27.18 & o & 0.07 & $0.040^{*}$ \\
\hline & Breakpoint & 0.117 & 27.47 & 0.29 & 0.10 & 0.274 \\
\hline \multirow{2}{*}{$\begin{array}{l}\text { Exotic Richness } \\
\left(\text { species } / 70 \mathrm{~m}^{2}\right)\end{array}$} & Linear Model & -0.006 & 9.74 & $\mathrm{O}$ & 0.04 & 0.084 \\
\hline & Breakpoint & -0.016 & 11.63 & 1.89 & 0.04 & 0.092 \\
\hline \multirow{2}{*}{$\begin{array}{l}\text { Diversity } \\
\left(70 \mathrm{~m}^{2}\right)\end{array}$} & Linear Model & 0.013 & 94.21 & $\mathrm{O}$ & 0.02 & 0.177 \\
\hline & Breakpoint & 0.034 & 96.82 & 2.61 & 0.00 & 0.928 \\
\hline \multicolumn{7}{|l|}{ Structural Classes } \\
\hline \multirow{2}{*}{$\begin{array}{l}\text { Ground Ferns } \\
\left(\text { species } / 70 \mathrm{~m}^{2}\right)\end{array}$} & Linear Model & 0.004 & 9.68 & $\mathrm{O}$ & 0.00 & 0.283 \\
\hline & Breakpoint & 0.100 & 11.08 & 1.4 & 0.01 & 0.271 \\
\hline \multirow{2}{*}{$\begin{array}{l}\text { Lianes } \\
\left(\text { species } / 70 \mathrm{~m}^{2}\right)\end{array}$} & Linear Model & 0.007 & -14.43 & $\mathrm{O}$ & 0.11 & $0.013^{*}$ \\
\hline & Breakpoint & 0.067 & -12.29 & 2.14 & 0.10 & 0.499 \\
\hline \multirow{2}{*}{$\begin{array}{l}\text { Epiphytes } \\
\left(\text { species } / 70 \mathrm{~m}^{2}\right)\end{array}$} & Linear Model & 0.002 & 6.58 & $\mathrm{O}$ & 0.04 & 0.377 \\
\hline & Breakpoint & 0.020 & 9.46 & 2.88 & 0.02 & 0.912 \\
\hline \multirow{2}{*}{$\begin{array}{l}\text { Shrubs } \\
\left(\text { species } / 70 \mathrm{~m}^{2}\right)\end{array}$} & Linear Model & 0.006 & 5.04 & $\mathrm{O}$ & 0.05 & 0.078 \\
\hline & Breakpoint & 0.006 & 7.41 & 2.37 & 0.03 & 0.640 \\
\hline \multirow{2}{*}{$\begin{array}{l}\text { Trees } \\
\left(\text { species } / 70 \mathrm{~m}^{2}\right)\end{array}$} & Breakpoint & 0.115 & 14.22 & $\mathrm{O}$ & 0.11 & 0.215 \\
\hline & Linear Model & 0.007 & 15.42 & 1.2 & 0.05 & 0.060 \\
\hline \multicolumn{7}{|l|}{ Successional Status } \\
\hline \multirow{2}{*}{$\begin{array}{l}\text { Pioneer } \\
\left(\text { species } / 70 \mathrm{~m}^{2}\right)\end{array}$} & Linear Model & -0.000 & 0.95 & $\mathrm{O}$ & -0.02 & 0.859 \\
\hline & Breakpoint & -0.034 & 2.81 & 3.58 & -0.02 & 0.474 \\
\hline \multirow{2}{*}{$\begin{array}{l}\text { Early Successional } \\
\left(\text { species } / 70 \mathrm{~m}^{2}\right)\end{array}$} & Breakpoint & 0.103 & 17.10 & o & 0.15 & 0.270 \\
\hline & Linear Model & 0.010 & 17.33 & 1.87 & 0.11 & $0.012^{*}$ \\
\hline \multirow{2}{*}{$\begin{array}{l}\text { Mid Successional } \\
\left(\text { species } / 7 \mathrm{Om}^{2}\right)\end{array}$} & Linear Model & 0.005 & 19.27 & $\mathrm{O}$ & 0.01 & 0.227 \\
\hline & Breakpoint & 0.054 & 21.02 & 2.78 & 0.01 & 0.592 \\
\hline \multirow{2}{*}{$\begin{array}{l}\text { Late Successional } \\
\left(\text { species } / 70 \mathrm{~m}^{2}\right)\end{array}$} & Linear Model & 0.000 & -51.16 & $\mathrm{O}$ & -0.01 & 0.606 \\
\hline & Breakpoint & 0.008 & -49.52 & 2.28 & -0.01 & 0.265 \\
\hline Reproductive Trait & & & & & & \\
\hline
\end{tabular}




\begin{tabular}{|c|c|c|c|c|c|c|}
\hline Fruit & Breakpoint & 0.176 & 22.07 & $\mathrm{O}$ & 0.18 & 0.086 \\
\hline$\left(\right.$ species $\left./ 70 m^{2}\right)$ & Linear Model & 0.010 & 24.75 & 2.68 & 0.09 & $0.023^{*}$ \\
\hline Dry & Linear Model & 0.003 & -4.21 & $\mathrm{O}$ & -0.00 & 0.344 \\
\hline$\left(\right.$ species $\left./ 70 m^{2}\right)$ & Breakpoint & 0.032 & -3.56 & 0.65 & 0.02 & 0.111 \\
\hline Spore & Linear Model & 0.004 & 13.90 & $\mathrm{O}$ & 0.00 & 0.277 \\
\hline$\left(\right.$ species $\left./ 70 m^{2}\right)$ & Breakpoint & 0.104 & 15.33 & 1.43 & 0.01 & 0.274 \\
\hline \multicolumn{7}{|c|}{ Dispersal Mechanism } \\
\hline \multirow{4}{*}{$\begin{array}{l}\text { Frugivory } \\
\left(\text { species } / 70 \mathrm{~m}^{2}\right) \\
\text { Wind } \\
\left(\text { species } / 70 \mathrm{~m}^{2}\right)\end{array}$} & Breakpoint & 0.192 & 22.99 & $\mathrm{O}$ & 0.20 & 0.066 \\
\hline & Linear Model & 0.010 & 26.78 & 3.79 & 0.095 & $0.023^{*}$ \\
\hline & Linear Model & 0.005 & 5.79 & $\mathrm{O}$ & 0.03 & 0.119 \\
\hline & Breakpoint & 0.014 & 9.11 & 3.32 & 0.00 & 0.115 \\
\hline \multicolumn{7}{|c|}{ Pollinator Agents } \\
\hline \multirow{2}{*}{$\begin{array}{l}\text { Birds } \\
\left(\text { species } / 70 m^{2}\right)\end{array}$} & Linear Model & 0.000 & -37.12 & $\mathrm{O}$ & -0.02 & 0.855 \\
\hline & Breakpoint & 0.055 & -34.21 & 2.91 & -0.04 & 0.559 \\
\hline \multirow{2}{*}{$\begin{array}{l}\text { Insects } \\
\left(\text { species } / 7 \mathrm{Om}^{2}\right)\end{array}$} & Linear Model & 0.007 & 15.16 & $\mathrm{O}$ & 0.05 & 0.064 \\
\hline & Breakpoint & 0.015 & 16.59 & 1.43 & 0.06 & 0.549 \\
\hline \multirow{2}{*}{$\begin{array}{l}\text { Wind } \\
\left(\text { species } / 70 m^{2}\right)\end{array}$} & Breakpoint & 0.199 & 17.39 & $\mathrm{O}$ & 0.20 & 0.175 \\
\hline & Linear Model & 0.009 & 21.54 & 4.15 & 0.08 & $0.025^{*}$ \\
\hline \multicolumn{7}{|l|}{ Shade Tolerance } \\
\hline \multirow{2}{*}{$\begin{array}{l}\text { Low } \\
\left(\text { species } / 70 m^{2}\right)\end{array}$} & Linear Model & -0.000 & -1.09 & $\mathrm{O}$ & -0.02 & 0.822 \\
\hline & Breakpoint & -0.056 & 0.66 & 1.75 & -0.02 & 0.271 \\
\hline \multirow{2}{*}{$\begin{array}{l}\text { Moderate } \\
\left(\text { species } / 7 \mathrm{Om}^{2}\right)\end{array}$} & Breakpoint & 0.154 & 19.70 & $\mathrm{O}$ & 0.21 & 0.121 \\
\hline & Linear Model & 0.009 & 24.45 & 4.75 & 0.08 & 0.030* \\
\hline \multirow{2}{*}{$\begin{array}{l}\text { High } \\
\left(\text { species } / 70 m^{2}\right)\end{array}$} & Breakpoint & 0.119 & 25.44 & $\mathrm{O}$ & 0.12 & 0.912 \\
\hline & Linear Model & 0.010 & 25.69 & 0.25 & 0.08 & $0.029^{*}$ \\
\hline \multicolumn{7}{|c|}{ Drought Tolerance } \\
\hline \multirow{2}{*}{$\begin{array}{l}\text { Low } \\
\left(\text { species } / 70 m^{2}\right)\end{array}$} & Linear Model & 0.009 & 34.56 & $\mathrm{O}$ & 0.05 & 0.059 \\
\hline & Breakpoint & 0.103 & 36.92 & 2.36 & 0.04 & 0.372 \\
\hline \multirow{2}{*}{$\begin{array}{l}\text { Moderate } \\
\left(\text { species } / 7 \mathrm{Om}^{2}\right)\end{array}$} & Breakpoint & 0.087 & 16.86 & $\mathrm{O}$ & 0.19 & 0.341 \\
\hline & Linear Model & 0.011 & 17.28 & 0.42 & 0.14 & $0.005^{* *}$ \\
\hline \multirow{2}{*}{$\begin{array}{l}\text { High } \\
\left(\text { species } / 70 m^{2}\right)\end{array}$} & Linear Model & $-2 \mathrm{e}-05$ & -0.07 & $\mathrm{O}$ & -0.02 & 0.955 \\
\hline & Breakpoint & -0.033 & 1.06 & 1.13 & -0.07 & 0.411 \\
\hline
\end{tabular}

\subsubsection{Dominant Drivers of Native Seedling Diversity}

Within the initial abiotic and biotic linear mixed effect models analysed for dominant drivers, five variables were significant with at least $\mathrm{p}<0.05$ (Figure 13a, Figure 13b, Table 13). These dominant drivers were then included in the final LMM (Figure 13c). Drivers with the greatest likelihood of influencing seedling diversity were found to be all biotic variables mostly related to forest composition and structure (Table 13, Figure 13c). These covariates included herbaceous cover, canopy diversity, basal area, sapling diversity and the proportion of surrounding natural landcover. Herbaceous cover, canopy diversity and basal area showed the highest positive correlation ( $\mathrm{p}=0.0001, \mathrm{p}<0.01$ and $\mathrm{p}<0.01$ respectively) with seedling diversity 
(Table 13). Sapling diversity and the proportion of surrounding natural landcover showed smaller but still significant relationships with seedling diversity (both $\mathrm{p}<0.05$ ). The best model (Model 3, Table 13) represented $57 \%\left(\mathrm{R}^{2}\right)$ of the data on seedling diversity.
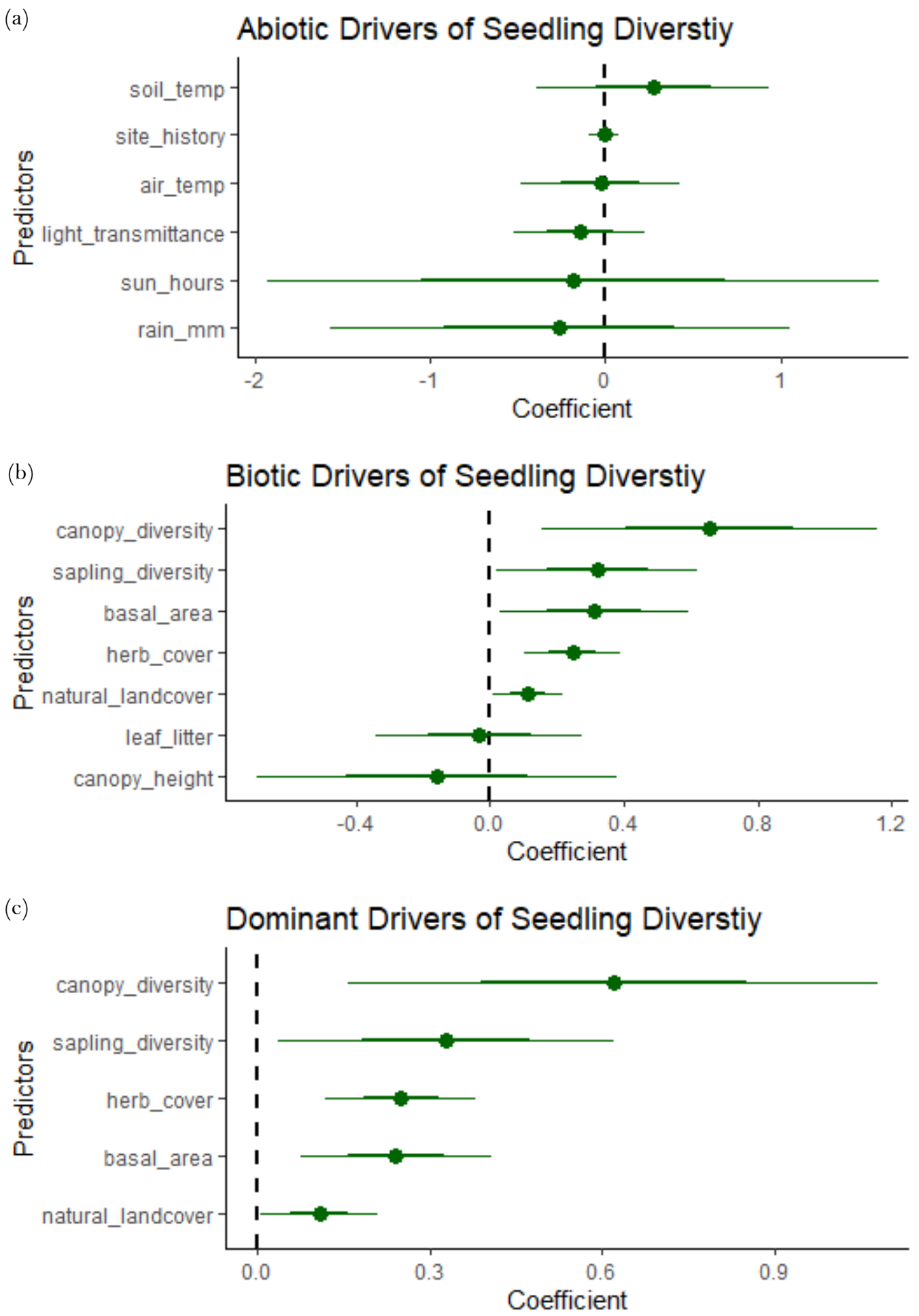

Figure 13: Mixed-effects models to predict potential drivers of seeding regeneration. Model 1 (a) includes all abiotic variables and Model 2 (b) includes all biotic variables thought to play a role in seedling regeneration. Model 3 (c) includes only the significant variables found Models 1 \& 2. The inner confidence interval of 1 standard 
deviation is represented by the thick line and the outer confidence interval of 2 standard deviations is represented by the thin line.

Table 13: Two way ANOVA of predictor variables for the three models. Model 1 includes all abiotic and Model 2 includes all biotic variables thought to play a role in seedling regeneration. Model 3 includes only the significant variables from Model 1 \& 2. Beta estimates are also included. Significance values were calculated using ANOVA. Significance codes: $*=p<0.05, * * *=p<0.01, * * * * 0<0.001, * * * * *=p<0.0001$.

\begin{tabular}{|c|c|c|c|c|}
\hline Predictors & $\begin{array}{r}\text { Beta } \\
\text { Estimate }\end{array}$ & Chisq & Df & $\operatorname{Pr}(>$ Chisq $)$ \\
\hline Model 1: Abiotic Drivers & & & \multicolumn{2}{|c|}{ AIC: $51.71, \mathrm{R}^{2}=0.03$} \\
\hline $\begin{array}{l}\text { Daily Air Temperature Range } \\
\left({ }^{\circ} \mathrm{C}\right)\end{array}$ & -0.026 & 0.016 & 1 & 0.896 \\
\hline Site History & -0.005 & 0.022 & 1 & 0.881 \\
\hline $\begin{array}{l}\text { Annual Sunshine } \\
\text { (hours) }\end{array}$ & -0.182 & 0.052 & 1 & 0.819 \\
\hline $\begin{array}{l}\text { Annual Rainfall } \\
(\mathrm{mm})\end{array}$ & -0.258 & 0.183 & 1 & 0.668 \\
\hline $\begin{array}{l}\text { Light Transmittance } \\
(\%)\end{array}$ & -0.147 & 0.726 & 1 & 0.394 \\
\hline $\begin{array}{l}\text { Daily Soil Temperature Variation } \\
\left({ }^{\circ} \mathrm{C}\right)\end{array}$ & 0.272 & 0.807 & 1 & 0.368 \\
\hline Model 1: Biotic Drivers & & & \multicolumn{2}{|c|}{ AIC: $17.53, \mathrm{R}^{2}=0.57$} \\
\hline $\begin{array}{l}\text { Leaf Litter Cover } \\
(\%)\end{array}$ & -0.031 & 0.052 & 1 & 0.819 \\
\hline $\begin{array}{l}\text { Canopy Height } \\
(\mathrm{m})\end{array}$ & -0.157 & 0.421 & 1 & 0.516 \\
\hline $\begin{array}{l}\text { Sapling Diversity } \\
\left(200 \mathrm{~m}^{2}\right)\end{array}$ & 0.320 & 5.584 & 1 & $0.0181 *$ \\
\hline $\begin{array}{l}\text { Surrounding Natural Landcover } \\
(\%<1 \mathrm{~km} \text { radius })\end{array}$ & 0.114 & 5.807 & 1 & $0.0159 *$ \\
\hline $\begin{array}{l}\text { Basal Area } \\
\left(\mathrm{m}^{2} / \mathrm{ha}\right)\end{array}$ & 0.312 & 6.025 & 1 & $0.0141 *$ \\
\hline $\begin{array}{l}\text { Canopy Diversity } \\
\left(200 \mathrm{~m}^{2}\right)\end{array}$ & 0.655 & 8.331 & 1 & $0.0038 * *$ \\
\hline $\begin{array}{l}\text { Herbaceous Cover } \\
(\%)\end{array}$ & 0.246 & 14.685 & 1 & $0.0001 * * *$ \\
\hline Model 3: Dominant Drivers & & & \multicolumn{2}{|c|}{ AIC: $14.00, R^{2}=0.57$} \\
\hline $\begin{array}{l}\text { Surrounding Natural Landcover } \\
(\%<1 \mathrm{~km} \text { radius })\end{array}$ & 0.109 & 5.406 & 1 & $0.0200 *$ \\
\hline $\begin{array}{l}\text { Sapling Diversity } \\
\left(200 \mathrm{~m}^{2}\right)\end{array}$ & 0.328 & 5.903 & 1 & $0.0151 *$ \\
\hline $\begin{array}{l}\text { Basal Area } \\
\left(\mathrm{m}^{2} / \mathrm{ha}\right)\end{array}$ & 0.241 & 9.971 & 1 & $0.0015 * *$ \\
\hline $\begin{array}{l}\text { Canopy Diversity } \\
\left(200 \mathrm{~m}^{2}\right)\end{array}$ & 0.619 & 8.392 & 1 & $0.0037 * *$ \\
\hline $\begin{array}{l}\text { Herbaceous Cover } \\
(\%)\end{array}$ & 0.249 & 16.995 & 1 & $3 \mathrm{e}-05 * * * *$ \\
\hline
\end{tabular}


Looking at the most significant drivers found in the LMM, we wanted to also assess their influence on seedling diversity independently of each other. We see that despite these 5 factors strongly predicting seedling diversity as a group, individually these factors are not as strong (Figure 14a-e). When assessed independently only canopy and sapling diversity remained significant predictors and only sapling diversity explained $>20 \%$ of the variability.
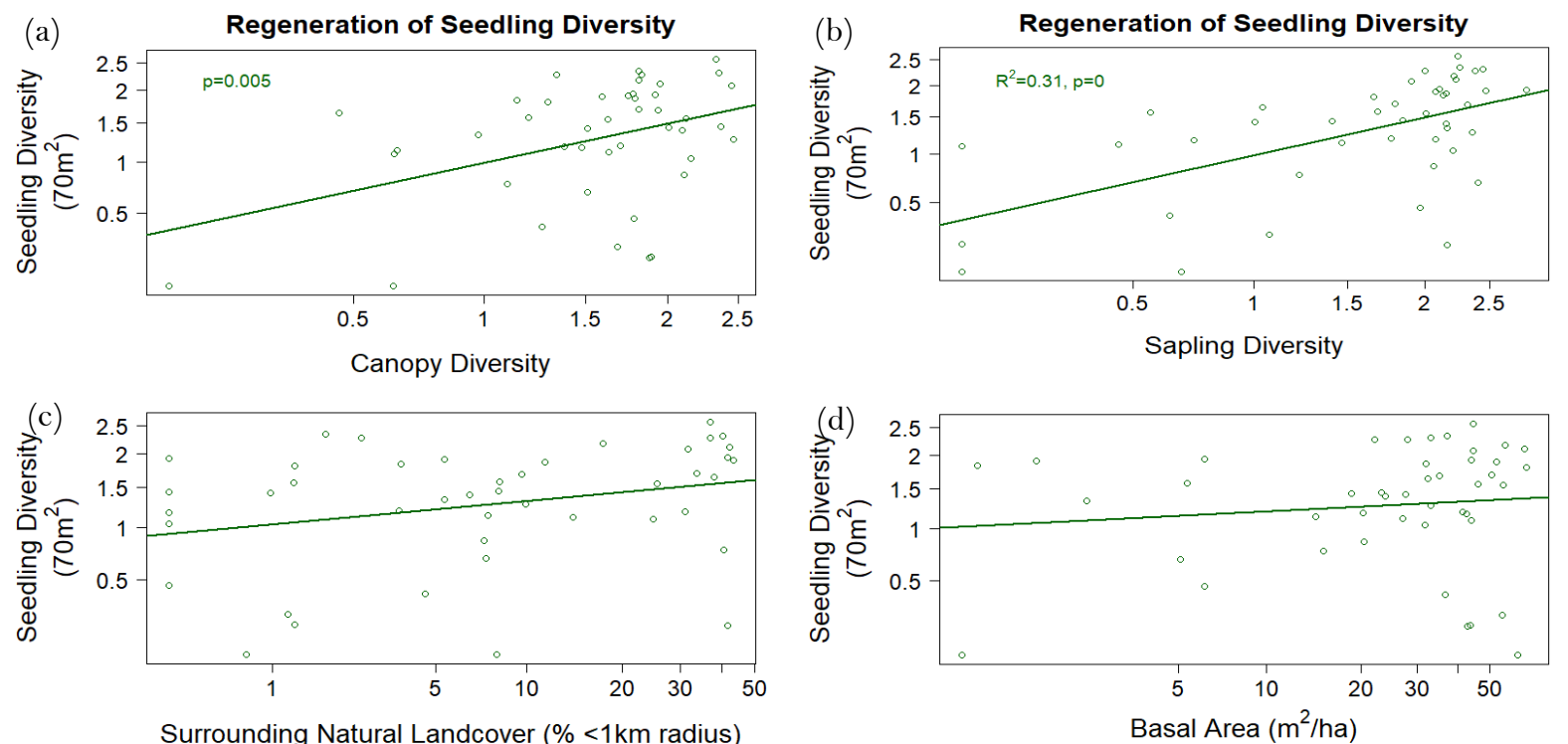

(e)

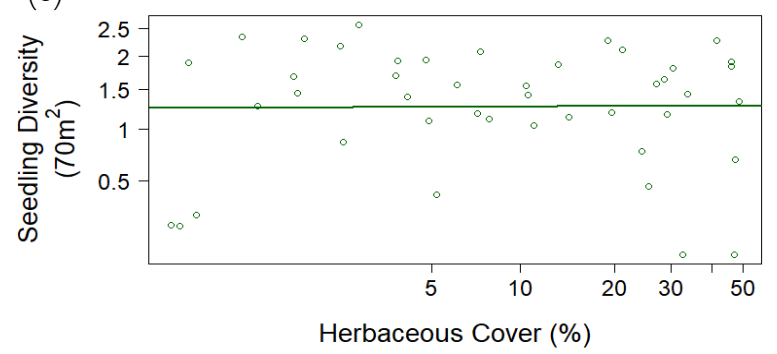

Figure 14: Linear regression models of dominant drivers indicated in the linear mixed-effects model. Variables were more significant as a group in the linear mixed-effect models than when assessed independently. Independent significant drivers of seedling regeneration were a) canopy diversity and b) sapling diversity. Non-significant independent drivers were c) proportion of surrounding natural landcover d) basal area and 3) herbaceous cover.

\subsection{Discussion}

\subsubsection{Patterns of Native Seedling Regeneration}

The linear regression models were helpful in assessing temporal trends within the regenerating native seedling community of planted urban forests. Our findings corroborate with other observations of naturally regenerating early successional forest communities, where certain 
seedling traits are more dominant than others (Grime, 2002; van Breugel et al., 2007). Early and mid-successional species readily inhabit forests which have reduced levels of exposure and closing canopies and are expected to be dominant in the early stages of forest development (Grime, 2002). This was the outcome in this study, with early successional species dominating the seedling community followed by mid-successional species, which showed half the richness. Few late successional species were found with only four sites having late-successional species present. Three sites had late-successional species present after 20 years of forest development, which might suggest that at this point the restored forests may have begun to progress towards an ecological state which supports the germination and survival of such species. This could be due to a combination of factors such as a drop in microclimate fluctuations and increase in basal area which occurred during this period and relates to a more stable climate and increased protection required by late-successional species. However, late-successional species require canopy gaps to establish and grow successfully (Muscolo et al., 2014). If dense canopy closure is homogenous across restored forests, late-successional species that do arrive are unlikely to establish due to a lack of available light. Another barrier to propagule arrival is a lack of available seed source. Seeds of late-successional trees lose viability quickly (Bazzaz, 1975) and are often large seeded and bird dispersed species (Moles \& Drake, 1999). Therefore, latesuccessional species are unlikely to germinate from a sites seedbank and will require bird populations to disperse seeds to isolated restored forests. Without strategies to link restored forests to surrounding natural landcover (i.e. other restored, regenerating or remnant native bush) or enrichment planting of late successional species, they are unlikely to establish.

The regenerating seedling communities were dominated by species which require insects for pollination, produce fruits as a reproductive strategy and attract frugivory agents for fruit dispersal. This indicates that many of the species arriving within the seedling community are doing so with the assistance of insect and bird populations. It has been reported by Meurk and Hall (2006) that the most successful dispersal events (seedling establishment) occur within $100 \mathrm{~m}$ of the propagule source for both wind and bird dispersed species. This highlights the need for our restored urban forests to both connect to surrounding natural landscapes and support the arrival of not only a diversity of plant species, but fauna as well, to complete the vegetation reproductive cycle. It is critical that restored urban forests attract a diversity of birds and invertebrates through all seasons to aid long term forest self-regeneration (Meurk \& Hall, 2006; Swanson et al., 2011). Wotton and McAlpine (2013) demonstrate the importance of forest structural complexity to attract invertebrate and bird populations to restored forests in New Zealand. Initial plantings of a diverse range of canopy species and height classes in addition to enrichment planting after canopy closure of diverse species traits to achieve 
structural complexity, will provide diverse habitat in the form of food sources, perches and nesting sites. Linking restoration sites to the surrounding forested landscapes using habitat corridors or planting forest patch 'stepping stones' are important tools to promote dispersal of seeds and pollination agents (Meurk \& Hall, 2006).

Restored urban forests in this study typify the classic plant communities expected of early successional forest ecosystems where shade and drought tolerant species are the dominant species traits (Weiher \& Keddy, 2001). Moderate to high shade and drought tolerant species had higher richness levels than species with low tolerance across the entire chronosequence. This indicates that canopy light transmittance has reduced to a level which can support these species to thrive. Moderate light transmittance levels are considered to be those between 20$40 \%$ transmittance (Sack \& Grubb, 2002) and the majority of restoration sites reached this target after 15 years. This is an indication that the developmental trajectory across the sites has started off well and conditions are on track to becoming suitable for late successional species to survive. Although there is little information available on expected timeframes for establishment of late successional species, it is known that they require protection and light to establish successfully. Without much appearance of late successional seedling species despite the moderate shade conditions and basal area (an indicator of biomass and level of available protection), these small urban forests may have plateaued at a point of arrested development, due to lack of seed source.

Tree seedlings were the most common plant growth form regenerating in the seedling community, but shrubs were also fairly common. Since shrubs were not typically present in the planted forest canopies (chapter 2), this suggests that they are regenerating from legacy seed banks or are arriving from surrounding forest patches. Over half the sites had a few shrub species naturally regenerating, supporting our recommendations in the previous chapter about the need to plant more shrubs species during both initial (light-loving) and enrichment (shadeloving) planting stages, as they are a key component and structural element of forest ecosystems and facilitate the recruitment of seedlings.

Ground ferns were only found at eight plots, and overall species richness of this plant group was low. Ferns are an iconic component of New Zealand's natural forested ecosystems and fern species can support the recovery of native canopy tree species (Carswell et al., 2007; Gallegos et al., 2015). For example, in young, open forest plantings, bracken ferns are known to be an important nursery species for native seedling regeneration (Gallegos et al., 2015). In shaded forested sites moderate ground cover of species such as crown ferns are associated with an increase in the presence of canopy trees such as Beilschmiedia tawa, Prumnopitys ferruginea and 
Dacrycarpus cupressinum (Carswell et al., 2007). Lianes and epiphytes were present at several sites but did not start to appear until approximately 15 years post planting. Barriers to lianes and epiphyte growth are known to be factors such as low basal area and high fluctuations in humidity (Wallace et al., 2017). This indicates that the restored forests after a few decades of growth, are on track to start supporting epiphytic communities, but as with other late successional plant guilds, the isolated nature of the urban forests may demand enrichment plantings of epiphytes (Wallace et al., 2017).

These results indicate that the first 10 years of forest growth is a critical period where many rapid changes are occurring within the seedling community, in relation to overall abundance and species richness of various plant traits. In comparison to canopy development, seedling community changes are occurring within a shorter time-frame of around 10 years, whereas significant breakpoints within the canopy occurred around 15 years. Dominant seedling traits which had significant breakpoints included early successional species, tree species and moderate shade and drought tolerance. Species diversity within the seedling community did not increase significantly with age. The seedling community had a similar diversity range and a species richness range double that of the planted forest canopy. This suggests many sites have seedling species arriving and surviving that are not within the immediate canopy. It is known that the seedling layer is often the most diverse layer within forest strata (Wardle, 1991) and the lack of species diversity may indicate low establishment numbers across each species that are arriving. This suggests that adaptive management activities are required to improve the abundance and richness of seedling establishment which will in turn improve seedling diversity within our planted urban forests.

\subsubsection{Drivers of Native Seedling Regeneration}

Due to the lack of significance found when looking at changes in seedling abundance and diversity and the low level of significance for species richness with forest age, it is evident that additional factors alongside planting age are driving native seedling regeneration. We hypothesized that a combination of factors were contributing to seedling diversity instead of one or two key drivers. Linear mixed-effect models were used to look at a combination of abiotic and biotic variables potentially driving seedling diversity. Dominant drivers were found to be solely biotic variables which represented canopy composition and structure and landscape dynamics. This suggests that biotic interactions are stronger predictors of seedling regeneration than abiotic factors within restored urban forests. Each predictor in the model output (Table 13) represents the additional effect of that co-variable to the model, with the 
effects of all other variables accounted for. Collectively, the drivers which predicted seedling diversity in order of the least contributing to the most important were the proportion of surrounding natural landcover, sapling diversity, basal area, canopy diversity and herbaceous cover.

Thrippleton et al. (2018) found large herbaceous biomass in forest communities of Central Europe to be the most important predictor for arrested succession, which resulted from severe understory competition. Our results also showed herbaceous cover to be the strongest predictor of seedling diversity. However, according to our model and contradictory to many other studies (McAlpine et al., 2015; Norton, 2009; Standish et al., 2001; Thrippleton et al., 2018; Vilà et al., 2011), native seedling diversity had a positive relationship with herbaceous cover as opposed to negative. The reason for this unusual result is unknown. It is important to note that delineation between native and exotic herbaceous cover was not done during the field surveys in this study. Instead an estimate of total herbaceous cover which included both native and exotic species was recorded. However, the majority of our sites were observed to have few native herbaceous plants, with native ground ferns being present at only seven of our study sites. Another contributing factor could be that the highest amount of herbaceous cover recorded across all sites was just over $50 \%$ and the majority of the remaining sites had around $30 \%$ herbaceous cover after 10 years of forest development. This equates to moderate levels of shade available, leaving adequate room for high levels of seedling diversity in the remaining $50-70 \%$ of open ground to establish.

Canopy diversity and basal area contributed with similar significance to seedling diversity. A diverse canopy supports increased forest structural complexity, basal area, spatial heterogeneity of light and diversity of microhabitats to support the regeneration of diverse seedling traits (Herrick et al., 2006; Kanowski et al., 2003; Lohbeck et al., 2012; Rissanen et al., 2019). While the results showed the levels of canopy diversity (1.5-2.5 on the shannon index) was enough to contribute significantly to the regeneration of seedling diversity across the sites, overall diversity of the forest canopies could be improved with enrichment planting efforts or increasing links to surrounding natural forest patches. Diversity levels within the seedling layer are often more diverse than the canopy tier in natural forest ecosystems, however we found the diversity index of the seedling community matched that of the canopy tier, indicating barriers to diverse seedling regeneration is present. The level of species richness in the seedling layer was double that of the canopy, suggesting that the low abundance of seedling species arriving and surviving may be contributing to low the seedling diversity index. 
It is often reported that canopy diversity drives seedling diversity, but sapling diversity is not as often studied or reported as a key driver of seedling regeneration. A diverse sapling layer could support natural regeneration by increasing forest structural complexity and stratification and contributing to the improvement of ecological processes. This highlights to importance of enrichment planting efforts after canopy closure to build up the understory layer or other strategies such as the creation of light wells to support understory species growth. These and other activities will help recover ecological integrity and create heterogenous habitat niches, which will have positive benefits to seedling growth and survival.

Restoration sites which are highly isolated, will often have a multitude of existing barriers effecting the capacity for natural self-regeneration. These barriers include an increased area of exposure and stressors from the surrounding unnatural environments (e.g. agricultural fields or urban landscape) and decreased capacity for propagule arrival due to a lack of dispersal agents or distances too great for successful dispersal (Stewart et al., 2009). Seed dispersal of New Zealand plant species is predominantly through anemochory (wind-dispersal) which is the method for $79 \%$ of our species, followed by endozoochory (ingestion by vertebrates) for $33 \%$ of native plant species and hydrochory (water) used by $28 \%$ of species (Thorsen et al., 2009). The most successful dispersal events are thought to occur within $100 \mathrm{~m}$ of the original propagule source (Meurk \& Hall, 2006). Therefore, the proportion of surrounding natural forest cover will greatly determine the level of diversity regenerating within planted forests. With an increase in natural forest cover within a $1 \mathrm{~km}$ radius of the restored forest plots, the final model suggests an associated increase in seedling diversity as a result, but this predictor was the least significant out of the five predictors tested.

The dominant drivers were found to be more significant when modelled as a group of predictors, than when viewed individually. When viewing these predictors independently of each other, only two remained significant. Despite herbaceous cover having the most significant effects amongst the five predictors in the final model, when considered by itself it was not significant. This reiterates the importance of considering a multitude of potential and interacting drivers and barriers when undertaking restoration programmes. Because the level of regeneration occurring within the seedling community is often not due to one or two key drivers but is influenced by a multitude of abiotic and biotic factors and includes both the direct and indirect relationships between each. No abiotic covariates in this study were found to play a significant role in seedling diversity. This contradicts with many other studies and should be noted that abiotic variables should not be excluded as important drivers despite our results suggesting otherwise. It is well known that abiotic factors such as climate, site history and 
light availability can be significant drivers or barriers to native seedling regeneration (ArroyoRodriguez et al., 2017; Badano et al., 2015; Borgmann \& Rodewald, 2005; Bose et al., 2016; Do Vale et al., 2015; Elgar et al., 2014; Gaviria \& Engelbrecht, 2015; Wallace et al., 2017). 


\subsection{Summary}

Ecological restoration is the process of assisting in the recovery of an ecosystem that has been degraded, damaged, or destroyed (SER 2004). With the mass removal of forests at large scales for anthropogenic purposes, a movement to restore what has been lost is underway by restoration practitioners, hopeful that in time planted forests will heal (Waldron \& Xi, 2013). Urban forest restoration is a complex process, requiring intervening management actions underpinned by ecological theory for decades after initial tree plantings (Waldron \& Xi, 2013). The Society of Ecological Restoration provides a list of nine ecosystem attributes related to forest form, function and structure as a guideline for measuring restoration success. However, three major attributes where considered to be key determinates of restoration success and included vegetation structure, species diversity, and ecological processes (Ruiz-Jaen 2005). When restoring urban forests from scratch to eventually form fully functioning forest ecosystems, a big picture approach to restoration is required. All ecological processes, plant growth forms and mutualistic fauna need to be reinstated. Because recreating forest structure and community composition without restoring function, or recreating function without structure or community composition falls short of complete ecological restoration (Reay \& Norton, 2002).

Results from this thesis indicate that the first 20 years of planted forest development exhibit major changes in canopy composition and structure, forest floor dynamics, microclimate stabilisation and the seedling community. This period saw a significant increase in canopy abundance, height, basal area and leaf litter and a significant decrease in light transmittance and herbaceous cover. Dominant species traits within the restored canopies and seedling communities were fairly representative of what is usually found within successfully restored or remnant forests in the early stages of ecosystem development. Restored forest canopies were dominated by early successional and pioneer species and small to medium-sized tree species. Regenerating seedling communities had high richness levels of early and mid-successional species, trees, shrubs and shade and drought tolerant species. Dominant reproductive and dispersal strategies highlight the importance of implementing adaptive management strategies which give added focus to restoring invertebrate and avifauna communities, to assist the completion of plant reproductive cycles and subsequent natural regeneration capacity. However, very few late successional plant guilds such as trees, lianes and epiphytes were found 
within the restored forests, indicating successional trajectories may have plateaued to a point of arrested development. This is likely due to a lack of seed source available to reinstate these late successional species or a lack of seed dispersal agents. Establishing these species with enrichment plantings or linking restored sites to surrounding forest patches may be required to bring these into the forest community sooner.

Collectively, five biotic drivers representing forest composition, structure and landscape factors strongly influenced seedling diversity. All drivers had a positive relationship with seedling diversity and included herbaceous cover, canopy diversity, basal area, sapling diversity and the proportion of surrounding natural landcover. The positive effect of herbaceous cover on seedling diversity within the group of coefficients was an unexpected result and contradicts the widely held belief that herbaceous cover is detrimental to seedling recruitment. However, the range of herbaceous cover for the majority of study sites was between $30-50 \%$, leaving adequate room for seedling regeneration to occur. The influence of each of these drivers on seedling diversity was more significant when assessed as a group than when viewed independently, reiterating the importance of considering a multitude of potential and interacting drivers and barriers when undertaking restoration programmes.

Relationships between city and forest planting age on the patterns of species similarity between study plots was assessed using NMDS analysis. The close proximity of same-city sites on the NMDS plots indicate that seedling and canopy communities are generally influenced by geography (city) and are less structured by forest planting age. This may be a reflection of the climatic conditions and biogeography characteristic of each city, or perhaps a commonality in restoration practice and management by the local councils and community groups within each city. Given the results of the univariate analyses of the chronosequence, it is somewhat surprising that a signal of planting age was not more obvious in the NMDS plots. The high stress values for both canopy and seedling communities in the NMDS analysis $(2.5 \%$ \& $2.3 \%$ respectively) sit just outside the recommended range $(<2 \%)$ which means the plots do not fully represent relative dissimilarity between sites.

Overall, the stem abundance of canopy individuals, species richness and subsequent diversity across all our study sites was low compared to levels found in more natural forest ecosystems and levels reported in publications on successful restoration programmes internationally (Hagihara et al., 2008; Kanowski et al., 2003; Richnau et al., 2012). These limitations are likely contributing to a lack of structural complexity within our urban forest canopies, creating barriers and driving the low levels of diversity found within the seedling community. 
One limitation of this study is that no natural forest sites were used as a point of comparison or reference. Therefore, we are unable to conclude whether the results are comparable to more natural forest ecosystems in New Zealand. Instead we have compared results to relevant studies conducted locally and internationally.

\subsection{Recommendations for Restoration Practice}

Restoration actions should be taken to facilitate the arrival of woody and non-woody species into restored urban forests. The spontaneous recolonization by desirable species is unlikely to occur in highly modified, fragmented urban contexts. Restoration programmes must evolve to incorporate a more holistic view of the ecological requirements needed for an urban forest ecosystem to become self-sustainable and take extra steps to meet them. Consideration into how one can improve the integrity of forest form, function and structure are important aspects that are missing when undertaking urban restoration planting programmes. Restoration of all forms of plant life and forest fauna are required to achieve a complete ecological restoration. Implementation of an ecological approach to ecosystem restoration using ecological knowledge is essential if we are to build ecologically sound, self-regenerating urban forest ecosystems from scratch.

A detailed long-term (10-20 years) multi-staged adaptive restoration plan is essential to guide practitioners on what is to be implemented along the various stages of a restoration programme. Such plans should include the overall vision, goals, actions, monitoring requirements and adaptive management strategies (Carreiro et al., 2008; Wallace \& Clarkson, 2019). Practitioners should aim for a forest canopy with high diversity and structural complexity by increasing planting densities and species richness and include a wide range of species traits related to form and function. Adaptative management strategies and monitoring should be implemented for the first 20 years as this is the period where many significant changes in urban forest composition, structure and function are occurring.

The following strategies should be considered when undertaking ecological restoration programmes:

- Before starting restoration, address the factors that limit natural regeneration and hence will also limit any planting success.

- Use ecological succession as a guide for when, what, where, how many and in what conditions species are to be planted. 
- Conduct diverse enrichment plantings of native trees, shrubs and non-vascular plants to enable diverse regeneration of species

- Reconstruct canopies that are stratified and contain high structural complexity and diversity by planting diverse structural classes, forms, height capacities, tolerances and other traits.

- Enrichment plantings of species which are lacking in available seed source or are slow to establish.

- Use a variety of spatial planting strategies such as planting randomly, non-linearly, in same-species groupings or use planting nodes.

- Consider strategies for landscape integration to improve chances of propagule arrival via wind or bird dispersal and improve invertebrate communities to assist pollination.

- Control of herbaceous, competitive weeds such as exotic grasses during the first 10 years of forest growth by planting a dense, species-rich and multi-tiered canopy.

- Long-term adaptive management to ensure site trajectory is heading in the direction desired. 


\section{REFERENCES}

Aerts, R., \& Honnay, O. (2011). Forest restoration, biodiversity and ecosystem functioning. BMC Ecol, 11(29), 29. doi:10.1186/1472-6785-11-29

Allen, R., et al. (2013a). New Zealand's indigenous forests and shrublands (pp. 34-48).

Allen, R. B. (1993). A permanent plot method for monitoring changes in indigenous forests: a field manual (pp. 35). Lincoln, New Zealand: Landcare Research.

Allen, R. B., et al. (2013b). New Zealand's indigenous forests and shrublands. In J. Dymond (Ed.), Ecosystem services in New Zealand: conditions $\&^{2}$ trends (1st ed., pp. 34-48). Lincoln, New Zealand: Manaaki Whenua Press.

Allen, R. B., et al. (2003). Developing a forest biodiversity monitoring approach for New Zealand. New Zealand Journal of Ecology, 27(2), 207-220. doi:10.2307/24055345

Archer, S., \& Pyke, D. A. (1992). Plant-animal interactions affecting plant establishment and persistence on revegetated rangeland. Biological Conservation, 61(1), 76-76. doi:10.1016/00063207(92)91243-1

Aronson, J., \& Alexander, S. (2013). Ecosystem Restoration is Now a Global Priority: Time to Roll up our Sleeves. Restoration Ecology, 21(3), 293-296. doi:10.1111/rec.12011

Arroyo-Rodriguez, V., et al. (2017). Multiple successional pathways in human-modified tropical landscapes: new insights from forest succession, forest fragmentation and landscape ecology research. Biological Reviews, 92(1), 326-340. doi:10.1111/brv.12231

Asanok, L., et al. (2013). Relationships between functional traits and the ability of forest tree species to reestablish in secondary forest and enrichment plantations in the uplands of northern Thailand. Forest Ecology and Management, 296, 9-23. doi:10.1016/j.foreco.2013.01.029

Auckland Regional Council. (2018). Auckland plan 2050. Auckland, New Zealand: Auckland Council.

Badano, E. I., et al. (2015). Microclimate and seeding predation as drivers of tree recruitment in humandisturbed oak forests. Forest Ecology and Management, 356, 93-100. doi:10.1016/j.foreco.2015.07.031

Bakker, J. P., et al. (1996). Why do we need permanent plots in the study of long-term vegetation dynamics? Journal of Vegetation Science, 7(2), 147-155. doi:10.2307/3236314

Bates, D. (2007). Linear mixed-effects models using S4 classes Lme-4 Package (Vol. 1.1-2 1).

Bazzaz, F. A. (1975). Plant Species Diversity in Old-Field Successional Ecosystems in Southern Illinois. Ecology, 56(2), 485-488. doi:10.2307/1934981

Beckage, B., et al. (2005). Survival of tree seedlings across space and time: estimates from long-term count data. Journal of Ecology, 93(6), 1177-1 184. doi:10.1111/j.1365-2745.2005.01053.x

Bellingham, P. J., et al. (1999). Tree species richness and turnover throughout New Zealand forests. Journal of Vegetation Science, 10(6), 825-832. doi:10.2307/3237307

Bellingham, P. J., et al. (2000). Review of permanent plots for long-term monitoring of New Zealand's indigenous forests (04782 1958X). Retrieved from Wellington, New Zealand:

Borgmann, K. L., \& Rodewald, A. D. (2005). Forest Restoration in Urbanizing Landscapes: Interactions Between Land Uses and Exotic Shrubs. Restoration Ecology, 13(2), 334-340. doi:10.1111/j.1526100X.2005.00042.X

Bose, A. K., et al. (2017). A three decade assessment of climate-associated changes in forest composition across the north-eastern USA. Journal of Applied Ecology, 54(6), 1592-1604. doi:10.1111/13652664.12917 
Bose, A. K., et al. (2016). Assessing the factors influencing natural regeneration patterns in the diverse, multi-cohort, and managed forests of Maine, USA. Journal of Vegetation Science, 27(6), 11401150. doi: $10.1111 / \mathrm{jvs} .12433$

Bradshaw, A. D. (1983). The Reconstruction of Ecosystems: Presidential Address to the British Ecological Society, December 1982. The Journal of Applied Ecology, 20(1), 1-17. doi: $10.2307 / 2403372$

Breed, M., et al. (2013). Which provenance and where? Seed sourcing strategies for revegetation in a changing environment. Conservation Genetics, 14(1), 1-10. doi:10.1007/s10592-012-0425-z

Brown, M. A. (2015). Vanishing nature : facing New Zealand's biodiversity crisis. Auckland, New Zealand: Environmental Defence Society Incorporated.

Capers, R. S., et al. (2005). Successional dynamics of woody seedling communities in wet tropical secondary forests. Journal of Ecology, 93(6), 1071-1084. doi:10.1111/j.1365-2745.2005.01050.x

Carreiro, M. M., et al. (2008). Ecology, Planning, and Management of Urban Forests. New York: NY: Springer New York.

Carswell, F. E., et al. (2007). Where do conifers regenerate after selective harvest?: A case study from a New Zealand conifer-angiosperm forest. Forest Ecology and Management, 253(1), 138-147. doi:10.1016/j.foreco.2007.07.011

Carter, D. L., \& Blair, J. M. (2013). Seed source has variable effects on species, communities, and ecosystem properties in grassland restorations. Ecosphere, 4(8), 1-16. doi:10.1890/es 13-00090.1

Catovsky, S., \& Bazzaz, F. A. (2002). Feedbacks between canopy composition and seedling regeneration in mixed conifer broad-leaved forests. Oikos, 98(3), 403-420. doi:10.1034/j.16000706.2002.980305.x

Chai, Y., et al. (2016). Plant functional traits suggest a change in novel ecological strategies for dominant species in the stages of forest succession. Oecologia, 180(3), 771-783. doi:10.1007/s00442-015-3483-3

Charles, L. S., et al. (2018). Species wood density and the location of planted seedlings drive early-stage seedling survival during tropical forest restoration. Journal of Applied Ecology, 55(2), 1009-1018. doi: $10.1111 / 1365-2664.13031$

Chazdon, R. L., et al. (2010). Composition and Dynamics of Functional Groups of Trees During Tropical Forest Succession in Northeastern Costa Rica. Biotropica, 42(1), 31-40. doi: $10.1111 / \mathrm{j} .1744-7429.2009 .00566 . x$

Clewell, A., \& Aronson, J. (2013). The SER primer and climate change. Ecological Management \& Restoration, 14(3), 182-186. doi:10.1111/emr.12062

Comita, L. S., \& Hubbell, S. P. (2009). Local neighborhood and species' shade tolerance influence survival in a diverse seedling bank. Ecology, 9O(2), 328-334. doi:10.1890/08-0451.1

de Souza, F. M., \& Batista, J. L. s. F. (2004). Restoration of seasonal semideciduous forests in Brazil: influence of age and restoration design on forest structure. Forest Ecology and Management, 191(1-3), 185-200. doi:10.1016/j.foreco.2003.12.006

Denslow, J. S., \& Guzman G, S. (2000). Variation in stand structure, light and seedling abundance across a tropical moist forest chronosequence, Panama. Journal of Vegetation Science, 11(2), 201-212. doi: $10.2307 / 3236800$

Do Vale, I., et al. (2015). Tree Regeneration Under Different Land-Use Mosaics in the Brazilian Amazon's "Arc of Deforestation". Environ Manage, 56(2), 342-354. doi:10.1007/s00267-0150500-6

Donoso, I., et al. (2017). Complementary Effects of Species Abundances and Ecological Neighborhood on the Occurrence of Fruit-Frugivore Interactions. Frontiers in Ecology and Evolution, 5(133), 12. doi: $10.3389 /$ fevo.2017.00133 
Duncan, R. S., \& Chapman, C. A. (2003). Tree-Shrub Interactions During Early Secondary Forest Succession in Uganda. Restoration Ecology, 11(2), 198-207. doi:10.1046/j.1526100X.2003.00153.X

Duryea, M. L., et al. (2000). Restoring the Urban Forest Ecosystem. University of Florida, Institute of Food and Agricultural Sciences: School of Forest Resources and Conservation, Florida Cooperative Extension Service.

Elgar, A. T., et al. (2014). Overcoming barriers to seedling regeneration during forest restoration on tropical pasture land and the potential value of woody weeds. Front Plant Sci, 5, 200. doi:10.3389/fpls.2014.00200

Environment Canterbury. (2012). Canterbury Regional Policy Statement 2013. Christchurch, New Zealand: Canterbury Regional Council.

Escobedo, F., et al. (2016). Spatio-Temporal Changes in Structure for a Mediterranean Urban Forest: Santiago, Chile 2002 to 2014. Forests, 7(6), 121. doi:10.3390/f7060121

Facelli, J. M., \& Pickett, S. T. A. (1991). Plant litter: its dynamics and effects on plant community structure. The Botanical Review, 1, 1-32.

Falster, D., \& Westoby, M. (2005). Tradeoffs between height growth rate, stem persistence and maximum height among plant species in a post-fire succession. Oikos, 111(1), 57-66. doi:10.1111/j.0030-1299.2005.13383.x

Forestry New Zealand. (2018). One Billion Trees Fund, Report on Policy and Design Recommendations Retrieved from Wellington, New Zealand:

Forrester, D. I. (2014). The spatial and temporal dynamics of species interactions in mixed-species forests: from pattern to process. Forest Ecology and Management, 312, 282-292. doi:10.1016/j.foreco.2013.10.003

Fu, D., et al. (2009). Patterns and relationships of plant traits, community structural attributes, and ecohydrological functions during a subtropical secondary succession in central Yunnan, Southwest China. Archives of Biological Sciences, 61(4), 741-749. doi:10.2298/abs0904741f

Gallegos, S. C., et al. (2015). Bracken fern facilitates tree seedling recruitment in tropical fire-degraded habitats. Forest Ecology and Management, 337, 135-143. doi:10.1016/j.foreco.2014.11.003

Garcia, L. C., et al. (2016). Restoration over time: is it possible to restore trees and non-trees in highdiversity forests? Applied Vegetation Science, 19(4), 655-666. doi:10.1111/avsc.12264

Gaviria, J., \& Engelbrecht, B. M. (2015). Effects of Drought, Pest Pressure and Light Availability on Seedling Establishment and Growth: Their Role for Distribution of Tree Species across a Tropical Rainfall Gradient. PLoS One, 1O(11), e0143955. doi:10.1371/journal.pone.0143955

Gilliam, F. S. (2007). The Ecological Significance of the Herbaceous Layer in Temperate Forest Ecosystems. BioScience, 57(10), 845-858. doi:10.1641/B571007

Gilman, A. C., et al. (2016). Recovery of floristic diversity and basal area in natural forest regeneration and planted plots in a Costa Rican wet forest. Biotropica, 48(6), 798-808. doi:10.1111/btp.12361

Gómez-Aparicio, L. (2009). The role of plant interactions in the restoration of degraded ecosystems: a meta-analysis across life-forms and ecosystems. Journal of Ecology, 97(6), 1202-1214. doi: $10.1111 / \mathrm{j} .1365-2745.2009 .01573 . x$

Gómez-Aparicio, L., et al. (2004). Applying Plant Facilitation to Forest Restoration: A Meta-Analysis of the Use of Shrubs as Nurse Plants. Ecological Applications, 14(4), 1128-1138. doi:10.1890/035084

Gray, A. N., \& Spies, T. A. (1997). Microsite Controls on Tree Seedling Establishment in Conifer Forest Canopy Gaps. Ecology, 78(8), 2458-2473. doi:10.1890/00129658(1997)078[2458:Mcotse $] 2.0 . C o ; 2$

Grime, J. P. (2002). Plant Strategies, Vegetation Processes, and Ecosystem Properties (Second ed.). 
Guariguata, M. R., \& Ostertag, R. (2001). Neotropical secondary forest succession: changes in structural and functional characteristics. Forest Ecology and Management, 148(1-3), 185-206. doi:10.1016/s0378-1127(00)00535-1

Hagihara, A., et al. (2008). Canopy Multilayering and Woody Species Diversity of a Subtropical Evergreen Broadleaf Forest, Okinawa Island. Pacific Science, 62(3), 363-367,370,372-376. doi: 10.2984/1534-6188(2008)62[363:CMAWSD]2.0.CO;2

Herrick, J. E., et al. (2006). Monitoring ecological processes for restoration projects. Journal for Nature Conservation, 14(3-4), 161-171. doi:10.1016/j.jnc.2006.05.001

Holl, K. D., et al. (2013). Testing heterogeneity-diversity relationships in tropical forest restoration. Oecologia, 173(2), 569-578. doi:10.1007/s00442-013-2632-9

Hotta, K., et al. (2015). Twenty-one years of stand dynamics in a 33-year-old urban forest restoration site at Kobe Municipal Sports Park, Japan. Urban Forestry \& Urban Greening, 14(2), 309-3 14. doi:10.1016/j.ufug.2015.03.005

Hurst, J., \& Allen, R. (2007). A permanent plot method for monitoring indigenous forests: field protocols (pp. 68). Lincoln, Canturbury: Landcare Research New Zealand.

Kanowski, J., et al. (2003). Development of forest structure on cleared rainforest land in eastern Australia under different styles of reforestation. Forest Ecology and Management, 183(1-3), 265280. doi:10.1016/S0378-1127(03)00109-9

Keesing, V. F., \& Wratten, S. D. (1998). Indigenous invertebrate components in ecological restoration in agricultural landscapes. New Zealand Journal of Ecology, 22(2), 99-104.

Kozlowski, T. T. (2002). Physiological ecology of natural regeneration of harvested and disturbed forest stands: implications for forest management. Forest Ecology and Management, 158(1-3), 195-22 1. doi:10.1016/s0378-1127(00)00712-x

Lamb, D., et al. (2005). Restoration of degraded tropical forest landscapes. Science, $310(5754)$, 16281632. doi:10.1126/science.1111773

Landcare Research. (2019). Landcover Database v4.1. Retrieved from https://lris.scinfo.org.nz/layer/48423-lcdb-v41-land-cover-database-version-41-mainlandnew-zealand/

Lander, J. P. (2018). Plots Coefficients from Fitted Models Coefplot Package (1.2.6 ed., Vol. 1.2.6).

Larson, J. E., et al. (2016). Regeneration: an overlooked aspect of trait-based plant community assembly models. Journal of Ecology, 104(5), 1284-1298. doi:10.1111/1365-2745.12613

Laughlin, D. C., \& Clarkson, B. A. (2018). Tree Seedling Survival Depends on Canopy Age, Cover and Initial Composition: Trade-offs in Forest Restoration Enrichment Planting. Ecological Restoration, 36(1), 52-61. doi:10.3368/er.36.1.52

$\mathrm{Li}, \mathrm{F}$., et al. (2005). Urban forest in China: Development patterns, influencing factors and research prospects. International Journal of Sustainable Development \& World Ecology, 12(2), 197-204. doi:10.1080/13504500509469630

Lohbeck, M., et al. (2012). Functional diversity changes during tropical forest succession. Perspectives in Plant Ecology, Evolution and Systematics, 14(2), 89-96. doi:10.1016/j.ppees.2011.10.002

Lusk, C. H., \& Ortega, A. (2003). Vertical structure and basal area development in second-growth Nothofagus stands in Chile. Journal of Applied Ecology, 4O(4), 639-645. doi:10.1046/j.13652664.2003.00827.x

Magurran, A. E. (2003). Measuring biological diversity. Oxford: Blackwell Pub.

Mansourian, S., \& Vallauri, D. (2014). Restoring Forest Landscapes: Important Lessons Learnt. Environmental Management, 53(2), 241-251. doi:10.1007/s00267-013-0213-7

Mansourian, S., et al. (2005). Forest restoration in landscapes : beyond planting trees. New York: Springer. 
Marchetto, K. M., et al. (2010). Plant spatial arrangement affects projected invasion speeds of two invasive thistles. Oikos, $119(9), 1462-1468$. doi:10.1111/j.1600-0706.2010.18329.x

Mark, A. F., et al. (1964). Forest Succession on landslides above Lake Thomson, Fiordland. New Zealand Journal of Botany, 2(1), 60-89. doi:10.1080/0028825X.1964.10428727

Mark, A. R., et al. (1989). Forest succession on landslides in the Fiord Ecological Region, southwestern New Zealand. New Zealand Journal of Botany, 27(3), 369-390. doi:10.1080/0028825x.1989.10414119

McAlpine, K. G., et al. (2015). Ecological impacts of ground cover weeds in New Zealand lowland forests. New Zealand Journal of Ecology, 39(1), 50-60.

McClain, C. D., et al. (2011). Successional Models as Guides for Restoration of Riparian Forest Understory. Restoration Ecology, 19(2), 280-289. doi:10.1111/j.1526-100X.2009.00616.x

McDonald, D., \& Norton, D. (1992). LIGHT ENVIRONMENTS IN TEMPERATE NEWZEALAND PODOCARP RAIN-FORESTS. New Zealand Journal of Ecology, 16(1), 15-22.

McPherson, E. (1993). Monitoring urban forest health. An International Journal Devoted to Progress in the Use of Monitoring Data in Assessing Environmental Risks to Man and the Environment, 26(2), 165174. doi:10.1007/BFo0547494

Meurk, C., \& Hall, G. M. J. (2006). Options for enhancing forest biodiversity across New Zealand's managed landscapes based on ecosystem modelling and spatial design. New Zealand Journal of Ecology, 30(1), 131-146. doi:10.2307/24056170

Meurk, C. D., \& Swaffield, S. R. (2000). A landscape ecological framework for indigenous regeneration in rural New Zealand-Aotearoa. Landscape and Urban Planning, 50(1-3), 129-144. doi:10.1016/s0169-2046(00)00085-2

Miyawaki, A. (2008). A Philosophical Basis for Restoring Ecologically Functioning Urban Forests: Current Methods and Results. In M. M. Carreiro, Y.-C. Song, \& J. Wu (Eds.), Ecology, Planning, and Management of Urban Forests (pp. 187-196). New York,: Springer.

Moles, A. T., \& Drake, D. R. (1999). Potential contributions of the seed rain and seed bank to regeneration of native forest under plantation pine in New Zealand. New Zealand Journal of Botany, 37(1), 83-93. doi:10.1080/0028825x.1999.9512615

Monks, J. M., et al. (2013). Selection of potential indicator species for measuring and reporting on trends in widespread native taxa in New Zealand. Wellington, New Zealand: Department of Conservation.

Morgenroth, J., \& Östberg, J. (2017). Measuring and monitoring urban trees and urban forests. In F. Francesco, K. v. d. B. C. C. ecil, \& F. Alessio (Eds.), Routledge Handbook of Urban Forestry: Routledge Handbooks Online.

Muscolo, A., et al. (2014). A review of the roles of forest canopy gaps. Journal of Forestry Research, 25(4), 725-736. doi:10.1007/s11676-014-0521-7

National Institute of Water and Atmospheric Research. (2019). Climate Summaries. Retrieved from https://www.niwa.co.nz/climate/summaries

Norton, D. A. (2009). Species invasions and the limits to restoration: learning from the New Zealand experience.(PERSPECTIVE)(Author abstract)(Report). Science, $\quad$ 325(5940), 569. doi:10.1126/science. 1172978

Norton, D. A., et al. (2018). Upscaling restoration of native biodiversity: A New Zealand perspective. Ecological Management \& Restoration, 19(S1), 26-35. doi:10.1111/emr.12316

Oksanen, J., et al. (2019). Community Ecology Package Vegan Package (Vol. 2.5-5).

Ostertag, R., et al. (2015). Using plant functional traits to restore Hawaiian rainforest. Journal of Applied Ecology, 52(4), 805-809. doi:10.1111/1365-2664.12413 
Overdyck, E., \& Clarkson, B. (2012). Seed rain and soil seed banks limit native regeneration within urban forest restoration plantings in Hamilton City, New Zealand. New Zealand Journal of Ecology, 36(2), 177-190.

Ozarski, J. N. (2015). Cooperation for Mutual Benefit: Opportunities for Primary Industry and the New Zealand Department of Conservation. Retrieved from Wellington, New Zealand:

Palik, B. J., \& Pregitzer, K. S. (1993). The Vertical Development of Early Successional Forests in Northern Michigan, USA. The Journal of Ecology, 81(2), 271. doi:10.2307/2261497

Peña-Domene, M., et al. (2016). Restored connectivity facilitates recruitment by an endemic largeseeded tree in a fragmented tropical landscape. Ecology, 97(9), 2511-2517. doi:10.1002/ecy.1459

Pickett, S. T., \& Cadenasso, M. L. (1995). Landscape ecology: spatial heterogeneity in ecological systems. Science, 269(5222), 331-334. doi:10.1126/science.269.5222.331

Porteous, T. (1993). Native forest restoration : a practical guide for landowners. Wellington, N.Z.: Queen Elizabeth the Second National Trust.

Prach, K., \& Walker, L. R. (2011). Four opportunities for studies of ecological succession. Trends in Ecology and Evolution, 26(3), 119-123. doi:10.1016/j.tree.2010.12.007

Proença, V., et al. (2012). From Abandoned Farmland to Self-Sustaining Forests: Challenges and Solutions. Ecosystems, 15(6), 881-882. doi:10.1007/s10021-012-9557-8

R Project. (2019). Correlation, Variance And Covariance (Matrices) R-core base package 'stats' (Vol. stats v3.6.1).

Rappaport, D. I., et al. (2015). A landscape triage approach: combining spatial and temporal dynamics to prioritize restoration and conservation. Journal of Applied Ecology, 52(3), 590-601. doi:10.1111/1365-2664.12405

Rastandeh, A. (2018). Urban biodiversity in an era of climate change: Towards an optimised landscape pattern in support of indigenous wildlife species in urban New Zealand. (PhD), Victoria University of Wellington, Wellington, New Zealand.

Reay, S. D., \& Norton, D. A. (2002). Assessing the Success of Restoration Plantings in a Temperate New Zealand Forest. Restoration Ecology, 7(3), 298-308. doi:10.1046/j.1526-100X.1999.72023.x

Richnau, G., et al. (2012). Creation of multi-layered canopy structures in young oak-dominated urban woodlands - The 'ecological approach' revisited. Urban Forestry \&' Urban Greening, 11 (2). doi:10.1016/j.ufug.2011.12.005

Rissanen, K., et al. (2019). Light interception in experimental forests affected by tree diversity and structural complexity of dominant canopy. Agricultural and Forest Meteorology, 278. doi:10.1016/j.agrformet.2019.107655

Rodrigues, R. R., et al. (2011). Large-scale ecological restoration of high-diversity tropical forests in SE Brazil. Forest Ecology and Management, 261(10), 1605-1613. doi:10.1016/j.foreco.2010.07.005

Rodríguez-García, E., et al. (2011). Effects of overstorey canopy, plant-plant interactions and soil properties on Mediterranean maritime pine seedling dynamics. Forest Ecology and Management, 262(2), 244-251. doi:10.1016/j.foreco.2011.03.029

Ruiz-Jaén, M. C., \& Aide, T. M. (2006). An integrated approach for measuring urban forest restoration success. Urban Forestry and Urban Greening, 4(2), 55-68. doi:10.1016/j.ufug.2005.09.002

Ruiz-Jaen, M. C., \& Mitchell Aide, T. (2005). Restoration Success: How Is It Being Measured? Restoration Ecology, 13(3), 569-577. doi:10.1111/j.1526-100X.2005.00072.x

Sack, L., \& Grubb, P. (2002). The combined impacts of deep shade and drought on the growth and biomass allocation of shade-tolerant woody seedlings. Oecologia, 131(2), 175-185. doi: 10.1007/s00442-002-0873-0 
Saunders, D. A., \& Hobbs, R. J. (1995). Habitat reconstruction: the revegetation imperative. In R. A. Bradstock, T. D. Auid, D. A. Keith, R. T. Kingsford, \& D. Lunney (Eds.), Conserving Biodiversity: Threats \& Solutions (pp. 104-1 12). Chipping Norton, NSW: Surrey Beatty \& Sons.

Sercu, B., et al. (2017). How tree species identity and diversity affect light transmittance to the understory in mature temperate forests. Ecology and Evolution, 7(24). doi:10.1002/ece3.3528

Smith, T., \& Huston, M. (1989). A theory of the spatial and temporal dynamics of plant communities. Vegetatio, 83(1-2), 49-69. doi:10.1007/bfo0031680

Society for Ecological Restoration International Science \& Policy Working Group. (2004). The SER International Primer on Ecological Restoration (2 ed.). Tuscon: Society for Ecological Restoration International.

Soliveres, S., \& Maestre, F. T. (2014). Plant-plant interactions, environmental gradients and plant diversity: a global synthesis of community-level studies. Perspectives in Plant Ecology, Evolution and Systematics, 16(4), 154-163. doi:10.1016/j.ppees.2014.04.001

Standish, R. J., et al. (2001). The impact of an invasive weed Tradescantia fluminensis on native forest regeneration. Journal of Applied Ecology, 38(6), 1253-1263. doi:10.1046/j.00218901.2001.00673.x

Stanturf, J., et al. (2012). Forest Landscape Restoration (Vol. 15). Dordrecht, Netherlands: Springer.

Stewart, G. H., et al. (2009). URban Biotopes of Aotearoa New Zealand (URBANZ) II: Floristics, biodiversity and conservation values of urban residential and public woodlands, Christchurch. Urban Forestry \& Urban Greening, 8(3), 149-162. doi:10.1016/j.ufug.2009.06.004

Sullivan, J., et al. (2009). Restoring native ecosystems in urban Auckland: urban soils, isolation, and weeds as impediments to forest establishment. New Zealand Journal of Ecology, 33(1), 60-71.

Swanson, M. E., et al. (2011). The forgotten stage of forest succession: early-successional ecosystems on forest sites (Vol. 9, pp. 117-125).

Takahashi, K., et al. (2003). Effects of understory dwarf bamboo on soil water and the growth of overstory trees in a dense secondary Betula ermanii forest, northern Japan. Ecological Research, 18(6), 767-774. doi:10.1111/j.1440-1703.2003.00594.x

Tambosi, L. R., et al. (2014). A Framework to Optimize Biodiversity Restoration Efforts Based on Habitat Amount and Landscape Connectivity. Restoration Ecology, 22(2), 169-177. doi: $10.1111 /$ rec. 12049

Tao, S., et al. (2016). Global patterns and determinants of forest canopy height. Ecology, 97(12), 32653270. doi: $10.1002 /$ ecy. 1580

Thomas, E., et al. (2014). Genetic considerations in ecosystem restoration using native tree species. Forest Ecology and Management, 333, 66-75. doi:10.1016/j.foreco.2014.07.015

Thorsen, M. J., et al. (2009). Seed dispersal systems in the New Zealand flora. Perspectives in Plant Ecology, Evolution and Systematics, 11 (4), 285-309. doi:10.1016/j.ppees.2009.06.001

Thrippleton, T., et al. (2018). Herbaceous competition and browsing may induce arrested succession in central European forests. Journal of Ecology, 106(3), 1120-1132. doi:10.1111/1365-2745.12889

Tilman, D., \& Lehman, C. (2001). Human-caused environmental change: impacts on plant diversity and evolution. Proceedings of the National Academy of Sciences of the United States of America, 98(10), 5433-5440. doi:10.1073/pnas.091093198

Trudgill, S. (2012). Nature's clothing and spontaneous generation? The observations of Thoreau and Dureau de la Malle on plant succession. Progress in Physical Geography, 36(5), 707-714. doi:10.1177/0309133312448390

Tulod, A. M., et al. (2019). Canopy manipulation as a tool for restoring mature forest conifers under an early-successional angiosperm canopy. Restoration Ecology, 27(1), 31-37. doi:10.1111/rec.12707 
van Breugel, M., et al. (2007). Species Dynamics During Early Secondary Forest Succession: Recruitment, Mortality and Species Turnover. Biotropica, 39(5), 610-619. doi:10.1111/j.17447429.2007.00316.x

Vayreda, J., et al. (2013). Patterns and drivers of regeneration of tree species in forests of peninsular Spain. Journal of Biogeography, 4O(7), 1252-1265. doi:10.1111/jbi.12105

Vilà, M., et al. (2011). Ecological impacts of invasive alien plants: a meta-analysis of their effects on species, communities and ecosystems. Ecology Letters, 14(7), 702. doi:10.1111/j.14610248.2011.01628.x

Von Arx, G., et al. (2012). Spatio-temporal effects of forest canopy on understory microclimate in a long-term experiment in Switzerland. Agricultural and Forest Meteorology, 166 167, 144. doi:10.1016/j.agrformet.2012.07.018

Waldron, J. D., \& Xi, W. M. (2013). Forest Restoration: Simple Concept, Complex Process. Forest Research Open Access, 2(1), 2. doi: 10.4172/2 168-9776.1000e104

Walker, L. R., et al. (2003). Colonization dynamics and facilitative impacts of a nitrogen-fixing shrub in primary succession. Journal of Vegetation Science, 14(2), 277-290. doi:Doi 10.1658/11009233(2003)0 14[0277:Cdafio $] 2.0 . C 0 ; 2$

Wallace, K. J., \& Clarkson, B. D. (2019). Urban forest restoration ecology: a review from Hamilton, New Zealand. Journal of the Royal Society of New Zealand, <xocs:firstpage xmlns:xocs=""'/>. doi:10.1080/03036758.2019.1637352

Wallace, K. J., et al. (2017). Exotic weeds and fluctuating microclimate can constrain native plant regeneration in urban forest restoration. Ecological Applications, 27(4), 1268-1279. doi: $10.1002 /$ eap. 1520

Wardle, P. (1991). Vegetation of New Zealand (0521258731). Retrieved from

Weiher, E., \& Keddy, P. A. (2001). Ecological assembly rules : perspectives, advances, retreats. Cambridge: Cambridge University Press.

Wellington Regional Council. (2013). Regional Policy Statement for the Wellington Region. Wellington, New Zealand: Greater Wellington Regional Council.

Wilson, J., et al. (1992). Egler concept of initial floristic composition in succession - ecologist citing it don't agree what it means. Oikos, 64(3), 591-593.

Wingard, G. L., et al. (2017). The Role of Paleoecology in Restoration and Resource ManagementThe Past As a Guide to Future Decision-Making: Review and Example from the Greater Everglades Ecosystem, U.S.A. Frontiers in Ecology and Evolution, 5. doi: $10.3389 /$ fevo.2017.00011

Wortley, L., et al. (2013). Evaluating Ecological Restoration Success: A Review of the Literature. Restoration Ecology, 21(5), 537-543. doi:10.1111/rec.12028

Wotton, D. M., \& McAlpine, K. G. (2013). Predicting native plant succession through woody weeds in New Zealand. Wellington: Department of Conservation.

Wyse, S. V., et al. (2018). New Zealand forest dynamics : a review of past and present vegetation responses to disturbance, and development of conceptual forest models. New Zealand Journal of Ecology, 42(2), 87-106. doi:10.20417/nzjecol.42.18

Zahawi, R. A., \& Augspurger, C. K. (2006). Tropical Forest Restoration: Tree Islands As Recruitment Foci In Degraded Lands Of Honduras. Ecological Applications, $16(2)$, 464-478. doi:10.1890/10510761(2006)0 16[0464:TFRTIA $] 2.0 . C O ; 2$

Zeunert, J. (2013). Challenging Assumptions in Urban Restoration Ecology. Landscape Journal, 32(2), 231-242. doi:10.3368/1j.32.2.231 


\section{APPENDIX 1: LANDCOVER \& LAND-USE INFORMATION}

Table 14: Broad landcover categories and the specific landcover classes included. Retrieved from LCDB 4.1 (Landcare Research, 2019)

\begin{tabular}{ll}
\hline Broad Categories & Specific landcover classes included \\
\hline Built-up Area & Built-up area (settlement). \\
Exotic Forest & $\begin{array}{l}\text { Deciduous hardwoods, exotic forest and forest-harvested. } \\
\text { Mixed Exotic Shrubland }\end{array}$ \\
$\begin{array}{l}\text { Gorse and/or broom and mixed exotic shrubland. } \\
\text { Croplands }\end{array}$ & $\begin{array}{l}\text { High producing exotic grassland, low producing exotic grassland, orchard } \\
\text { vineyard or other perennial crop and short-rotation cropland. }\end{array}$ \\
Urban Parkland & Urban parkland/open space. \\
Other Exotic Landcover & Surface mine or dump and transport infrastructure. \\
Indigenous Forest & $\begin{array}{l}\text { Broadleaved indigenous hardwoods, indigenous forest and manuka and/or } \\
\text { kanuka. }\end{array}$ \\
Saline / Freshwater & Lake, pond, river, saline \\
Other Native Landcover: & $\begin{array}{l}\text { Herbaceous freshwater vegetation, herbaceous saline vegetation, sand or } \\
\text { gravel and gravel or rock. }\end{array}$ \\
\end{tabular}

Table 15: Detailed descriptions of the specific landcover classes that sit within the broad landcover categories: Retrieved from LCDB 4.1 (Landcare Research, 2019)

\begin{tabular}{|c|c|c|}
\hline Environment & Landcover & Definitions \\
\hline Exotic & $\begin{array}{l}\text { Built-up Area } \\
\text { (settlement) }\end{array}$ & $\begin{array}{l}\text { Built-up areas comprise central business districts, suburban dwellings, } \\
\text { commercial and industrial areas, and horticultural sites dominated by } \\
\text { structures and sealed surfaces (e.g., glasshouses). The class includes } \\
\text { immediately associated hard surfaces and infrastructure such as roads, carparks } \\
\text { and paved areas. Low density residential areas are also included }\end{array}$ \\
\hline Exotic & $\begin{array}{l}\text { Deciduous } \\
\text { Hardwoods }\end{array}$ & $\begin{array}{l}\text { Typically willow and poplar species growing adjacent to inland water and } \\
\text { rivers, this class also includes stands of planted exotic deciduous hardwoods. }\end{array}$ \\
\hline Exotic & Exotic Forest & $\begin{array}{l}\text { Exotic forest consisting of conifers other than Pinus radiata, such as Douglas } \\
\text { fir, macrocarpa, and larch, or evergreen broad-leaved species, such as Acacia } \\
\text { and Eucalyptus. This class also includes stands of wilding pines (i.e. usually } \\
\text { Corsican, Contorta and Ponderosa Pine), as far as they are identifiable in the } \\
\text { satellite imagery. }\end{array}$ \\
\hline Exotic & Forest - Harvested & $\begin{array}{l}\text { Areas showing evidence of harvesting since LCDB1, e.g. forest canopy } \\
\text { openings, skidder tracking, new roading or log landings. }\end{array}$ \\
\hline Exotic & $\begin{array}{l}\text { Gorse and/or } \\
\text { Broom }\end{array}$ & $\begin{array}{l}\text { Where low site fertility, extensive grazing and fire facilitate the plants' spread } \\
\text { and } \\
\text { establishment. Gorse and/or broom will reach heights of } 1-2 \mathrm{~m} \text { and are } \\
\text { typical of land subject to frequent physical disturbance such as aggrading } \\
\text { riverbeds, road cuttings, and firebreaks. }\end{array}$ \\
\hline Exotic & $\begin{array}{l}\text { High Producing } \\
\text { Exotic Grassland }\end{array}$ & $\begin{array}{l}\text { This class comprises areas of exotic grassland characterised by a spectral } \\
\text { signature indicating good vigour of the vegetation cover. Typically, these areas } \\
\text { are intensively managed exotic grasslands, rotationally grazed for wool, lamb, } \\
\text { beef, dairy, and deer production. These pastures are usually found on land that } \\
\text { can be cultivated and are subject to a 'long-rotational' cycle with pasture } \\
\text { renewal every } 5-10 \text { years. Productivity is enhanced through fertiliser } \\
\text { application and in some areas, irrigation. Dominant species are usually clovers }\end{array}$ \\
\hline
\end{tabular}


Exotic Low Producing Grassland

Exotic

Exotic

Exotic

Exotic

Exotic

Exotic

Native

Native

Native

Native

Mixed Exotic Shrubland Crops

Short-rotation Cropland Dump

Transport Infrastructure

Urban Parkland/Open Space

Broadleaved Indigenous Hardwoods Water
(Trifolium spp.) and highly productive pasture grasses, such as ryegrass (Lolium perenne) and cocksfoot

(Dactylis glomerata).

This class comprises areas of exotic and indigenous grasslands characterised by a spectral signature indicating lower plant vigour and biomass compared to Class 'High Producing Exotic Grassland'. The reduced vigour reflects lower levels of inherent soil fertility, lower fertiliser application, seasonal drought, or a shorter growing season, especially in the South Island. Typically, the class comprises extensively managed grasslands grazed for wool, sheep-meat and beef production. Dominant species are less productive exotic grasses, such as browntop (Agrostis capillaris) and sweet vernal (Anthoxanthum odoratum), usually mixed with indigenous short tussock species. Areas of Low Producing Grassland show a tendency to "brown off" during summer months. This class also includes areas of short tussock grassland such as hard tussock (Festuca novaezelandiae), blue tussock (Poa colensoi), and / or silver tussock (Poa cita).

Single-species or mixed communities of introduced shrubs and climbers, such as boxthorn, hawthorn (Crataegus spp.), elderberry (Sambucus spp.), brier (Rosa rubiginosa), buddleja (Buddleja davidii), blackberry (Rubus spp.), and old man's beard (Clematis vitalba). The class also includes areas of amenity planting where the shrubland component reaches 1 ha.

Orchard, Vineyard Orchards and areas cultivated less than annually, and used for producing tree or other Perennial

such as pip fruit, stone fruit, nuts, olives, and citrus fruit, as well as crops grown on shrubs or climbing plants, such as berries, kiwifruit, and asparagus.

Land generally found within the developed agricultural landscape on plains, terraces and down-land having a spectral signature indicating that soil has been exposed by cultivation or indicating crop types that typically involve regular, at least, annual cultivation. The class includes land used for growing cereal crops, root crops, annual seed crops, annual vegetable crops, hops, strawberry fields, annual flower crops, and open ground nurseries.

Surface Mine or Dump: Areas used for the surface disposal of solid waste material. Mine: Culturally derived bare surfaces such as gravel pits and other open quarries. Includes artificial surfaces such as roads, railroads, airport runways and skid sites associated with forest logging, where these features are discernable and exceed the 1 ha MMU.

Open, typically mown, grassed amenity areas within or associated with builtup areas. The class includes parks with scattered trees, playing fields, cemeteries, airports, golf courses, and river berms.

The class includes low-growing, coastal broadleaved forest. Characteristic is the presence of a mix of broad-leaved, generally seral hardwood species, such as wineberry (Aristotelia serrata), mahoe (Melicytus ramiflorus), Pseudopanax spp., Pittosporum spp., Fuchsia spp., ngaio (Myoporum laetum), and titoki (Alectryon excelsus), together with tutu (Coriaria spp.) and tree ferns. The presence of this

class usually indicates an advanced successional stage back to indigenous forest.

Estuarine Open Areas of standing or flowing open water without emerging vegetation, where occasionally or periodically saline waters are diluted by freshwater, or freshwater is made saline. The class includes the estuaries of rivers, lagoons, and dune swales.

Herbaceous Areas dominated by herbaceous aquatic vegetation as a component of Freshwater freshwater wetlands, i.e. the plants emerge over freshwater or grow in Vegetation freshwater saturated soils. The vegetation is dominated by sedges (Cyperaceae), rushes (Juncaceae), or tall erect herbs from other families (Poaceae, Restionaceae, Typhaceae). The class also includes areas of lowgrowing dicotyledon herbs and areas of sphagnum moss.

Herbaceous Saline Areas dominated by herbaceous aquatic vegetation as a component of estuarine Vegetation or coastal wetlands, i.e. the plants emerge over saline or brackish water or grow in saltwater saturated soils. Most areas of Herbaceous Saline Vegetation are subject to tidal changes in water level. The vegetation is dominated by salt- 
tolerant plants, such as Schoenoplectus spp., Apodasmia similis, or glasswort (Sarcocornia quinqueflora).

Native

Native Lake or Pond

Native

Native

River

Native

Sand or Gravel (coastal)

Native

Gravel or Rock (river and lakeshore)
Manuka and/or Kanuka
Classification of indigenous forest classes using satellite imagery has not been attempted for LCDB2. A national programme establishing permanent plots throughout all indigenous forest and scrub mapped in LCDB1, began in 2002. Ground data from this programme and other survey records may be used to update indigenous forest classes at a later date. Indigenous forest is defined as vegetation dominated by indigenous tall forest canopy species.

Areas of permanently or intermittently, standing open fresh water without emerging vegetation (lacustrine systems). The class includes natural water bodies, such as lakes and ponds, as well as artificial water bodies, such as oxidation ponds, fire control ponds, and reservoirs.

Indigenous shrubland found throughout New Zealand often associated with lightly grazed hill country. Typically found as early successional scrub type on previously forested land with a history of burning to control scrub reversion. Presence of mature stands signifies an advanced stage of reversion, also indicated by the presence of broadleaved forest species. Manuka

(Leptospermum scoparium) or kanuka (Kunzea ericoides) can be dominant, but they also occur in mixtures.

Areas of flowing open freshwater without emerging vegetation (riverine systems). The class includes natural and modified rivers, creeks, canals, and channels.

The coastal strip of land that falls on the landward side of the "coastline" as defined in the NZ Topo data.

Areas adjacent to rivers, streams and lakes characterised by bare gravel, sand and rock.

These are generally recent surfaces and vegetation, if present, is not apparent in the imagery, although lichen and moss cover may be extensive. The class also includes areas of bare ground associated with thermal activity.

Table 16: Historical land-use categories and descriptions.

\begin{tabular}{ll}
\hline Historical Land-use & Description \\
\hline Production & $\begin{array}{l}\text { Any type of horticultural, agricultural or other production } \\
\text { landscape. }\end{array}$ \\
Grassland & Un-utilised open grassland space or grassed public areas. \\
Exotic Forest & Any type of pure or mixed exotic forested areas. \\
Landfill & Previously used for landfill and then covered. \\
\hline
\end{tabular}




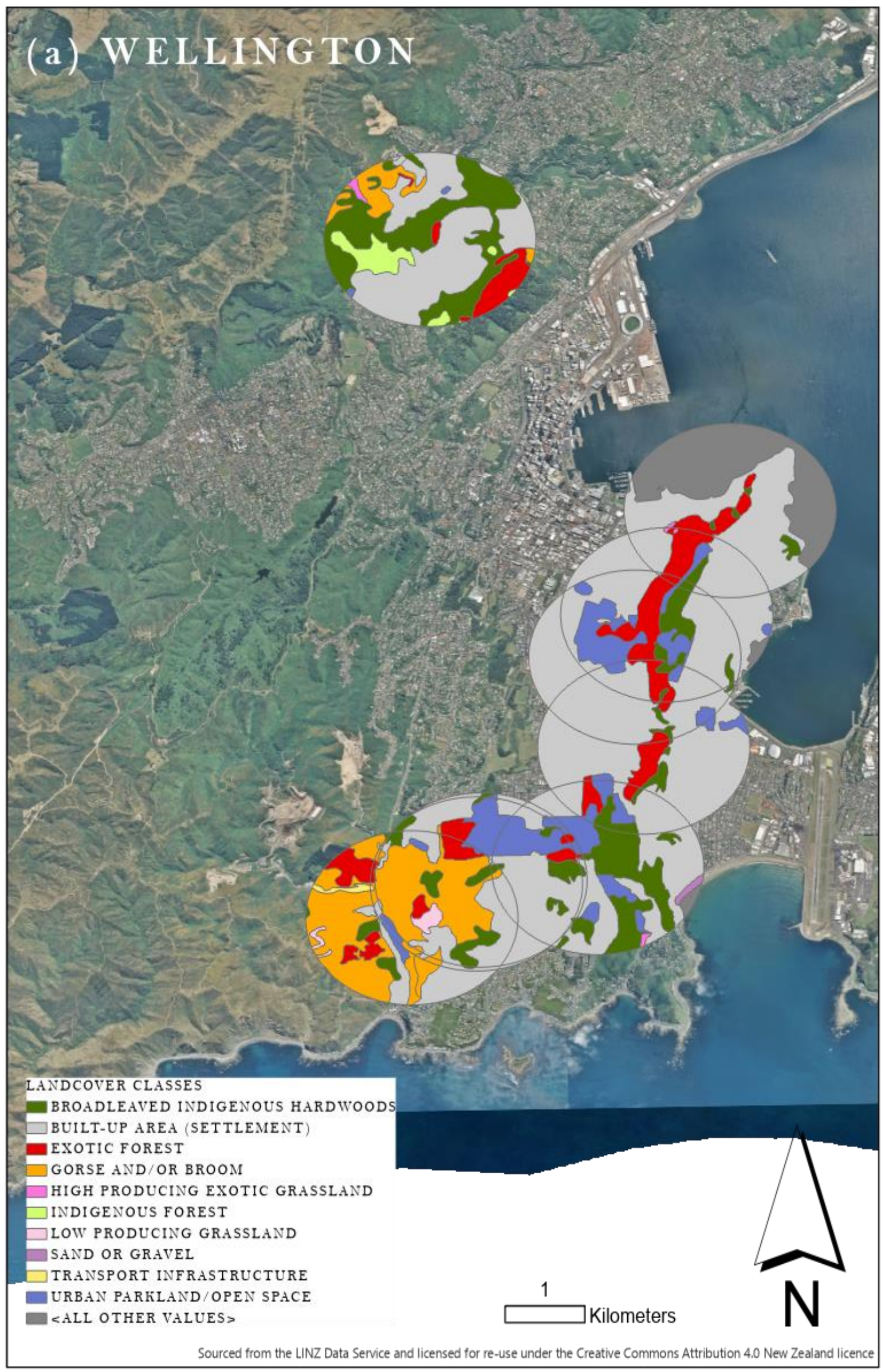




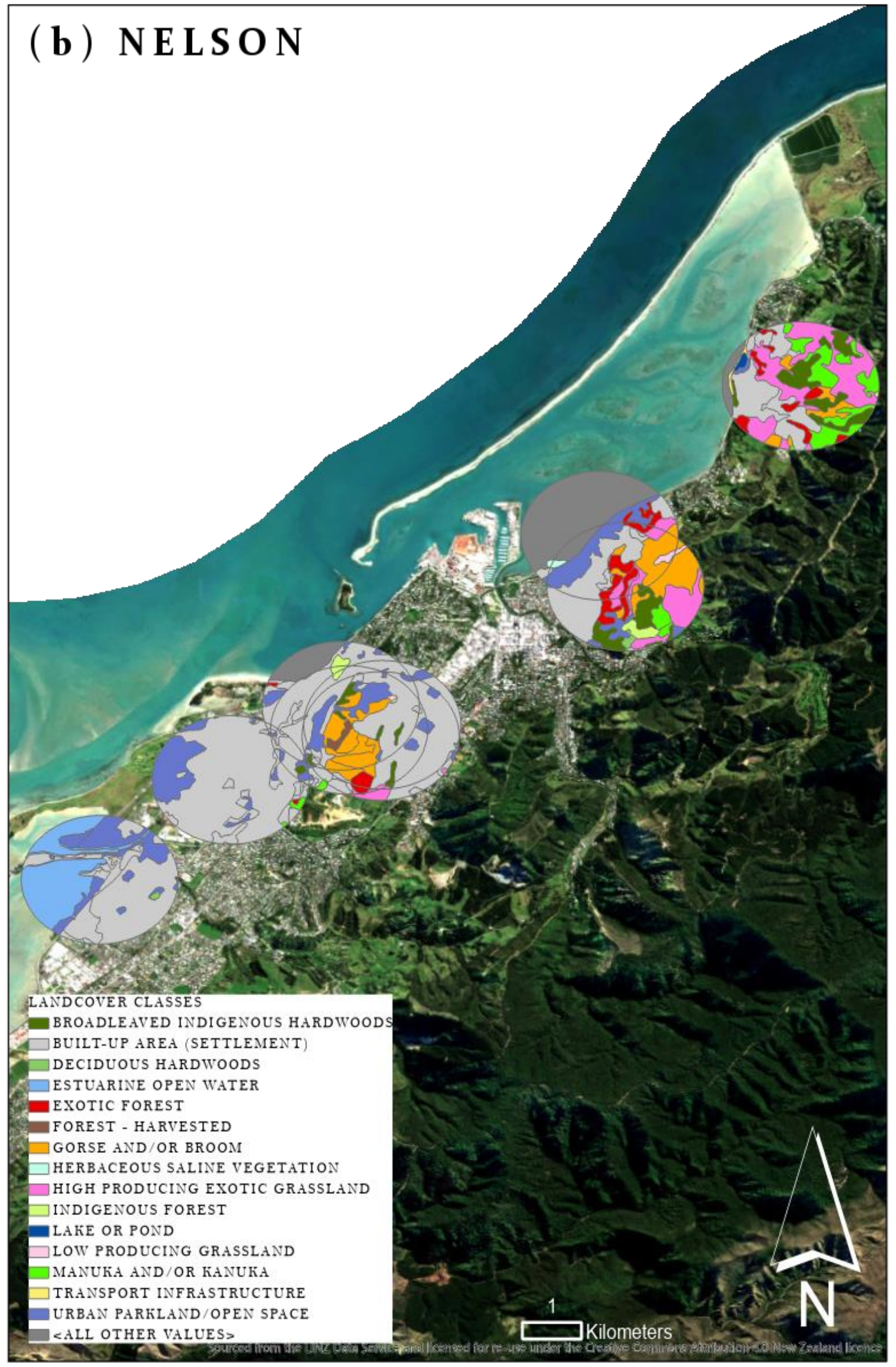




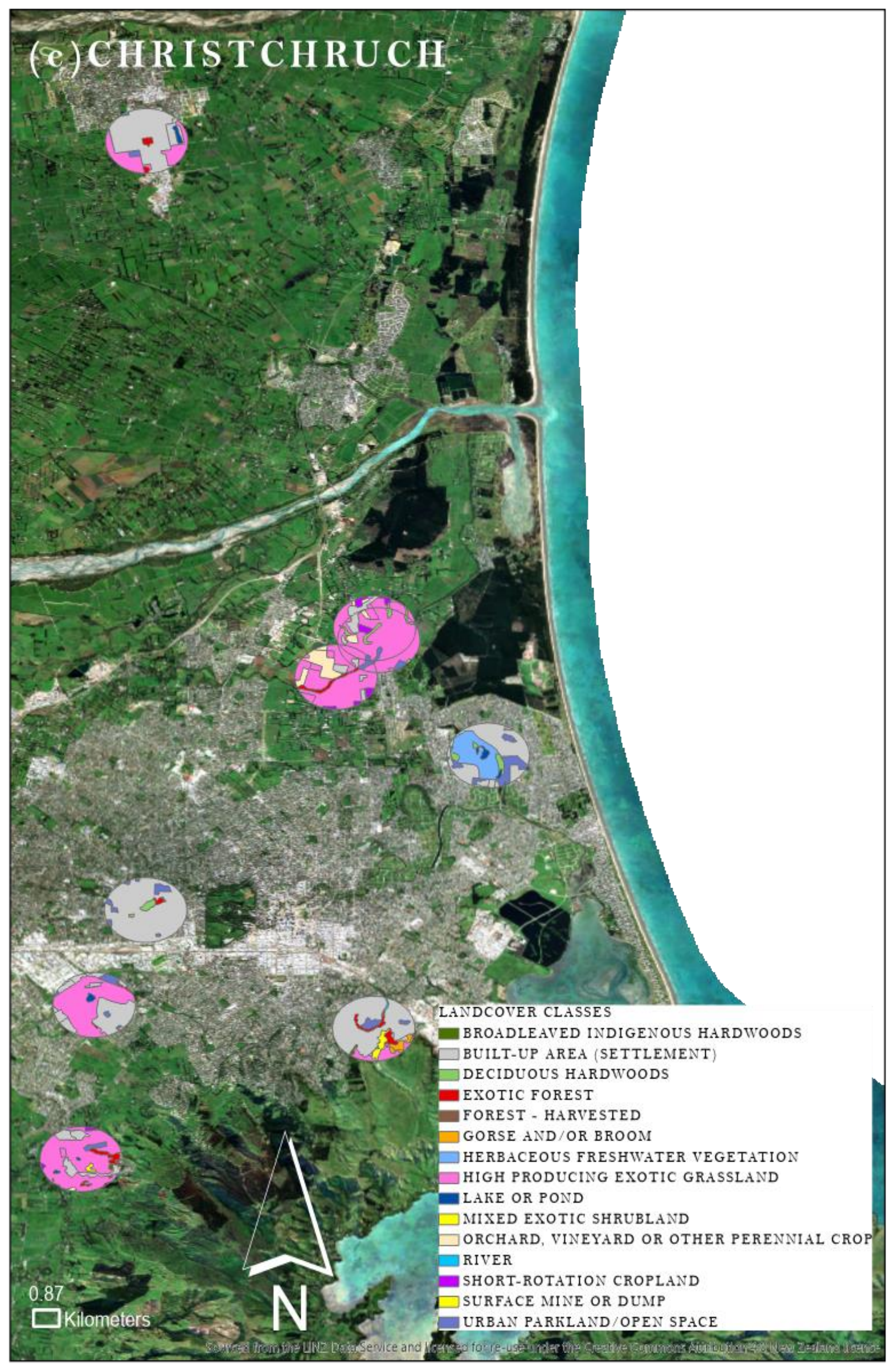




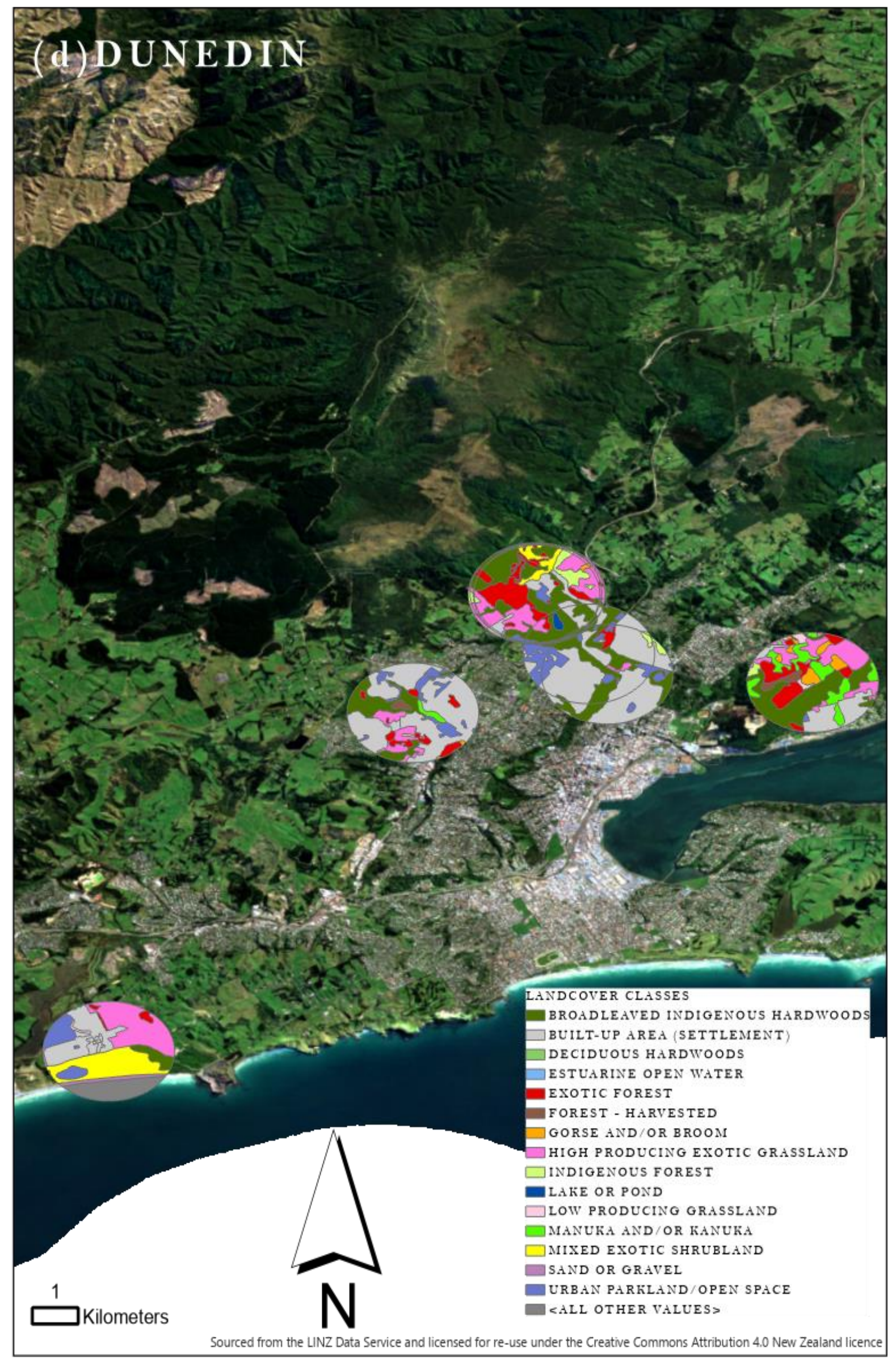




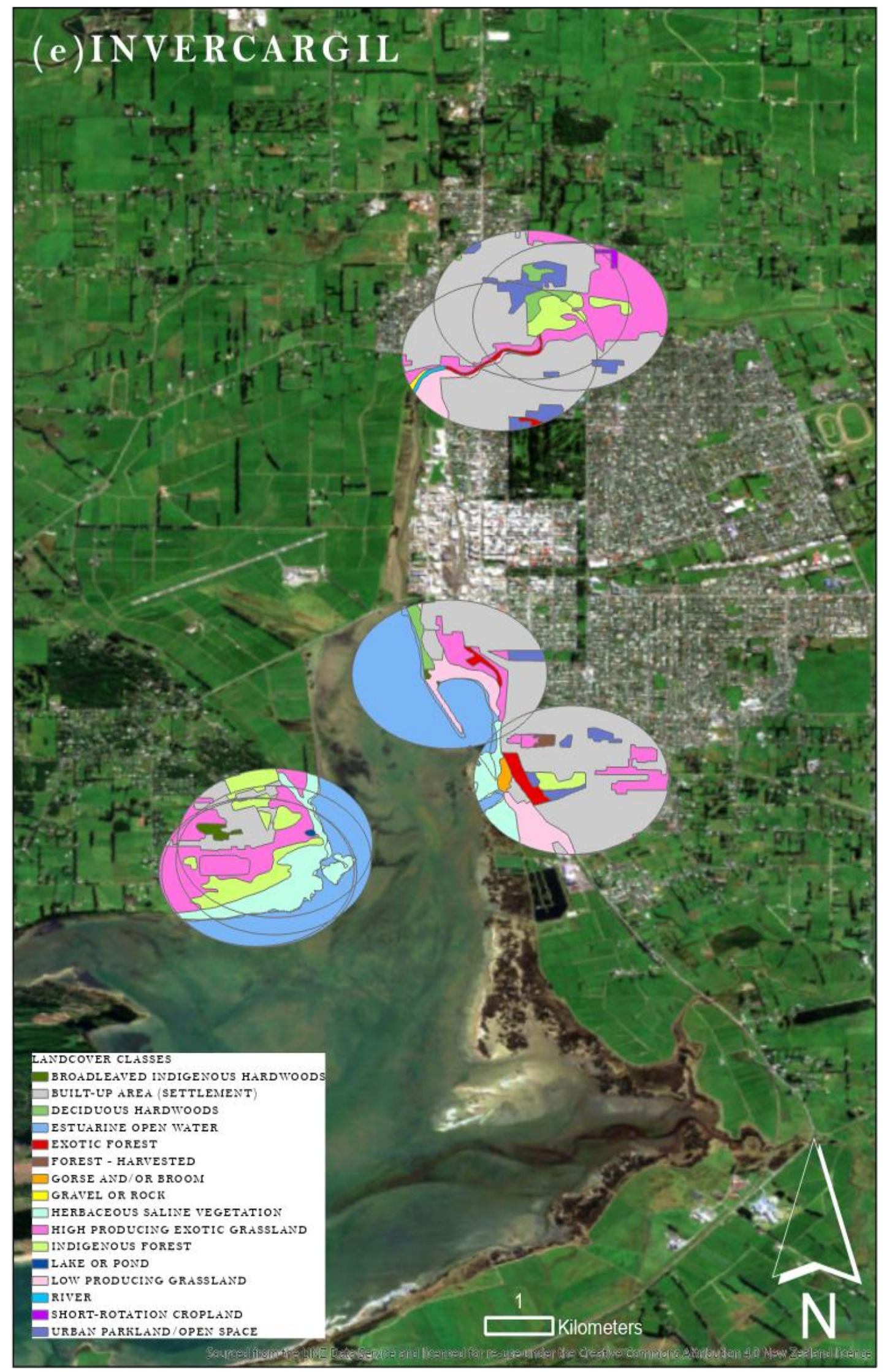

Figure 15: Regional landcover polygons. Created using LCDB v4.1 and produced on ARCmap. Locations are a) Wellington, b) Nelson, c) Christchurch, d) Dunedin and e) Invercargill. Each circle has a radius of $1 \mathrm{~km}$. 
Table 17: Presence and dominance of native species across all 44 study sites. Species listed in the order of most sites it was recorded within.

\begin{tabular}{|c|c|c|c|c|c|}
\hline Species & $\begin{array}{r}\text { Count of } \\
\text { sites present } \\
\text { in }\end{array}$ & $\begin{array}{r}\text { Total tree } \\
\text { count } \\
\text { across } \\
\text { sites }\end{array}$ & $\begin{array}{r}\text { Total } \\
\text { seedling } \\
\text { count across } \\
\text { sites }\end{array}$ & $\begin{array}{r}\text { Average tree } \\
\text { abundance } \\
\text { when present }\end{array}$ & $\begin{array}{r}\text { Average } \\
\text { seedling } \\
\text { abundance } \\
\text { when present }\end{array}$ \\
\hline Pittosporum tenuifolium & 41 & 327 & 963 & 7.98 & 23.49 \\
\hline Pittosporum eugenioides & 33 & 138 & 67 & 4.18 & 2.03 \\
\hline Coprosma robusta & 32 & 117 & 2048 & 3.66 & 64.00 \\
\hline Griselinia littoralis & 32 & 137 & 1819 & 4.28 & 56.84 \\
\hline Cordyline australis & 30 & 339 & 16 & 11.30 & 0.53 \\
\hline $\begin{array}{l}\text { Melicytus ramiflorus subsp. } \\
\text { ramiflorus }\end{array}$ & 24 & 134 & 2692 & 5.58 & 112.17 \\
\hline Coprosma rotundifolia & 22 & 8 & 426 & 0.36 & 19.36 \\
\hline Muehlenbeckia australis & 22 & $\mathrm{O}$ & 386 & 0.00 & 17.55 \\
\hline Podocarpus totara var. totara & 22 & 47 & 98 & 2.14 & 4.45 \\
\hline Myrsine australis & 20 & 47 & 180 & 2.35 & 9.00 \\
\hline Kunzea robusta & 18 & 98 & 47 & 5.44 & 2.61 \\
\hline Aristotelia serrata & 17 & 53 & 66 & 3.12 & 3.88 \\
\hline Dacrycarpus dacrydioides & 17 & 24 & 813 & 1.41 & 47.82 \\
\hline Coprosma grandifolia & 16 & 12 & 439 & 0.75 & 27.44 \\
\hline Myoporum laetum & 16 & 143 & 31 & 8.94 & 1.94 \\
\hline Sophora microphylla & 14 & 13 & 410 & 0.93 & 29.29 \\
\hline Dodonaea viscosa & 12 & 51 & 1345 & 4.25 & 112.08 \\
\hline Hoheria angustifolia & 12 & 63 & 775 & 5.25 & 64.58 \\
\hline $\begin{array}{l}\text { Plagianthus regius subsp. } \\
\text { regius }\end{array}$ & 12 & 95 & o & 7.92 & 0.00 \\
\hline Pseudopanax crassifolius & 12 & 11 & 46 & 0.92 & 3.83 \\
\hline Coprosma areolata & 11 & $\mathrm{O}$ & 140 & 0.00 & 12.73 \\
\hline Coprosma lucida & 11 & 13 & 183 & 1.18 & 16.64 \\
\hline $\begin{array}{l}\text { Coprosma propinqua } \times \\
\text { robusta }\end{array}$ & 11 & $\mathrm{O}$ & 139 & 0.00 & 12.64 \\
\hline Coprosma species & 11 & $\mathrm{O}$ & 1276 & 0.00 & 116.00 \\
\hline Parsonsia heterophylla & 11 & O & 959 & 0.00 & 87.18 \\
\hline Prumnopitys taxifolia & 11 & 3 & 13 & 0.27 & 1.18 \\
\hline Pseudopanax arboreus & 11 & 26 & 114 & 2.36 & 10.36 \\
\hline Coprosma repens & 10 & 63 & 31 & 6.30 & 3.10 \\
\hline Veronica salicifolia & 10 & 36 & $\mathrm{O}$ & 3.60 & 0.00 \\
\hline Elaeocarpus hookerianus & 9 & 2 & 66 & 0.22 & 7.33 \\
\hline $\begin{array}{l}\text { Leptospermum scoparium var. } \\
\text { scoparium }\end{array}$ & 9 & 46 & $\mathrm{O}$ & 5.11 & 0.00 \\
\hline Olearia paniculata & 9 & 13 & 3 & 1.44 & 0.33 \\
\hline $\begin{array}{l}\text { Piper excelsum subsp. } \\
\text { excelsum }\end{array}$ & 9 & 22 & 1132 & 2.44 & 125.78 \\
\hline Asplenium oblongifolium & 8 & $\mathrm{O}$ & 132 & 0.00 & 16.50 \\
\hline
\end{tabular}


Pseudopanax colensoi var. colensoi

Pseudopanax crassifolius $x$ lessonii

Carpodetus serratus

Coprosma rhamnoides

Fuchsia excorticata

Hoheria populnea

Hoheria sexstylosa

Pittosporum crassifolium

Pteridium esculentum

Coprosma propinqua var. propinqua

Corynocarpus laevigatus

Pennantia corymbosa

Pseudopanax laetus

Alectryon excelsus subsp. excelsus

Asplenium flaccidum

Asplenium gracillimum

Brachyglottis repanda

Coprosma crassifolia

Myrsine divaricata

Olearia solandri

Pittosporum ralphii

Asplenium appendiculatum subsp. appendiculatum

Lomaria discolor

Parablechnum novae

zelandiae

Dysoxylum spectabile

Olearia arborescens

Pseudopanax colensoi var.

ternatus

Pteris tremula

Coprosma rigida

Elaeocarpus dentatus var.

dentatus

Hedycarya arborea

Hoheria glabrata

Melicope simplex

Melicope ternata

Fuscospora fusca

Olearia avicenniifolia

Passiflora tetrandra

Prumnopitys ferruginea

Pseudopanax ferox

Sophora tetraptera

Adiantum aethiopicum

Clematis paniculata

8

O

41

56

24

70

80

27

316

148

O

69

O

22

20

431

10

22

78

49

5

14

3

5

11

31

187

18

1

31

5

32

1

22

24

2

17

0

O

2

354

3

O

38

4

30
0.00

O. 13

0.00

0.29

0.00

2.00

1.29

1.71

15.00

0.00

7.17

1.83

0.00

0.33

0.20

0.00

0.00

0.80

0.00

0.00

4.20

0.60

0.00

0.00

0.00

1.00

0.25

3.25

0.00

1.00

0.00

1.00

0.00

0.00

1.00

0.67

0.00

0.00

0.33

0.67

2.00

0.00

0.00
5.13

7.00

3.00

10.00

11.43

3.86

45.14

21.14

0.00

9.86

0.00

3.67

3.33

71.83

2.00

4.40

15.60

9.80

1.00

2.80

0.60

1.00

2.75

7.75

46.75

4.50

0.25

7.75

1.25

10.67

0.33

7.33

8.00

0.67

5.67

0.00

0.67

118.00

1.00

0.00

12.67

2.00

15.00 


\begin{tabular}{|c|c|c|c|c|c|}
\hline Coprosma virescens & 2 & 2 & 11 & 1.00 & 5.50 \\
\hline Cyathea dealbata & 2 & $\mathrm{O}$ & 3 & 0.00 & 1.50 \\
\hline Cyathea medullaris & 2 & o & 6 & 0.00 & 3.00 \\
\hline Cyathea smithii & 2 & 3 & 6 & 1.50 & 3.00 \\
\hline $\begin{array}{l}\text { Geniostoma ligustrifolium } \\
\text { var. ligustrifolium }\end{array}$ & 2 & o & 17 & 0.00 & 8.50 \\
\hline Veronica parviflora & 2 & 6 & $\mathrm{O}$ & 3.00 & 0.00 \\
\hline Histiopteris incisa & 2 & $\mathrm{O}$ & 12 & 0.00 & 6.00 \\
\hline Hypolepis ambigua & 2 & 0 & 4 & 0.00 & 2.00 \\
\hline Knightia excelsa & 2 & $\mathrm{O}$ & 8 & 0.00 & 4.00 \\
\hline Melicytus lanceolatus & 2 & 1 & 5 & 0.50 & 2.50 \\
\hline $\begin{array}{l}\text { Polystichum neozelandicum } \\
\text { subsp. neozelandicum }\end{array}$ & 2 & $\mathrm{O}$ & 36 & 0.00 & 18.00 \\
\hline Pseudopanax lessonii & 2 & 1 & 1 & 0.50 & 0.50 \\
\hline Rhopalostylis sapida & 2 & O & 12 & 0.00 & 6.00 \\
\hline Schefflera digitata & 2 & 2 & 0 & 1.00 & 0.00 \\
\hline Sophora chathamica & 2 & 2 & 21 & 1.00 & 10.50 \\
\hline Sophora molloyi & 2 & 3 & 1 & 1.50 & 0.50 \\
\hline Streblus heterophyllus & 2 & 1 & 272 & 0.50 & 136.00 \\
\hline Vitex lucens & 2 & 7 & 1 & 3.50 & 0.50 \\
\hline Beilschmiedia tawa & 1 & o & 2 & 0.00 & 2.00 \\
\hline Coprosma linariifolia & 1 & 2 & 16 & 2.00 & 16.00 \\
\hline Coprosma obconica & 1 & O & 19 & 0.00 & 19.00 \\
\hline Dacrydium cupressinum & 1 & o & 1 & 0.00 & 1.00 \\
\hline Freycinetia banksii & 1 & $\mathrm{O}$ & 2 & 0.00 & 2.00 \\
\hline Veronica strictissima & 1 & 2 & $\mathrm{O}$ & 2.00 & 0.00 \\
\hline Parapolystichum glabellum & 1 & $\mathrm{O}$ & 1 & 0.00 & 1.00 \\
\hline Lophomyrtus obcordata & 1 & 1 & 95 & 1.00 & 95.00 \\
\hline Melicytus micranthus & 1 & $\mathrm{O}$ & 3 & 0.00 & 3.00 \\
\hline Metrosideros excelsa & 1 & 0 & 0 & 0.00 & 0.00 \\
\hline Metrosideros robusta & 1 & $\mathrm{O}$ & 1 & 0.00 & 1.00 \\
\hline $\begin{array}{l}\text { Muehlenbeckia complexa var. } \\
\text { complexa }\end{array}$ & 1 & o & 4 & 0.00 & 4.00 \\
\hline Fuscospora cliffortioides & 1 & 3 & $\mathrm{O}$ & 3.00 & 0.00 \\
\hline Olearia odorata & 1 & O & 2 & 0.00 & 2.00 \\
\hline Olearia traversiorum & 1 & 6 & $\mathrm{O}$ & 6.00 & 0.00 \\
\hline Pyrrosia elaeagnifolia & 1 & $\mathrm{O}$ & 60 & 0.00 & 60.00 \\
\hline Raukaua edgerleyi & 1 & $\mathrm{O}$ & $\mathrm{O}$ & 0.00 & 0.00 \\
\hline Ripogonum scandens & 1 & $\mathrm{O}$ & 4 & 0.00 & 4.00 \\
\hline Rubus australis & 1 & $\mathrm{O}$ & 1 & 0.00 & 1.00 \\
\hline Rubus cissoides & 1 & $\mathrm{O}$ & 7 & 0.00 & 7.00 \\
\hline Urtica ferox & 1 & $\mathrm{O}$ & 3 & 0.00 & 3.00 \\
\hline Veronica speciosa & 1 & O & 0 & 0.00 & 0.00 \\
\hline Weinmannia racemosa & 1 & $\mathrm{O}$ & 1 & 0.00 & 1.00 \\
\hline
\end{tabular}




\section{APPENDiX 3: SPECIES LisT AND TRAit DATA}

Table 18: Compiled plant species list and associated traits used in the analysis for this study. This data is currently being stored on databases at the University of Waikato and will be input into the National Vegetation Survey Database.

\begin{tabular}{|c|c|c|c|c|c|c|c|c|c|c|c|c|}
\hline Species & Scientific Name & Common Name & Plant family & Status & $\begin{array}{l}\text { Structural } \\
\text { Class }\end{array}$ & $\begin{array}{l}\text { Successional } \\
\text { Stage }\end{array}$ & Epiphytic & $\begin{array}{l}\text { Shade } \\
\text { Tolerance }\end{array}$ & $\begin{array}{l}\text { Drought } \\
\text { Tolerance }\end{array}$ & $\begin{array}{l}\text { Primary } \\
\text { Pollinator }\end{array}$ & $\begin{array}{l}\text { Primary } \\
\text { Dispersal }\end{array}$ & $\begin{array}{l}\text { Fruit } \\
\text { Type }\end{array}$ \\
\hline acepse & Acerpseudoplatanus & Sycamore & Sapindaceae & exotic & large tree & early & na & high & moderate & insects & wind & dry \\
\hline adiaet & Adiantum aethiopicum & Maidenhair & Pteridaceae & native & fern & early & na & moderate & moderate & wind & wind & spore \\
\hline albjul & Albizia julibrissin & Mimosa silk tree & Fabaceae & exotic & med tree & pioneer & na & low & high & insects & wind & dry \\
\hline aleexc & Alectryon excelsus subsp. excelsus & $\mathrm{NZ}$ ash titoki & Sapindaceae & native & med tree & mid & na & low & moderate & insects & birds & fruit \\
\hline alnglu & Alnus glutinosa & Common alder & Betulaceae & exotic & med tree & pioneer & na & moderate & moderate & wind & wind & dry \\
\hline ariser & Aristotelia serrata & Wineberry & Elaeocarpaceae & native & small tree & early & na & moderate & low & insects & birds & fruit \\
\hline aspasa & $\begin{array}{l}\text { Asplenium appendiculatum } \\
\text { subsp. appendiculatum }\end{array}$ & Ground spleenwort & Aspleniaceae & native & fern & mid & typical & high & low & wind & wind & spore \\
\hline aspfla & Asplenium flaccidum & Drooping spleenwort & Aspleniaceae & native & fern & mid & typical & high & moderate & wind & wind & spore \\
\hline aspgra & Asplenium gracillimum & Hen \& chicken fern & Aspleniaceae & native & fern & mid & na & high & moderate & wind & wind & spore \\
\hline aspobl & Asplenium oblongifolium & Shining spleenwort & Aspleniaceae & native & fern & mid & occasional & high & moderate & wind & wind & spore \\
\hline aspsca & Asparagus scandens & Climbing asparagus & Asparagacea & exotic & liane & mid & na & high & moderate & insects & birds & fruit \\
\hline astfra & Astelia fragrans & Bush flax & Asteliaceae & native & herb & mid & typical & moderate & moderate & insects & birds & fruit \\
\hline beitaw & Beilschmiedia tawa & Tawa & Lauraceae & native & large tree & late & na & high & low & insects & birds & fruit \\
\hline berdar & Berberis darwinii & Darwins barberry & Berberidaceae & exotic & shrub & mid & na & high & high & insects & birds & fruit \\
\hline betpen & Betula pendula & Silver birch & Betulaceae & exotic & large tree & pioneer & na & low & low & wind & wind & dry \\
\hline bledis & Lomaria discolor & Crown fern & Blechnaceae & native & fern & mid & occasional & high & low & wind & wind & spore \\
\hline bleflu & Cranfillia fluviatilis & Creek fern kiwikiwi & Blechnaceae & native & fern & mid & na & high & low & wind & wind & spore \\
\hline blenov & Parablechnum novae zelandiae & Kiokio/palm leaf fern & Blechnaceae & native & fern & early & na & high & moderate & wind & wind & spore \\
\hline brarep & Brachyglottis repanda & Bushman's friend & Asteraceae & native & small tree & early & ephemeral & moderate & moderate & insects & birds & dry \\
\hline calssr & Calystegia sepium subsp roseata & Pink bindweed & Convolvulaceae & native & liane & early & na & moderate & moderate & insects & water & dry \\
\hline camjap & Camellia Japonica & Common camellia & Theaceae & exotic & shrub & early & na & moderate & high & insects & birds & dry \\
\hline carser & Carpodetus Serratus & Marbleleaf & Rousseaceae & native & small tree & early & na & high & low & insects & birds & fruit \\
\hline chapal & Chamaecytisus palmensis & Tree lucerne & Fabaceae & exotic & small tree & pioneer & na & low & high & insects & birds & dry \\
\hline chrmon & $\begin{array}{l}\text { Chrysanthemoides monilifera } \\
\text { subsp. monilifera }\end{array}$ & Boneseed & Asteraceae & exotic & small tree & pioneer & na & low & high & insects & birds & fruit \\
\hline Clepan & Clematis paniculata & White clematis & Ranunculaceae & native & liane & mid & na & low & low & insects & wind & dry \\
\hline clevit & Clematis vitalba & Old man's beard & Ranunculaceae & exotic & liane & early & na & low & high & wind & wind & dry \\
\hline conarv & Convolvulus arvensis & Convolvulus & Convolvulaceae & exotic & liane & early & na & low & high & insects & birds & fruit \\
\hline copare & Coprosma areolata & Thin leaved cop & Rubiaceae & native & shrub & mid & na & high & low & wind & birds & fruit \\
\hline copcra & Coprosma crassifolia & na & Rubiaceae & native & shrub & early & na & moderate & high & wind & birds & fruit \\
\hline copgra & Coprosma grandifolia & Large leaved cop & Rubiaceae & native & shrub & mid & hemi & high & low & wind & birds & fruit \\
\hline coplin & Coprosma linariifolia & Yellow wood & Rubiaceae & native & small tree & mid & na & high & moderate & wind & birds & fruit \\
\hline copluc & Coprosma lucida & Shining karamu & Rubiaceae & native & shrub & early & na & high & moderate & wind & birds & fruit \\
\hline copobc & Coprosma obconica & na & Rubiaceae & native & shrub & early & na & moderate & moderate & wind & birds & fruit \\
\hline
\end{tabular}




\begin{tabular}{|c|c|c|c|c|c|c|c|c|c|c|c|c|}
\hline coppvp & $\begin{array}{l}\text { Coprosma propinqua var. } \\
\text { propinqua }\end{array}$ & Mingimingi & Rubiaceae & native & small tree & early & na & moderate & high & wind & birds & fruit \\
\hline coppxr & Coprosma propinqua $\times$ robusta & na & Rubiaceae & native & small tree & early & na & moderate & high & wind & birds & fruit \\
\hline coprep & Coprosma repens & Taupata mirror plant & Rubiaceae & native & small tree & early & na & moderate & moderate & wind & birds & fruit \\
\hline coprha & Coprosma rhamnoides & na 1 & Rubiaceae & native & shrub & early & na & high & moderate & wind & birds & fruit \\
\hline coprig & Coprosma rigida & na & Rubiaceae & native & shrub & early & na & moderate & moderate & wind & birds & fruit \\
\hline coprob & Coprosma robusta & Glossy karamu & Rubiaceae & native & small tree & early & hemi & high & moderate & wind & birds & fruit \\
\hline coprot & Coprosma rotundifolia & $\mathrm{nz}$ & Rubiaceae & native & small tree & mid & na & high & low & wind & birds & fruit \\
\hline copspp & Coprosma species & Coprosma & Rubiaceae & native & shrub & pioneer & na & moderate & moderate & wind & birds & fruit \\
\hline copvir & Coprosma virescens & na & Rubiaceae & native & small tree & early & na & moderate & high & wind & birds & fruit \\
\hline coraus & Cordyline australis & Cabbage tree & Asparagacea & native & med tree & early & na & moderate & high & insects & birds & fruit \\
\hline corlae & Corynocarpus laevigatus & Karaka & Corynocarpaceae & native & med tree & early & na & moderate & high & self & birds & fruit \\
\hline cotpan & Cotoneaster pannosus & Silverleaf cotoneaster & Rosaceae & exotic & shrub & pioneer & na & moderate & high & insects & birds & fruit \\
\hline cotsim & Cotoneaster simonsii & Khasia berry & Rosaceae & exotic & shrub & pioneer & na & moderate & high & insects & birds & fruit \\
\hline cramon & Crataegus monogyna & Hawthorn & Rosaceae & exotic & small tree & pioneer & na & moderate & moderate & wind & birds & fruit \\
\hline cupmac & Cupressus macrocarpa & Macrocarpa & Cupressaceae & exotic & large tree & pioneer & na & moderate & moderate & wind & wind & dry \\
\hline cyadea & Cyathea dealbata & Silver fern ponga & Cyatheaceae & native & tree fern & early & na & moderate & moderate & wind & wind & spore \\
\hline cyamed & Cyathea medullaris & Black mamaku & Cyatheaceae & native & tree fern & early & na & low & low & wind & wind & spore \\
\hline cyasmi & Cyathea smithii & Katote soft tree fern & Cyatheaceae & native & tree fern & early & na & high & low & wind & wind & spore \\
\hline cytsco & Cytisus scoparius & Broom & Fabaceae & exotic & shrub & pioneer & na & low & high & insects & ballistic & dry \\
\hline daccup & Dacrydium cupressinum & Red fruit pine & Podocarpaceae & native & large tree & early & ephemeral & high & low & wind & birds & fruit \\
\hline dacdac & Dacrycarpus dacrydioides & $\begin{array}{l}\text { White fruit pine } \\
\text { kahikatea }\end{array}$ & Podocarpaceae & native & large tree & early & na & moderate & low & wind & birds & fruit \\
\hline daplau & Daphne laureola & Spurge laurel & Thymelaeaceae & exotic & shrub & pioneer & na & high & high & insects & birds & fruit \\
\hline dodvis & Dodonaea viscosa & Akeake & Sapindaceae & native & med tree & pioneer & na & low & high & wind & wind & dry \\
\hline dryaff & Dryopteris affinis & na & Dryopteridaceae & exotic & fern & early & na & moderate & high & wind & wind & spore \\
\hline dryfil & Dryopteris filix mas & Male fern & Dryopteridaceae & exotic & fern & early & na & high & high & wind & wind & spore \\
\hline dysspe & Dysoxylum spectabile & Kohekohe nz mahogany & Meliaceae & native & med tree & late & na & high & moderate & insects & birds & fruit \\
\hline eladen & $\begin{array}{l}\text { Elaeocarpus dentatus var. } \\
\text { dentatus }\end{array}$ & Hinau & Elaeocarpaceae & native & med tree & late & na & moderate & moderate & insects & birds & fruit \\
\hline elahoo & Elaeocarpus hookerianus & Pokaka & Elaeocarpaceae & native & med tree & late & na & moderate & low & insects & birds & fruit \\
\hline escrub & Escallonia rubra var. micrantha & Red fruit escallonia & Escalloniaceae & exotic & shrub & early & na & low & low & insects & wind & dry \\
\hline eucreg & Eucalyptus regnans & Giant gum & Myrtaceae & exotic & large tree & pioneer & na & low & moderate & insects & wind & dry \\
\hline $\begin{array}{l}\text { eucreg } \\
\text { euoeur }\end{array}$ & Euomvmus europaeus & Spindle tree & Celastraceae & exotic & small tree & early & na & moderate & moderate & insects & birds & fruit \\
\hline freban & Freycinetia banksii & Kiekie & Pandanaceae & native & liane & mid & na & moderate & low & bats & birds & fruit \\
\hline fucexc & Fuchsia excorticata & Tree fuchsia & Onagraceae & native & med tree & mid & na & moderate & low & birds & birds & fruit \\
\hline genlvl & $\begin{array}{l}\text { Geniostoma ligustrifolium var. } \\
\text { ligustrifolium }\end{array}$ & Hangehange & Loganiaceae & native & shrub & mid & ephemeral & high & moderate & insects & birds & dry \\
\hline grilit & Griselinia littoralis & Broadleaf & Griseliniaceae & native & med tree & mid & hemi & moderate & high & insects & birds & fruit \\
\hline hebpar & Veronica parviflora & Hebe & Plantaginaceae & native & shrub & early & na & low & moderate & insects & wind & dry \\
\hline hebsal & Veronica salicifolia & Koromiko & Plantaginaceae & native & shrub & early & na & low & moderate & insects & wind & dry \\
\hline hebsts & Veronica strictissima & Banks peninsula hebe & Plantaginaceae & native & shrub & pioneer & na & low & moderate & insects & wind & dry \\
\hline hedarb & Hedycarya arborea & $\begin{array}{l}\text { Pigeonwood } \\
\text { Piglat }\end{array}$ & Monimiaceae & native & med tree & mid & na & moderate & low & insects & birds & fruit \\
\hline hedhel & Hedera helix & Ivy & Araliaceae & exotic & liane & early & na & moderate & high & insects & birds & fruit \\
\hline hisinc & Histiopteris incisa & Waterfern & Dennstaedtiaceae & native & fern & early & na & high & low & wind & wind & spore \\
\hline hohang & Hoheria angustifolia & $\begin{array}{l}\text { Narrow leaved lacebark } \\
\text { houhere }\end{array}$ & Malvaceae & native & med tree & early & na & moderate & high & insects & wind & dry \\
\hline hohgla & Hoheria glabrata & Mountain lacebark & Malvaceae & native & small tree & early & na & low & moderate & insects & wind & dry \\
\hline hohpop & Hoheria populnea & Lacebark & Malvaceae & native & small tree & early & na & moderate & high & insects & wind & dry \\
\hline hohsex & Hoheria sexstylosa & Lacebark & Malvaceae & native & med tree & early & na & low & high & insects & wind & dry \\
\hline hypamb & Hypolepis ambigua & na & Dennstaedtiaceae & native & fern & early & na & low & moderate & wind & wind & spore \\
\hline ileagu & Ilex aquifolium & Holly & Aquifoliaceae & exotic & med tree & early & na & moderate & low & insects & birds & fruit \\
\hline
\end{tabular}




\begin{tabular}{|c|c|c|c|c|c|c|c|c|c|c|c|c|}
\hline ipoind & Ipomoea indica & Blue morning glory & Convolvulaceae & exotic & liane & pioneer & na & low & moderate & insects & vegetative & dry \\
\hline jacmim & Jacaranda mimosaefolia & Jacaranda & Bignoniaceae & exotic & med tree & early & na & low & moderate & insects & wind & dry \\
\hline kniexc & Knightia excelsa & $\begin{array}{l}\text { Rewarewa, NZ } \\
\text { honeysuckle }\end{array}$ & Proteaceae & native & large tree & mid & na & low & moderate & insects & wind & dry \\
\hline kunrob & Kunzea robusta & Kanuka & Myrtaceae & native & large tree & pioneer & ephemeral & low & high & insects & wind & dry \\
\hline lasgla & Parapolystichum glabellum & Smooth shield fern & Dryopteridaceae & native & fern & late & na & high & moderate & wind & wind & spore \\
\hline launob & Laurus nobilis & Baytree & Lauraceae & exotic & small tree & pioneer & na & low & high & insects & birds & fruit \\
\hline lepsco & $\begin{array}{l}\text { Leptospermum scoparium var. } \\
\text { scoparium }\end{array}$ & Manuka & Myrtaceae & native & small tree & pioneer & ephemeral & low & high & insects & wind & dry \\
\hline ligluc & Ligustrum lucidum & Tree privet & Oleaceae & exotic & med tree & pioneer & na & moderate & moderate & insects & birds & fruit \\
\hline ligsin & Ligustrum sinense & Chinese privet & Oleaceae & exotic & small tree & pioneer & na & high & moderate & insects & birds & fruit \\
\hline lonjap & Lonicera japonica & Japanese honeysuckle & Caprifoliaceae & exotic & liane & early & na & moderate & moderate & insects & birds & fruit \\
\hline lopobc & Lophomyrtus obcordata & NZ myrtle rohutu & Myrtaceae & native & shrub & early & na & moderate & moderate & insects & birds & fruit \\
\hline luparb & Lupinus arboreus & Tree lupin & Fabaceae & exotic & shrub & pioneer & na & low & high & insects & ballistic & dry \\
\hline malxdo & Malus $x$ domestica & Apple & Rosaceae & exotic & small tree & early & na & high & low & insects & birds & fruit \\
\hline meldec & Melanoselinum decipiens & Parsnip palm & Apiaceae & exotic & herb & mid & na & moderate & moderate & insects & birds & fruit \\
\hline mellan & Melicytus lanceolatus & Narrow leaved mahoe & Violaceae & native & small tree & mid & na & moderate & moderate & insects & birds & fruit \\
\hline melmic & Melicytus micranthus & Swamp mahoe & Violaceae & native & shrub & early & na & high & low & insects & birds & fruit \\
\hline melram & $\begin{array}{l}\text { Melicytus ramiflorus subsp. } \\
\text { ramiflorus }\end{array}$ & Mahoe & Violaceae & native & med tree & early & ephemeral & moderate & moderate & insects & birds & fruit \\
\hline melsim & Melicope simplex & Poataniwha & Rutaceae & native & shrub & mid & na & moderate & moderate & insects & ballistic & dry \\
\hline melter & Melicope ternata & Wharangi & Rutaceae & native & small tree & mid & na & moderate & moderate & insects & ballistic & dry \\
\hline metexc & Metrosideros excelsa & Pohutukawa & Myrtaceae & native & med tree & pioneer & na & low & high & insects & wind & dry \\
\hline metful & Metrosideros fulgens & Scarlet rata & Myrtaceae & native & liane & mid & na & moderate & low & insects & wind & dry \\
\hline metrob & Metrosideros robusta & Northern rata & Myrtaceae & native & large tree & late & hemi & low & high & insects & wind & dry \\
\hline mueaus & Muehlenbeckia australis & $\begin{array}{l}\text { Large leaved } \\
\text { muehlenbeckia } \\
\text { pohuehue }\end{array}$ & Polygonaceae & native & liane & early & na & moderate & moderate & insects & birds & fruit \\
\hline muecom & $\begin{array}{l}\text { Muehlenbeckia complexa var. } \\
\text { complexa }\end{array}$ & Small leaved pohuehue & Polygonaceae & native & liane & early & na & low & high & insects & birds & fruit \\
\hline myolae & Myoporum laetum & Ngaio & Scrophulariaceae & native & med tree & early & na & moderate & high & insects & birds & fruit \\
\hline myraus & Myrsine australis & Red mapou & Primulaceae & native & small tree & early & ephemeral & moderate & moderate & insects & birds & fruit \\
\hline myrdiv & Myrsine divaricata & $\begin{array}{l}\text { Weeping matipo/ } \\
\text { mapou }\end{array}$ & Primulaceae & native & shrub & early & na & moderate & moderate & insects & birds & fruit \\
\hline notcli & Fuscospora cliffortioides & Mountain beech & Mothofagaceae & native & large tree & mid & na & low & high & wind & wind & dry \\
\hline notfus & Fuscospora fusca & Red beech & Nothofagaceae & native & large tree & mid & na & low & moderate & insects & wind & dry \\
\hline olearb & Olearia arborescens & Common tree daisy & Asteraceae & native & shrub & early & na & low & moderate & insects & wind & dry \\
\hline oleavi & Olearia avicenniifolia & Mountain akeake & Asteraceae & native & small tree & pioneer & na & low & high & insects & wind & dry \\
\hline oleeur & Olea europaea subsp. europaea & European olive & Oleaceae & exotic & small tree & early & na & low & high & insects & wind & fruit \\
\hline oleodo & Olearia odorata & Scented tree daisy & Asteraceae & native & shrub & early & na & low & high & insects & wind & dry \\
\hline olepan & Olearia paniculata & Golden akeake akiraho & Asteraceae & native & small tree & early & na & low & high & insects & wind & dry \\
\hline olesol & Olearia solandri & Coastal tree daisy & Asteraceae & native & shrub & early & na & low & high & insects & wind & dry \\
\hline oletra & Olearia traversiorum & $\begin{array}{l}\text { Chatham island akeake/ } \\
\text { tree daisy }\end{array}$ & Asteraceae & native & med tree & pioneer & na & low & high & insects & wind & dry \\
\hline parhet & Parsonsia heterophylla & NZ jasmine & Apocynaceae & native & liane & mid & na & high & moderate & insects & ballistic & dry \\
\hline parlop & Paraserianthes lophantha & Brush wattle & Fabaceae & exotic & small tree & pioneer & na & low & moderate & insects & birds & dry \\
\hline pastet & Passiflora tetrandra & $\mathrm{NZ}$ passionfruit & Passifloraceae & native & liane & mid & na & low & & insects & birds & fruit \\
\hline pastvm & $\begin{array}{l}\text { Passiflora tripartita var. } \\
\text { mollissima }\end{array}$ & Banana passionfruit & Passifloraceae & exotic & liane & early & na & moderate & moderate & insects & birds & fruit \\
\hline pencor & Pennantia corymbosa & Kaikomako & Pennantiaceae & native & small tree & early & na & moderate & moderate & insects & birds & fruit \\
\hline phydiv & $\begin{array}{l}\text { Microsorum pustulatum subsp. } \\
\text { pustulatum }\end{array}$ & Hounds tongue & Polypodiaceae & native & fern & early & typical & high & high & wind & wind & spore \\
\hline
\end{tabular}




\begin{tabular}{|c|c|c|c|c|c|c|c|c|c|c|c|c|}
\hline pinrad & Pinus radiata & Radiata pine & Pinaceae & exotic & large tree & pioneer & na & low & high & wind & wind & dry \\
\hline pipexc & Piper excelsum subsp. excelsum & Kawakawa & Piperaceae & native & small tree & early & ephemeral & high & moderate & insects & birds & fruit \\
\hline pitcrf & Pittosporum crassifolium & Karo & Pittosporaceae & native & small tree & early & na & moderate & high & insects & birds & dry \\
\hline piteug & Pittosporum eugenioides & Lemonwood tarata & Pittosporaceae & native & med tree & early & na & moderate & moderate & insects & birds & fruit \\
\hline pitral & Pittosporum ralphii & Karo & Pittosporaceae & native & small tree & pioneer & na & moderate & high & insects & birds & fruit \\
\hline pitten & Pittosporum tenuifolium & Black matipo Kohuhu & Pittosporaceae & native & small tree & early & na & moderate & high & insects & birds & dry \\
\hline plarsr & Plagianthus regius subsp. regius & Ribbonwood & Malvaceae & native & med tree & early & na & moderate & moderate & insects & birds & fruit \\
\hline podcun & Podocarpus laetus & Mountain/ hall's totora & Podocarpaceae & native & med tree & mid & na & moderate & high & wind & birds & fruit \\
\hline podtot & Podocarpus totara var. totara & Totara & Podocarpaceae & native & large tree & mid & na & moderate & high & wind & birds & fruit \\
\hline polneo & $\begin{array}{l}\text { Polystichum neozelandicum } \\
\text { subsp. neozelandicum }\end{array}$ & na & Dryopteridaceae & native & fern & mid & na & moderate & high & wind & wind & spore \\
\hline polves & Polystichum vestitum & Prickly shield fern & Dryopteridaceae & native & fern & mid & na & high & low & wind & wind & spore \\
\hline pruavi & Prunus avium & Sweet cherry & Rosaceae & exotic & med tree & pioneer & na & moderate & moderate & insects & birds & fruit \\
\hline prucam & Prunus campanulata & Taiwan cherry & Rosaceae & exotic & small tree & pioneer & na & moderate & moderate & insects & birds & fruit \\
\hline prucer & Prunus cerasifera & Cherry plum & Rosaceae & exotic & small tree & pioneer & na & moderate & moderate & insects & birds & fruit \\
\hline prufer & Prumnopitys ferruginea & Miro & Podocarpaceae & native & large tree & late & ephemeral & high & low & wind & birds & fruit \\
\hline prulau & Prunus laurocerasus & Cherry laurel & Rosaceae & exotic & small tree & pioneer & na & moderate & moderate & insects & birds & fruit \\
\hline pruser & Prunus serrulata & Japanese hill cherry & Rosaceae & exotic & med tree & pioneer & na & moderate & moderate & insects & birds & fruit \\
\hline prutax & Prumnopitys taxifolia & Matai & Podocarpaceae & native & large tree & mid & na & moderate & high & insects & birds & fruit \\
\hline psearb & Pseudopanax arboreus & Fivefinger & Araliaceae & native & small tree & early & hemi & moderate & moderate & insects & birds & fruit \\
\hline psecra & Pseudopanax crassifolius & Lancewood & Araliaceae & native & med tree & mid & ephemeral & moderate & moderate & insects & birds & fruit \\
\hline psecve & $\begin{array}{l}\text { Pseudopanax colensoi var. } \\
\text { colensoi }\end{array}$ & Mountain five finger & Araliaceae & native & small tree & mid & na & moderate & low & insects & birds & fruit \\
\hline psecvt & $\begin{array}{l}\text { Pseudopanax colensoi var. } \\
\text { ternatus }\end{array}$ & na & Araliaceae & native & small tree & early & ephemeral & moderate & moderate & insects & birds & fruit \\
\hline psecxl & $\begin{array}{l}\text { Pseudopanax crassifolius } x \\
\text { lessonii }\end{array}$ & na & Araliaceae & native & med tree & early & na & moderate & moderate & insects & birds & fruit \\
\hline psefer & Pseudopanax ferox & Fierce lancewood & Araliaceae & native & small tree & mid & na & moderate & moderate & insects & birds & fruit \\
\hline pselae & Pseudopanax laetus & na & Araliaceae & native & small tree & early & typical & moderate & low & insects & birds & fruit \\
\hline pseles & Pseudopanax lessonii & Houpara & Araliaceae & native & small tree & early & na & low & moderate & insects & birds & fruit \\
\hline pteesc & Pteridium esculentum & Bracken & Dennstaedtiaceae & native & fern & early & na & low & high & wind & wind & spore \\
\hline ptetre & Pteris tremula & Shaking brake & Pteridaceae & native & fern & early & na & moderate & moderate & wind & wind & spore \\
\hline pyrele & Pyrrosia elaeagnifolia & Leather leaf fern & Polypodiaceae & native & fern & mid & typical & low & high & wind & wind & spore \\
\hline querob & Quercus robur & European oak & Fagaceae & exotic & large tree & early & na & low & moderate & insects & birds & dry \\
\hline rauedg & Raukaua edgerleyi & Raukawa & Araliaceae & native & med tree & early & hemi & moderate & low & insects & birds & fruit \\
\hline rhaala & Rhamnus alaternus & Evergreen buckthorn & Rhamnaceae & exotic & shrub & pioneer & na & high & high & insects & birds & fruit \\
\hline rhosap & Rhopalostylis sapida & Nikau palm & Arecaceae & native & med tree & mid & na & moderate & moderate & insects & birds & fruit \\
\hline ribuva & Ribes uva crispa & Gooseberry & Grossulariaceae & exotic & shrub & early & na & moderate & moderate & insects & birds & fruit \\
\hline ripsca & Ripogonum scandens & Supple jack & Ripogonaceae & native & liane & mid & na & low & low & insects & birds & fruit \\
\hline robpse & Robinia pseudoacacia & Black locust & Fabaceae & exotic & large tree & pioneer & na & low & high & insects & vegetative & dry \\
\hline rubaus & Rubus australis & Bush lawyer & Rosaceae & native & liane & mid & na & high & low & insects & birds & fruit \\
\hline rubcis & Rubus cissoides & Bush lawyer & Rosaceae & native & liane & mid & na & moderate & moderate & insects & birds & fruit \\
\hline rubfru & Rubus fruticosus agg & Blackberry & Rosaceae & exotic & liane & pioneer & na & low & high & insects & birds & fruit \\
\hline salcin & Salix cinerea & Grey willow & Salicaceae & exotic & small tree & pioneer & na & low & low & insects & wind & dry \\
\hline samnig & Sambucus nigra & Elderberry elderflower & Adoxaceae & exotic & small tree & pioneer & na & low & low & insects & birds & fruit \\
\hline schdig & Schefflera digitata & Pate seven finger & Araliaceae & native & small tree & early & na & moderate & low & insects & birds & fruit \\
\hline sopcha & Sophora chathamica & Coastal kowhai & Fabaceae & native & med tree & early & na & moderate & high & birds & wind & dry \\
\hline sopmic & Sophora microphylla & Weeping kowhai & Fabaceae & native & large tree & pioneer & na & moderate & high & birds & wind & dry \\
\hline sopmol & Sophora molloyi & Cook strait kowhai & Fabaceae & native & shrub & pioneer & na & low & high & insects & wind & dry \\
\hline soptet & Sophora tetraptera & Large leaved kowhai & Fabaceae & native & med tree & pioneer & na & moderate & high & insects & wind & dry \\
\hline strhet & Streblus heterophyllus & Turepo small leaved & Moraceae & native & small tree & mid & na & moderate & low & insects & birds & fruit \\
\hline
\end{tabular}




\begin{tabular}{|c|c|c|c|c|c|c|c|c|c|c|c|c|}
\hline taxbac & Taxus baccata & Yew & Taxaceae & exotic & med tree & mid & na & high & moderate & wind & birds & fruit \\
\hline uleeur & Ulex europaeus & Gorse & Fabaceae & exotic & shrub & pioneer & na & low & & insects & ballistic & dry \\
\hline urtfer & Urtica ferox & Ongaonga & Urticaceae & native & shrub & early & na & moderate & moderate & wind & wind & dry \\
\hline vacvic & Vaccinium vitis idaea & Ligonberry & Ericaceae & exotic & shrub & mid & na & moderate & high & insects & birds & fruit \\
\hline verspe & Veronica speciosa & Titirangi & Plantaginaceae & native & shrub & early & na & & high & insects & wind & dry \\
\hline vitluc & Vitex lucens & Puriri ${ }^{\circ}$ & Lamiaceae & native & med tree & mid & na & moderate & moderate & insects & birds & fruit \\
\hline weirac & Weinmannia racemosa & Kamahi & Cunoniaceae & native & large tree & late & hemi & moderate & low & insects & wind & dry \\
\hline
\end{tabular}

Table 19: Descriptions used to compile trait categories.

\begin{tabular}{|c|c|}
\hline Trait Category & Description \\
\hline Structural Class & $\begin{array}{l}\text { The plant form of each species. Includes: } \\
\text { - Trees (woody species with typically one main stem or trunk with lateral branches at some distance from the ground. Includes small }<10 \mathrm{~m} \text {, } \\
\text { - } \quad \text { Shedium 10-20m and large } 20+\mathrm{m} \text { size classes) } \\
\text { - Ferns (vascular ground plant with fronds) } \\
\text { - } \quad \text { Liane (woody climbing plant that hangs from trees) } \\
\text { - } \quad \text { Epiphyte (a plant that grows on another plant) }\end{array}$ \\
\hline Successional Stage & $\begin{array}{l}\text { The earliest successional stage a species can be planted. Included: } \\
\text { - Pioneer (hardy species which are the first to colonize previously disrupted or damaged ecosystems, beginning a chain of ecological succession that } \\
\text { ultimately leads to a more biodiverse steady-state ecosystem.) } \\
\text { - Early (species which colonise habitat consisting of grasses, forbs, shrubs and trees which provide protection. Habitats include weedy areas, } \\
\text { grasslands, pastures, shrubland and young forest) } \\
\text { - Mid (species which inhabit more mature forests. Mid-successional forests have a canopy cover of less than } 70 \text { percent, a canopy and sub-canopy } \\
\text { composed of native species and a shrub layer of native species) } \\
\text { - Late (highly shade tolerant species which establish in mature forests with closed canopies. Usually regenerate under parent plants) }\end{array}$ \\
\hline Primary Pollinator & The dominant pollinator agent for each species \\
\hline Primary Dispersal & The dominant dispersal agent for each species \\
\hline
\end{tabular}


Table 20: Table of coefficients. The $R$-core base package ( $R$ Project, 2019) was used to compute correlations and between variables and associated p-values using Pearson correlation coefficient. Correlation figures are in the top half of the matrix and p-values on the bottom half. Moderate (0.5) and high (0.9) correlations are highlighted. Only continuous variables were included in the correlation analysis.

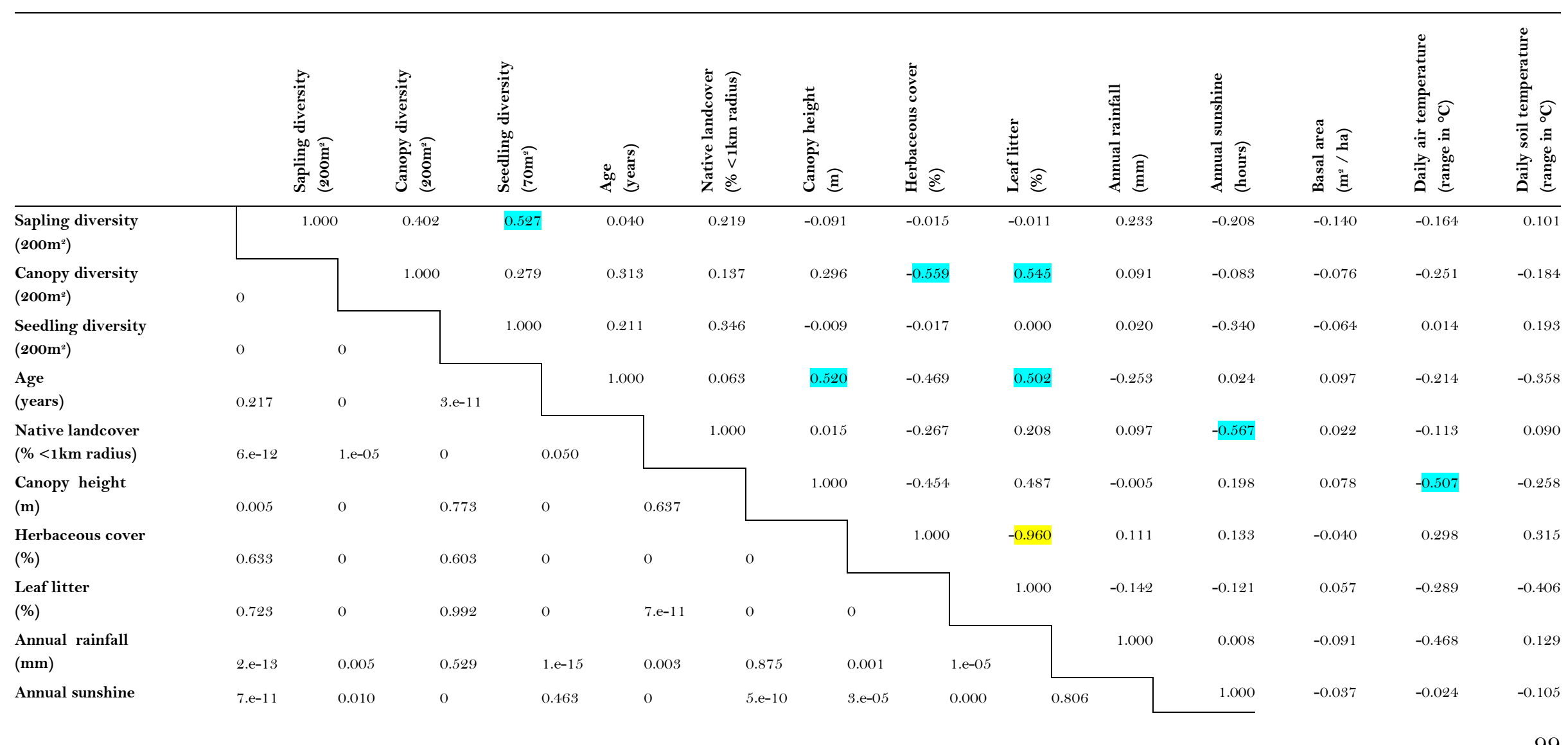


Basta

(m² / ha)

Daily air temperature

(range in ${ }^{\circ} \mathrm{C}$ )

Daily soil temperature

(range in ${ }^{\circ} \mathrm{C}$ )

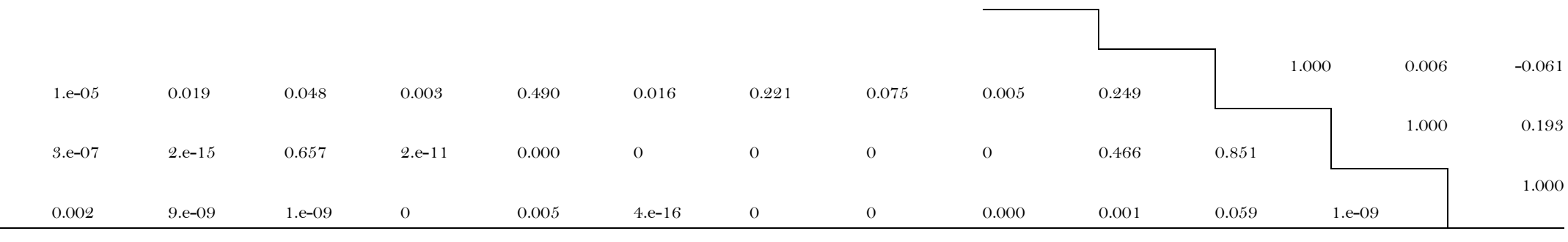

